UNIVERSIDADE DE SÃO PAULO

FACULDADE DE ECONOMIA, ADMINISTRAÇÃO E CONTABILIDADE DEPARTAMENTO DE ECONOMIA

Raul Antonio Cristóvão dos Santos

Eficiência Portuária no Brasil

São Paulo

2007 
Raul Antonio Cristóvão dos Santos

\title{
Eficiência Portuária no Brasil
}

\author{
Dissertação apresentada ao Departamento de \\ Economia como parte dos requisitos para \\ obtenção do título de Mestre em Ciência \\ Econômica.
}

Orientador: Prof. Dr. Eduardo A. Haddad

São Paulo 
AUTORIZO A REPRODUÇÃO E DIVULGAÇÃO TOTAL OU PARCIAL DESTE TRABALHO, POR QUALQUER MEIO CONVENCIONAL OU ELETRÔNICO, PARA FINS DE ESTUDO OU PESQUISA, DESDE QUE CITADA A FONTE.

FICHA CATALOGRÁFICA

Elaborada pela Seção de Processamento Técnico do SBD/FEA/USP

Santos, Raul Antonio Cristóvão dos

Eficiência portuária no Brasil / Raul Antonio Cristóvão dos

Santos. -- São Paulo, 2007.

103 p.

Dissertação (Mestrado) - Universidade de São Paulo, 2007

Bibliografia

1. Comércio exterior 2. Portos 3. Econometria I. Universidade de São Paulo. Faculdade de Economia, Administração e Contabilidade. II. Título.

CDD - 382 


\title{
FOLHA DE APROVAÇÃO
}

Raul Antonio Cristovão dos Santos

Eficiência Portuária no Brasil

\author{
Dissertação apresentada ao Departamento de \\ Economia como parte dos requisitos para \\ obtenção do título de Mestre em Ciência \\ Econômica.
}

Aprovado em:

Banca Examinadora

Prof. Dr.

Instituição:

Assinatura:

Prof. Dr.

Instituição:

Assinatura:

Prof. Dr.

Instituição:

Assinatura: 


\section{AGRADECIMENTOS}

A realização deste trabalho não foi uma tarefa de todo solitária. Algumas pessoas fizeram, intencionalmente ou não, contribuições importantes que gostaria de reconhecer neste espaço. De início, agradeço aos professores dos cursos que assisti, nominalmente, Carlos Eduardo Soares Gonçalves, André Portela, Márcio Nakane, Denisard Cnéio Alves, Danilo Camargo Igliori e Nelson Hideiki Nozoe. Devo agradecer ainda aos professores Carlos Azzoni e Joaquim Guilhoto pelas sugestões que fizeram no exame de qualificação. Dedico um agradecimento especial ao meu orientador Eduardo Haddad, que me acompanha deste a graduação, por me conduzir através destes anos.

A maior parte desta dissertação foi feita na sala $17,1^{\circ}$ andar, FEA II e, ao longo do tempo transcorrido até seu término, tive o prazer de compartilhá-la com uma série de amigos que através de conversas intelectuais e outras nem tanto proporcionaram o ambiente adequado para completar minha tarefa. Foram eles: Edgard Pimentel, Marinho Bertanha, Lucas Mation, Gervásio Ferreira, Lucas Ferraz e Ana Barufi.

Não poderia deixar de agradecer aos meus pais, Raul e Sylvia. É impossível separar todas as contribuições que eles fizeram a minha formação e dizer qual delas está relacionada a presente dissertação. Somente deixo registrado que meus pais são responsáveis por grande parte da pessoa que me tornei e uma parcela desta responsabilidade não foi sua intenção: tamanha é minha admiração por eles que conscientemente permiti que sua influência tivesse efeito sobre mim 


\section{SUMÁRIO}

Resumo

p. vii

Abstract.

p. viii

1. Introdução

p. 09

2. Os portos no comércio internacional brasileiro

p. 19

2.1. Portos: informações gerais

p. 20

2.2. Importância do comércio internacional das UFs brasileiras para os portos.

p. 26

2.3. Importância dos portos para o comércio internacional das UFs brasileiras.

p. 34

2.4. Síntese.

p. 39

3. Revisão de literatura.

p. 41

3.1. Abordagem de fronteira estocástica.

p. 41

3.2. Medidas relativas de eficiência portuária - abordagem DEA.

p. 49

3.3. Medidas relativas de eficiência portuária - abordagem de Blonigen \& Wilson (2006)

p. 51

4. Estimação dos custos logísticos do comércio internacional brasileiro

p. 54

4.1. Metodologia e banco de dados

p. 54

4.2. Resultados...

p. 63

5. Conclusões

p. 77

Bibliografia

p. 82

Apêndice A.1

p. 84

Apêndice A.2

p. 93 


\section{ÍNDICE DE TABELAS}

1.1 - Exportações por via de transporte (\%)

p. 16

1.2 - Importações por via de transporte (\%)

p. 16

2.1 - Movimentação de cargas, por natureza, 2004 (em toneladas)

p. 21

2.2 - Tipos de carga movimentada por porto, 2000 e 2004 (\%).

p. 23

2.3. - Participação dos portos na movimentação total de contêineres no Brasil...

p. 25

4.1 - Modelos probit da probabilidade do porto ser utilizado.

p. 64

4.2. - Impacto das distâncias sobre a probabilidade de escolha dos portos.

p. 68

4.3. - Resultados: medidas de eficiência portuária relativa.

p. 71

A.1.1 - Participação das importações estaduais no total importado por porto de entrada (\%)

p. 89

A.1.1 - Participação das importações estaduais no total importado por porto de entrada (\%), final.

p. 90

A1.2 - Participação das exportações estaduais no total exportado por porto de entrada (\%)

p. 91

A1.2 - Participação das exportações estaduais no total exportado por porto de entrada (\%), final

A.2.1 - Utilização dos portos pelos estados do Brasil, importações, 2002 (\%)....

A.2.2 - Utilização dos portos pelos estados do Brasil, exportações, 2002 (\%)..... 


\section{RESUMO}

A queda das barreiras comerciais artificiais entre os países trouxe destaque às barreiras representadas pelos custos de transporte do comércio internacional. Entre estes, o custo associados à atividade portuária tem sido alvo de atenção especial. Também no Brasil, a percepção de que a eficiência portuária é um fator crítico para a economia ganha força. No entanto, não existem estimativas da contribuição dos portos para a variação dos custos de transporte e da diferença de custos entre os portos. O presente trabalho visa preencher estas lacunas. Através de dados das importações brasileiras do ano de 2002, desenvolvemos um modelo econométrico [baseado em Blonigen \& Wilson (2006)] que permite medir a variação do custo de importar uma mercadoria devido aos portos. O modelo permite-nos ainda ter uma idéia da eficiência relativa entre os portos da amostra, ou seja, em condições semelhantes qual porto oferece o menor custo.

Palavras-chave: Comércio internacional, portos, econometria. 


\begin{abstract}
The fall of artificial trade barriers between the countries highlighted the barriers represented by the transport costs of international trade. Among these, the cost associated with the port activity has received special attention. Also in Brazil, the perception that port efficiency is an important factor to the economy has gained strength. However, there are no estimates of the contribution of ports to the variation of the transport costs and of the difference of cost between the Brazilian ports. The present work aims to fill these gaps. Using data of the Brazilian imports for 2002, we develop an econometric model [based on Blonigen \& Wilson (2006)] that allows us to measure the variation of the cost to import a good due to port. The model allows us to have an idea of the relative efficiency of the ports.
\end{abstract}

Key words: international trade, ports, econometrics. 


\section{CAPÍTULO 1. Introdução}

A queda das barreiras comerciais artificiais entre os países trouxe destaque às barreiras representadas pelos custos de transporte do comércio internacional. Na esteira desta mudança, surgiu uma literatura que tentava avaliar os impactos dos custos de transporte ao comércio e economia dos países. Os trabalhos de Hummels (2001) e Redding e Venables (2001) são exemplos desta literatura. Hummels (2001) desenvolve um modelo para explicar como as firmas escolhem o país em que se instalam e o modal (aéreo ou marítimo) que usam para exportar para os Estados Unidos ${ }^{1}$. No modelo, a escolha baseia-se na minimização do custo total que inclui o custo de produzir a quantidade da mercadoria que será exportada (específico para cada país), o custo de frete e o custo em termos do tempo (em dias) que leva para a mercadoria chegar ao destino.

Esse último termo da função custo é feito dependente de uma taxa de juros e uma taxa de depreciação (ambas diárias). O argumento para justificar a depreciação da mercadoria em trânsito baseia-se na possibilidade dela estragar, ou de danificar-se, ou ainda do desencontro entre o que os consumidores desejam comprar e o que os produtores têm à disposição para vender.

Assim, para cada país é possível determinar qual a escolha ótima de meio de transporte (aéreo ou marítimo) e, em seguida, descobrir qual o melhor país para servir de base exportadora comparando seu custo, já avaliado na escolha ótima de modal. Um dos resultados do modelo de Hummels (2001) é que o transporte aéreo é escolhido quando a economia de tempo que representa em relação ao marítimo supera seu preço mais elevado. Hummels (2001) testa

\footnotetext{
${ }^{1}$ A fixação dos Estados Unidos como único destino das exportações é feita em função da disponibilidade dos dados. Como os EUA é o principal parceiro comercial de muitos outros países, esta hipótese não é tão restritiva.
} 
econometricamente seu modelo através de dois probits: o primeiro para determinar a probabilidade do país exportar um bem $k$ para os Estados Unidos, e o segundo determinando a probabilidade da escolha do modal de transporte condicionado ao país exportar para os Estados Unidos. Os resultados mostram que o aumento do prazo de entrega em um dia diminui a probabilidade de este país exportar para os EUA, em média, de $1 \%$ a 1,5\%. Hummels também mostra que uma viagem marítima de vinte dias equivale a uma tarifa $a d$ valorem de $8 \%$.

Redding e Venables (2001) discutem porque o aumento na integração econômica não está sendo acompanhado de uma movimentação de plantas e firmas para países com salários mais baixos, de modo a reduzir a desigualdade entre os países. Os autores constroem um modelo de geografia econômica em que a decisão de uma firma sobre em qual país instalar-se é afetada pela localização geográfica dele em relação aos mercados consumidores e os fornecedores de insumos. Três equações são deduzidas a partir do modelo para serem usadas em estimações econométricas. A primeira medindo o acesso aos mercados (e fornecedores) de cada país; a segunda mostrando qual o salário que a firma pode pagar em cada país dado seu acesso ao mercado e aos fornecedores; por fim, uma terceira equação para o índice de preços também em função da localização geográfica do país.

Na estimação da segunda equação, Redding e Venables (2001) usam a renda per capita como proxy para os salários industriais. Os resultados, robustos segundo os autores por incluírem outras variáveis que na literatura de crescimento econômico explicam diferenças na renda per capita, mostram que países mais distantes dos mercados consumidores (e dos fornecedores de insumos) terão que pagar salários menores para que as firmas que se instalem neles não tenham prejuízos. 
Entre os custos de transportes associados ao comércio internacional, o custo associado à atividade portuária tem sido alvo de atenção especial. Por exemplo, Clark et al (2004) investigam o impacto de mudanças na eficiência portuária sobre o custo total de transporte no comércio internacional. Os autores estimam um modelo de precificação do transporte marítimo a partir dos dados de taxas pagas nas importações dos EUA trazidas por companhias de transporte marítimo de linha regular ${ }^{2}$. No modelo, a taxa de transporte marítimo por unidade de peso é igual ao custo marginal vezes um mark-up.

O custo marginal é uma função de dummies para o tipo de mercadoria e distrito de destino nos EUA, do valor do produto por unidade de peso transportada, da porcentagem do produto transportada que é conteinerizada, do volume total de produtos importados pelos EUA de cada país estrangeiro, da distância entre o porto estrangeiro e o distrito alfandegário nos EUA e uma variável que mede o desequilíbrio no comércio entre os EUA e o país estrangeiro. Também são incluídas medidas alternativas para a eficiência do porto estrangeiro, incluindo o índice do relatório anual Global Competitiveness Report (GCR, daqui em diante) publicado pelo World Economic Forum desde 1979. O GCR mede a capacidade dos países em prover altos níveis de prosperidade para seus cidadãos. Uma das medidas apresentadas é um índice de qualidade da infra-estrutura portuária. Este índice é calculado a partir de uma pesquisa feita com usuários que respondem à pergunta: "port facilities and inland waterways in your country are...”; as respostas são enumeradas de 1 a 7, sendo 1 equivalente a subdesenvolvidos e 7, tão desenvolvidos quanto os melhores do mundo. O mark-up depende da existência de acordos de fixação de preço e acordos de cooperação entre o distrito nos EUA e o país estrangeiro.

\footnotetext{
${ }^{2}$ No transporte marítimo de linha regular o itinerário é conhecido e repetitivo, as cargas transportadas são heterogêneas (tipo carga geral), conteinerizadas ou soltas. As tarifas são estabelecidas unilateralmente pelas companhias ou por conferências de fretes, ou seja, acordos entre um grupo de companhias que prestam serviço em uma rota ou área geográfica de modo a estabelecerem fretes e outras condições uniformemente [Vieira (2003), pp. 37-38].
} 
A estimação é feita usando variáveis instrumentais para corrigir a endogeneidade da variável de volume; o instrumento utilizado é o PIB do país estrangeiro. A amostra cobre os anos de 1996-2000, sendo realizadas regressões individuais para cada ano. Os coeficientes estimados para as variáveis que explicam o custo marginal foram, em geral, significantes e tiveram os sinais esperados. Já os coeficientes estimados para as variáveis explicativas do mark-up não foram significantes ou, até quando foram, tiveram sinal contrário ao esperado. Em particular, destacamos o resultado para a variável de eficiência portuária medida pelo índice do GCR para o ano 2000; os autores mencionam explicitamente o Brasil e afirmam que se a eficiência portuária brasileira chegasse ao patamar da França ou Suécia o custo de transporte marítimo reduzir-se-ia por mais de $15 \%$.

Por fim, Clark et al (2004) estudam a relação do custo de transporte marítimo e comércio internacional. Os autores constroem quatro índices de custos de transporte marítimo utilizando os erros estimados de quatro especificações distintas da equação dos determinantes do custo de transporte marítimo. Para cada país, os índices são construídos como a média dos erros estimados. Os índices são inseridos na estimação de um modelo gravitacional. Para a amostra, os resultados mostram que se um país sair do $25^{\circ}$ para o $75^{\circ}$ percentil de custo de transporte marítimo (aumento do custo) o comércio bilateral cai aproximadamente 22\%.

Também no Brasil, a percepção de que a eficiência portuária é um fator crítico para o comércio internacional ganha força. Algumas informações mostram a dimensão do problema no país. Os problemas associados à atividade portuária no Brasil fazem parte do chamado “custo Brasil”, isto é, o conjunto de fatores desfavoráveis à competitividade das empresas no Brasil, que independem delas próprias. Uma amostra disto é a estimativa da Associação 
Nacional dos Usuários de Transportes de Carga (ANUT) de que os atrasos no embarque e desembarque nos portos, causados, entre outros, pelo número insuficiente de berços e contêineres e pelo tamanho inadequado dos berços, custou ao Brasil US\$ 1,2 bilhões em 2004.

Outro exemplo é o já mencionado índice de qualidade da infra-estrutura portuária do GCP. O Gráfico 1.1 apresenta alguns dos resultados para países selecionados e ano de 2006. A barra horizontal diz respeito à média mundial e os números antes do nome dos países, à posição ocupada por eles em um ranking deste índice. O país líder em qualidade da infra-estrutura portuária é Singapura, seguido por Holanda, Hong Kong e Alemanha. Os Estados Unidos aparecem na $15^{\mathrm{a}}$ posição. O Brasil ocupa a $88^{\mathrm{a}}$ posição, entre um total de 125 países, atrás de outros países em desenvolvimento como a Coréia do Sul (27ª posição) e, na América Latina,

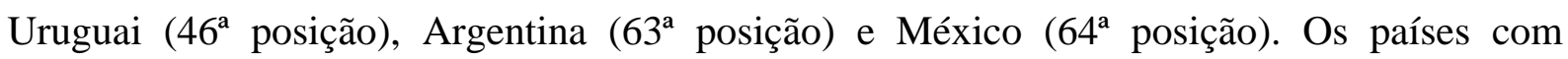
classificação pior do que o Brasil são em sua maioria do continente africano; alguns são da América do Sul e leste europeu. 


\section{Gráfico 1.1. Índice de qualidade de infra-estrutura portuária}

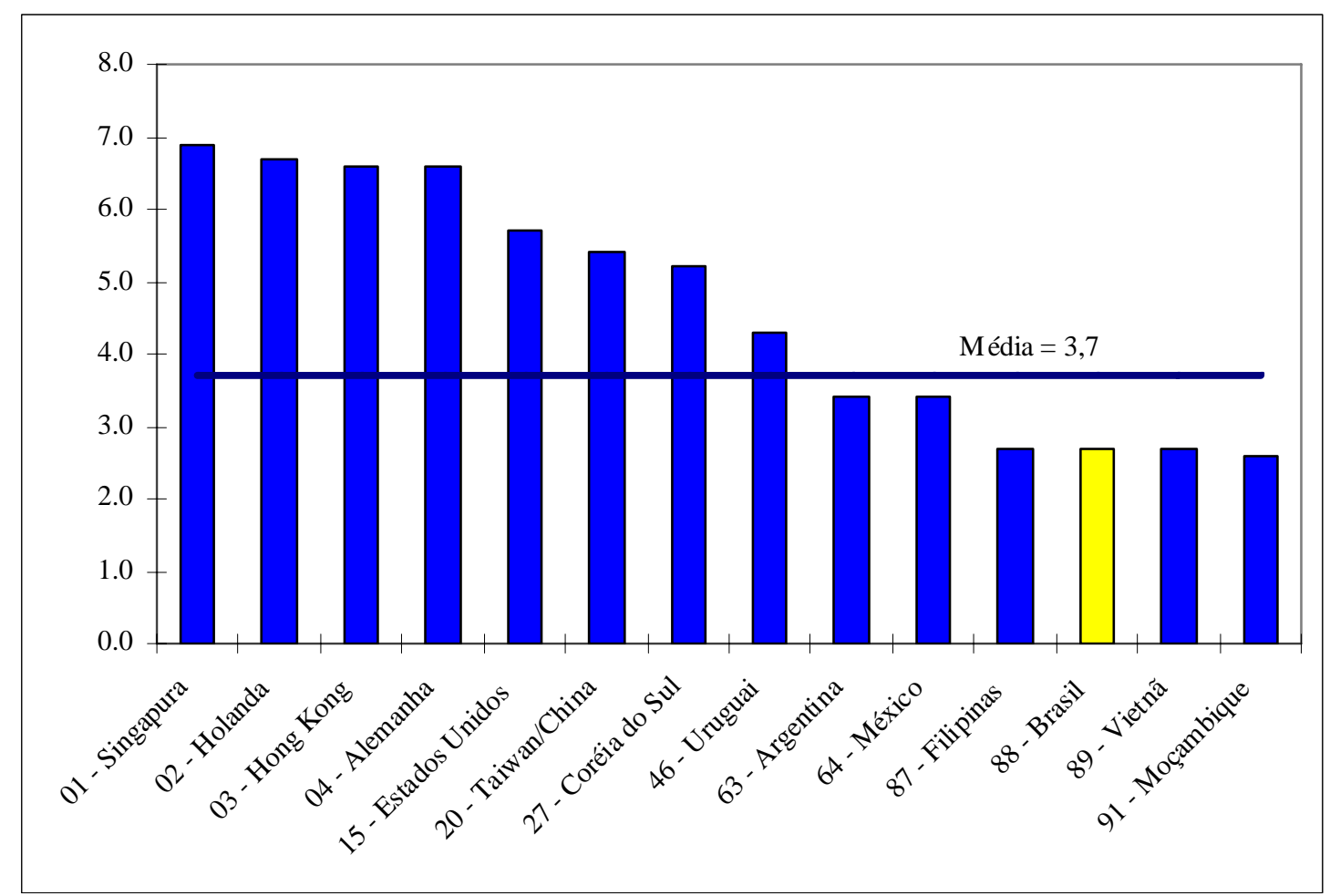

Fonte: GCR (2006)

Com o intuito de aumentar a eficiência dos portos e reduzir este componente do “custo Brasil”, mudanças têm sido feitas no marco regulatório do setor portuário brasileiro desde o início da década de noventa ${ }^{3}$. Um levantamento da história recente da regulação deste setor nos conduz ao ano de 1975, quando foi criada a Portobrás com o objetivo de construir, explorar e administrar os portos brasileiros. Em 1990, ano da extinção da Portobrás, alguns portos eram administrados diretamente por esta, outros por suas subsidiárias, as Companhias Docas, por concessões estaduais e privadas. Os problemas enfrentados pelo setor à época incluíam, entre outros, equipamentos obsoletos, déficit de investimentos, elevado tempo de espera para atracação e permanência das embarcações no porto e monopólios da escalação da mão-de-obra.

\footnotetext{
${ }^{3}$ O que se segue é baseado em BNDES (2001).
} 
Em fevereiro de 1993 foi promulgada a “Lei de Modernização dos Portos” (Lei 8.630/93) que visava promover a descentralização no setor, permitir a entrada de recursos privados, estimular investimentos, promover a concorrência e adequar o quantitativo da mão-de-obra aos novos padrões tecnológicos. Para tal foram criados: o Operador Portuário (OP), pessoa jurídica pré-qualificado para executar a ação portuária; a Autoridade Portuária (AP), responsável pela fiscalização da manutenção e gestão do patrimônio e conservação da eficiência portuária; Conselho da Autoridade Portuária (CAP), formado por representantes do poder público, da OP, dos trabalhadores e usuários; e o Órgão Gestor da Mão-de-Obra (OGMO).

Os portos são fundamentais ao Brasil dada a importância do transporte marítimo para o comércio internacional. Esta importância pode ser mensurada através dos dados nas Tabelas 1.1 e 1.2. Em 2002, 79,89\% das exportações brasileiras (em US\$) foram feitas por via marítima; em 2003 e 2004, este número foi 85,54\% e 80,94\%, respectivamente. As exportações brasileiras aumentaram 59,82\% entre 2002 e 2004; no mesmo período, o uso da via marítima para transporte das exportações cresceu 61,91\%.

Em relação às importações o quadro é similar. Em 2004, 68,18\% das importações brasileiras em US\$ e 88,94\% em kg utilizaram-se da via marítima. Em termos do valor importado (US\$) a via aérea foi o segundo meio mais importante com 24,89\%, mas devemos ressaltar que o custo de utilizar a via aérea é elevado e só justificado no caso de produtos com alto valor unitário, por isso sua participação nas importações em kg é baixa (0,19\%). 
Tabela 1.1 - Exportações por via de transporte (\%)

\begin{tabular}{lcccccc}
\hline & \multicolumn{3}{c}{ US\$ } & \multicolumn{4}{c}{ Kg Líquido } \\
Via de Transporte & $\mathbf{2 0 0 2}$ & $\mathbf{2 0 0 3}$ & $\mathbf{2 0 0 4}$ & $\mathbf{2 0 0 2}$ & $\mathbf{2 0 0 3}$ & $\mathbf{2 0 0 4}$ \\
\hline LINHA DE TRANSMISSÃO & 0.24 & 0.28 & 1.26 & 0.01 & 0.01 & 0.05 \\
MARÍTIMA & 79.89 & 82.54 & 80.94 & 96.09 & 95.49 & 93.27 \\
FLUVIAL & 1.07 & 0.63 & 0.69 & 2.15 & 2.59 & 4.83 \\
AÉREA & 7.82 & 6.49 & 5.57 & 0.14 & 0.06 & 0.06 \\
POSTAL & 0.00 & 0.00 & 0.00 & 0.00 & 0.00 & 0.00 \\
FERROVIÁRIA & 0.22 & 0.23 & 0.26 & 0.10 & 0.13 & 0.14 \\
RODOVIÁRIA & 5.44 & 6.15 & 6.70 & 1.09 & 1.23 & 1.20 \\
MEIOS PRÓPRIOS & 5.32 & 3.67 & 4.58 & 0.43 & 0.49 & 0.46 \\
\hline TOTAL & $\mathbf{1 0 0}$ & $\mathbf{1 0 0}$ & $\mathbf{1 0 0}$ & $\mathbf{1 0 0}$ & $\mathbf{1 0 0}$ & $\mathbf{1 0 0}$ \\
\hline
\end{tabular}

Fonte: MDIC, Aliceweb.

Tabela 1.2 - Importações por via de transporte (\%)

\begin{tabular}{lcccccc}
\hline & \multicolumn{3}{c}{ US\$ } & \multicolumn{4}{c}{ Kg Líquido } \\
Via de Transporte & $\mathbf{2 0 0 2}$ & $\mathbf{2 0 0 3}$ & $\mathbf{2 0 0 4}$ & $\mathbf{2 0 0 2}$ & $\mathbf{2 0 0 3}$ & $\mathbf{2 0 0 4}$ \\
\hline LINHA DE TRANSMISSÃO & 0.07 & 0.07 & 0.11 & 0.01 & 0.01 & 0.02 \\
MARÍTIMA & 69.01 & 68.82 & 68.18 & 89.30 & 88.42 & 88.94 \\
FLUVIAL & 0.00 & 0.00 & 0.00 & 0.02 & 0.03 & 0.03 \\
LACUSTRE & 0.00 & 0.00 & 0.01 & 0.01 & 0.01 & 0.02 \\
AÉREA & 23.83 & 23.72 & 24.89 & 0.16 & 0.15 & 0.19 \\
POSTAL & 0.01 & 0.01 & 0.01 & 0.00 & 0.00 & 0.00 \\
FERROVIÁRIA & 0.24 & 0.24 & 0.23 & 0.34 & 0.30 & 0.29 \\
RODOVIÁRIA & 5.69 & 5.99 & 5.46 & 5.41 & 6.32 & 4.68 \\
TUBO-CONDUTO & 0.78 & 0.89 & 0.93 & 4.75 & 4.75 & 5.83 \\
MEIOS PRÓPRIOS & 0.37 & 0.25 & 0.18 & 0.01 & 0.01 & 0.01 \\
\hline TOTAL & $\mathbf{1 0 0}$ & $\mathbf{1 0 0}$ & $\mathbf{1 0 0}$ & $\mathbf{1 0 0}$ & $\mathbf{1 0 0}$ & $\mathbf{1 0 0}$ \\
\hline
\end{tabular}

Fonte: MDIC, Aliceweb. 
As informações apresentadas dão uma idéia em certo sentido incompleta da importância dos portos para a economia brasileira. Para se auferir corretamente a importância dos portos para o Brasil, deveríamos ter uma estimativa de quanto do custo total de transportar uma mercadoria de um país estrangeiro para o Brasil, ou em sentido inverso, é relativo ao porto escolhido para integrar a cadeia de transporte. Outra informação importante, em particular para a agência responsável pela regulação do setor, a Agência Nacional de Transportes Aquaviários (Antaq), é a diferença de custos entre os portos.

Uma crescente - mas ainda pequena - literatura vem tentando diferentes abordagens para obter estimativas destas informações, em especial, sobre eficiência portuária. No entanto, não existem trabalhos focando o Brasil que cubram uma amostra extensa dos portos brasileiros.

O presente trabalho visa preencher estas lacunas da literatura. Selecionamos uma amostra contendo 13 dos portos mais importantes do Brasil - Rio Grande, Itajaí, São Francisco do Sul, Paranaguá, Santos, Vitória, Sepetiba, Rio de Janeiro, Salvador, Aratu, Suape, Fortaleza e Belém - que foram responsáveis por 67,3\% do peso e 54\% do valor importados em 2002. Através de dados das importações brasileiras do ano de 2002 que registraram como porto de entrada os portos selecionados, desenvolvemos um modelo econométrico [baseado em Blonigen \& Wilson (2006)] que permite medir a variação do custo de importar uma mercadoria devido aos portos. O modelo permite-nos ainda ter uma idéia da eficiência relativa entre os portos da amostra, ou seja, em condições semelhantes qual porto oferece o menor custo.

O restante do trabalho está organizado da seguinte forma. No capítulo 2, descrevemos com maior detalhe os portos que compõem a amostra e apresentamos algumas informações sobre 
sua importância para o comércio internacional brasileiro. O capítulo 3 é uma revisão bibliográfica de trabalhos que lidaram com a questão de eficiência portuária. No capítulo 4, são apresentados a metodologia adotada e os resultados obtidos. Algumas conclusões compõem o capítulo 5. 


\section{CAPÍTULO 2. Os portos no comércio internacional brasileiro}

Os dados na amostra são referentes a treze portos: Rio Grande, Itajaí, São Francisco do Sul, Paranaguá, Santos, Vitória, Sepetiba, Rio de Janeiro, Salvador, Aratu, Suape, Fortaleza e Belém que foram responsáveis por $67,3 \%$ do peso e $54 \%$ do valor importados em 2002. A localização destes portos pode ser visualizada na Figura 2.1. Neste capítulo apresentaremos os portos que compõem nossa amostra e sua escolha será justificada, ao menos em parte, pelas informações levantadas. A seção 2.1 contém informações sobre os portos tais como administração, volume de cargas movimentadas, tipo de carga movimentada, entre outras.

As seções seguintes, 2.2 e 2.3, apresentam uma investigação sobre a importância de cada Unidade da Federação (UF) para a movimentação de cargas observada nos portos estudados e a participação dos portos da amostra no comércio internacional das UFs, respectivamente. Em ambos os casos, fazemos uso de linhas de desejo, isto é, figuras representando o Brasil dividido em UFs contendo linhas representando fluxos de mercadorias, por exemplo, que partem de um estado específico para os portos da amostra representando o volume de mercadorias exportadas pelo estado em questão que passam pelos portos da amostra; a espessura da linha é proporcional ao volume do fluxo. Embora o uso de linhas de desejo seja comum na engenharia de transporte, este instrumento é pouco conhecido na economia. Por exemplo, temos conhecimento de apenas um estudo que procura estruturar uma metodologia de análise econômica dos portos brasileiros ${ }^{4}$; este estudo, contudo, não faz uso de linhas de desejo. Este capítulo visa ainda trazer para a análise econômica dos portos este instrumental. Por fim, a seção 2.4 é uma síntese das informações levantadas nas seções anteriores.

\footnotetext{
${ }^{4}$ Campos Neto (2006).
} 


\section{Figura 2.1. Localização dos Portos}

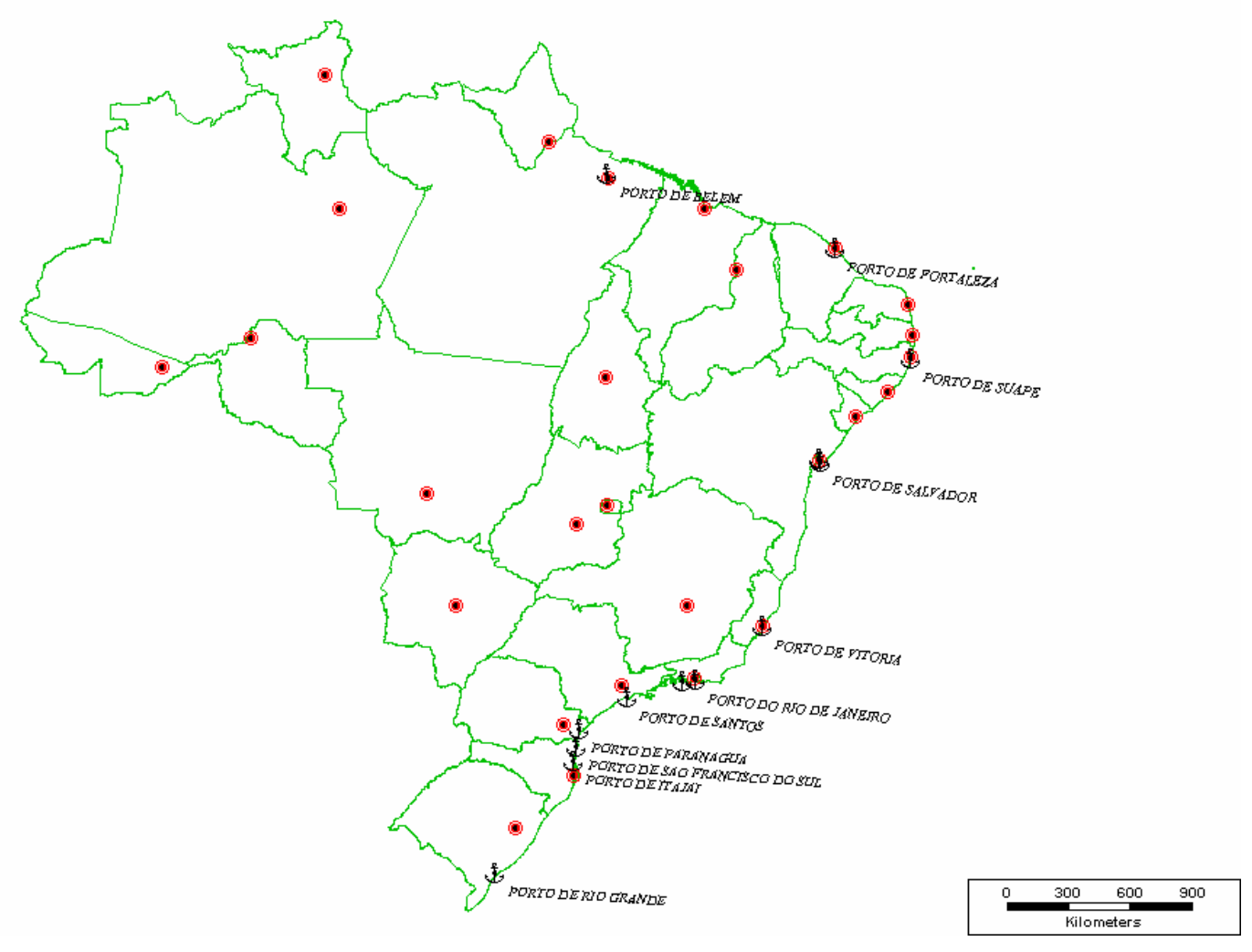

\subsection{Portos: Informações gerais}

Segundo o Anuário Estatístico Portuário de 2004, da Agência Nacional de Transportes Aquaviários (ANTAQ), dos portos pertencentes a nossa amostra, apenas o porto de São Francisco do Sul permanecia no regime de concessão ao Governo do Estado de Santa Catarina, sendo administrado pela autarquia estadual Administração do Porto de São Francisco do Sul. Os portos de Paranaguá, Rio Grande e Itajaí estavam sob o regime de delegação, os dois primeiros aos governos dos estados em que se localizam - Paraná e Rio Grande do Sul, respectivamente - e o último à Prefeitura Municipal de Itajaí. Estavam sob o controle do governo federal e eram administrados por empresas ligadas ao Ministério dos Transportes os portos de Belém, Fortaleza, Salvador, Aratu, Vitória, Rio de Janeiro, Sepetiba 
e Santos. O porto de Suape encontrava-se sob regime de autorização e era administrado pela empresa homônima.

A Tabela 2.1. permite comparar a escala dos portos estudados de acordo com a movimentação de carga. Considerando o total de carga movimentada, podemos separar os portos em quatro grupos. No primeiro, estão Santos e Sepetiba, os maiores portos da amostra. No segundo, estão portos com de 30 a 40\% da carga movimentada de Santos, são eles: Belém, Aratu, Paranaguá e Rio Grande. O terceiro grupo é composto por Rio de Janeiro e São Francisco do Sul, portos com entre 20 e 25\% da carga movimentada de Santos. No quarto grupo estão os demais portos que movimentaram ao redor de $10 \%$ ou menos da carga movimentada pelo porto de Santos.

Tabela 2.1 - Movimentação de Cargas, por natureza, 2004 (em toneladas)

\begin{tabular}{lcccc}
\hline & \multicolumn{4}{c}{ 2004 } \\
\cline { 2 - 5 } \multicolumn{1}{c}{ Porto } & Granel & Granel & Carga & \\
\hline Belém & Sólido & Líquido & Geral & Total \\
Fortaleza & 16.960 .556 & 1.728 .503 & 1.370 .798 & 20.059 .857 \\
Suape & 840.375 & 1.495 .156 & 1.756 .842 & 4.092 .373 \\
Salvador & 0 & 2.273 .041 & 1.643 .946 & 3.916 .987 \\
Aratu & 697.146 & 0 & 2.255 .947 & 2.953 .093 \\
Vitória & 3.244 .946 & 23.194 .943 & 0 & 26.439 .889 \\
Rio de Janeiro & 3.201 .130 & 200.726 & 3.946 .056 & 7.347 .912 \\
Sepetiba & 828.897 & 8.080 .432 & 5.626 .336 & 14.535 .665 \\
Santos & 56.803 .864 & 0 & 2.482 .185 & 59.286 .049 \\
Paranaguá & 27.898 .592 & 13.508 .837 & 26.202 .324 & 67.609 .753 \\
São Francisco do Sul & 21.085 .082 & 3.783 .474 & 6.612 .633 & 31.481 .189 \\
Itajaí & 3.048 .945 & 9.400 .787 & 3.584 .931 & 16.034 .663 \\
Rio Grande & 0 & 67.824 & 5.371 .500 & 5.439 .324 \\
\hline Fonte: Antáno Estísico Pont & 12.291 .273 & 3.918 .099 & 6.038 .162 & 22.247 .534 \\
\hline
\end{tabular}

Fonte: Anuário Estatístico Portuário, 2004, Antaq.

As cargas transportadas pelo modal marítimo são divididas em três segmentos: granéis sólidos, granéis líquidos e carga geral. Cargas do tipo granel sólido são compostas por 
mercadorias como minério de ferro, carvão, grãos, bauxita, açúcar, sal, etc. Granéis líquidos são compostos por mercadorias como petróleo, produtos petrolíferos e gases líquidos. No segmento de carga geral são incluídos produtos diversos que se distinguem ainda pela forma de manipulação e transporte; estão neste grupo mercadorias como produtos agrículos em sacarias, frutas e carnes transportadas em porões frigoríficos e carros e carretas, entre outros. As cargas gerais dividem-se ainda em dois tipos, solta ou conteinerizada.

Os portos de Belém, Sepetiba, Paranaguá e Rio Grande lidam principalmente com cargas do tipo granel sólido (Tabela 2.2.). Notamos no caso de Sepetiba uma queda ligeira nos últimos anos da movimentação de cargas deste tipo em favor de carga geral, mas a movimentação deste tipo de carga por aquele porto ainda permanece muito reduzida. Em 2004, o porto de Sepetiba foi o terceiro maior em movimentação de granéis sólidos no Brasil, ficando atrás apenas de Tubarão (ES) e Itaqui (MA). Sepetiba respondeu por 15,4\% da movimentação total deste tipo de carga em todos os portos brasileiros no ano de 2004, de acordo com o Anuário Estatístico Portuário deste ano.

Já os portos de Suape, Aratu, Rio de Janeiro e São Francisco do Sul movimentaram principalmente cargas do tipo granel líquido; com exceção de Aratu, os outros portos mostraram em anos recentes tendência de reduzir a movimentação de granéis líquidos em favor de carga do tipo carga geral. O porto de Aratu foi aquele que movimentou mais granéis líquidos no Brasil em 2004, alcançando uma participação de 14\% na movimentação nacional de granéis líquidos por portos brasileiros.

O porto de Fortaleza mostrava em 2000 uma forte concentração na movimentação de granéis sólidos. Porém, em 2004, o porto movimentava principalmente cargas gerais e líquidas, 
apesar de ainda contar com uma alta participação de granéis sólidos entre as cargas movimentadas. Salvador e Itajaí lidam principalmente com carga geral e têm se especializado mais neste tipo de carga no período 2000-2004. Os portos de Santos e Vitória têm em granéis sólidos e carga geral seus mais importantes tipos de carga movimentados. Entre 2000-2004 também apresentaram uma tendência de aumento da movimentação de carga geral (Tabela 2.2.). O porto de Santos foi aquele que mais movimentou carga do tipo geral em 2004 entre os portos brasileiros; Santos respondeu por cerca de 30\% da carga geral movimentada por portos brasileiros em 2004.

Tabela 2.2 - Tipos de carga movimentada por porto, 2000 e 2004 (\%)

\begin{tabular}{lcccccc}
\hline & \multicolumn{9}{c}{$\mathbf{2 0 0 0}$} & & & $\mathbf{2 0 0 4}$ & \\
\cline { 2 - 7 } \multicolumn{1}{c}{ Porto } & Granel & Granel & Carga & Granel & Granel & Carga \\
Lólido & Líquido & Geral & Sólido & Lerdo & Geral \\
\hline Belém & 81,55 & 9,62 & 8,82 & 84,55 & 8,62 & 6,83 \\
Fortaleza & 83,45 & 10,92 & 5,63 & 20,54 & 36,54 & 42,93 \\
Suape & 0,00 & 83,41 & 16,59 & 0,00 & 58,03 & 41,97 \\
Salvador & 24,88 & 0,50 & 74,62 & 23,61 & 0,00 & 76,39 \\
Aratu & 13,44 & 86,56 & 0,00 & 12,27 & 87,73 & 0,00 \\
Vitória & 58,47 & 2,66 & 38,87 & 43,57 & 2,73 & 53,70 \\
Rio de Janeiro & 4,80 & 65,56 & 29,63 & 5,70 & 55,59 & 38,71 \\
Sepetiba & 98,70 & 0,00 & 1,30 & 95,81 & 0,00 & 4,19 \\
Santos & 44,57 & 24,75 & 30,68 & 41,26 & 19,98 & 38,76 \\
Paranaguá & 66,01 & 17,15 & 16,84 & 66,98 & 12,02 & 21,01 \\
São Francisco do Sul & 16,54 & 69,82 & 13,63 & 19,01 & 58,63 & 22,36 \\
Itajaí & 5,37 & 3,24 & 91,38 & 0,00 & 1,25 & 98,75 \\
Rio Grande & 50,32 & 26,94 & 22,74 & 55,25 & 17,61 & 27,14 \\
\hline
\end{tabular}

Fonte: Anuário Estatístico Portuário, 2004, Antaq.

A conteinerização é uma tendência do transporte marítimo. De acordo com a ISO (International Standards Organization), um contêiner “é um cofre de carga móvel, ou seja, provido de dispositivos que permitem a sua manipulação; desenhado para o transporte multimodal; apto para o uso reiterado; dotado de marcas e sinais de identificação; com volume interno mínimo de $1 \mathrm{~m}^{3 \%}$ [Vieira (2003), pp. 63]. Entre os fatores que explicam o 
crescimento do uso de contêineres estão: sua adequação ao transporte intermodal; a preferência dos embarcadores e receptores ${ }^{5}$ devido à redução do custo de carga e descarga e da manipulação da carga o que evita avarias e roubos, possibilitando redução do seguro; e as vantagens aos armadores ${ }^{6}$ na forma de economias de escala através da redução do tempo de estadia nos portos e diminuição dos gastos de estiva [Vieira (2003), pp. 64].

\footnotetext{
${ }^{5}$ Embarcador é aquele que entrega a mercadoria para embarque, não necessariamente o exportador. Receptor é aquele que recebe a mercadoria desembarcada.

${ }^{6}$ Armador: indivíduo ou empresa proprietário de navio e que tem trabalhadores ao seu serviço.
} 
Tabela 2.3 - Participação dos portos na

movimentação total de contêineres no Brasil, 2000-2004

\begin{tabular}{lccccc}
\hline \multirow{1}{*}{\multicolumn{1}{c}{ Porto }} & \multicolumn{5}{c}{ TEU $^{*}$} \\
\cline { 2 - 6 } & $\mathbf{2 0 0 0}$ & $\mathbf{2 0 0 1}$ & $\mathbf{2 0 0 2}$ & $\mathbf{2 0 0 3}$ & $\mathbf{2 0 0 4}$ \\
\hline Belém & 1,99 & 1,66 & 1,50 & 1,11 & 1,11 \\
Fortaleza & 2,80 & 1,48 & 2,08 & 1,84 & 1,64 \\
Suape & 2,54 & 2,59 & 3,12 & 1,46 & 2,68 \\
Salvador & 3,86 & 3,65 & 3,86 & 4,05 & 3,84 \\
Aratu & $\mathrm{ND}$ & $\mathrm{ND}$ & $\mathrm{ND}$ & $\mathrm{ND}$ & $\mathrm{ND}$ \\
Vitória & 3,71 & 3,19 & 3,68 & 3,44 & 3,81 \\
Rio de Janeiro & 8,80 & 8,62 & 7,78 & 7,80 & 6,89 \\
Sepetiba & 0,15 & 0,58 & 0,57 & 0,65 & 2,64 \\
Santos & 32,43 & 30,52 & 30,60 & 33,22 & 35,00 \\
Paranaguá & 10,24 & 9,64 & 7,73 & 7,43 & 7,58 \\
São Francisco do Sul & 6,82 & 6,03 & 7,41 & 6,74 & 6,11 \\
Itajaí & 7,16 & 8,33 & 9,58 & 10,60 & 11,28 \\
Rio Grande & 12,83 & 11,84 & 12,55 & 12,54 & 11,45 \\
\hline
\end{tabular}

Fonte: Anuário Estatístico Portuário, 2004, Antaq.

${ }^{*}$ TEU - unidade equivalente a 20-pés. Unidade que transforma contêineres de diversos tamanhos no tipo padrão de 20-pés.

O porto de Santos foi responsável por mais de um terço da movimentação de contêineres no Brasil em 2004 (Tabela 2.3.). Outros portos da amostra estudada que, no período 2000-2004, se destacam pela movimentação de contêineres foram Itajaí e Rio Grande. No outro extremo, os portos de Belém e Fortaleza foram aqueles que tiveram a menor participação na movimentação nacional de contêineres entre os portos da amostra, em 2004.

Devemos notar que parte das diferenças no uso de contêineres entre os portos da amostra é devida às diferenças nos tipos de carga movimentadas, isto porque o uso de contêineres é associado na, maior parte das vezes, ao transporte de carga geral. No caso dos portos pertencentes a nossa amostra, também encontramos este resultado como pode ser visto no Gráfico 2.1., no qual excluímos apenas por conveniência os portos de Aratu e Santos, que, embora confirmem esta relação, dificultavam sua visualização no gráfico. 


\section{Gráfico 2.1. Relação entre o número de contêineres e carga geral movimentados}

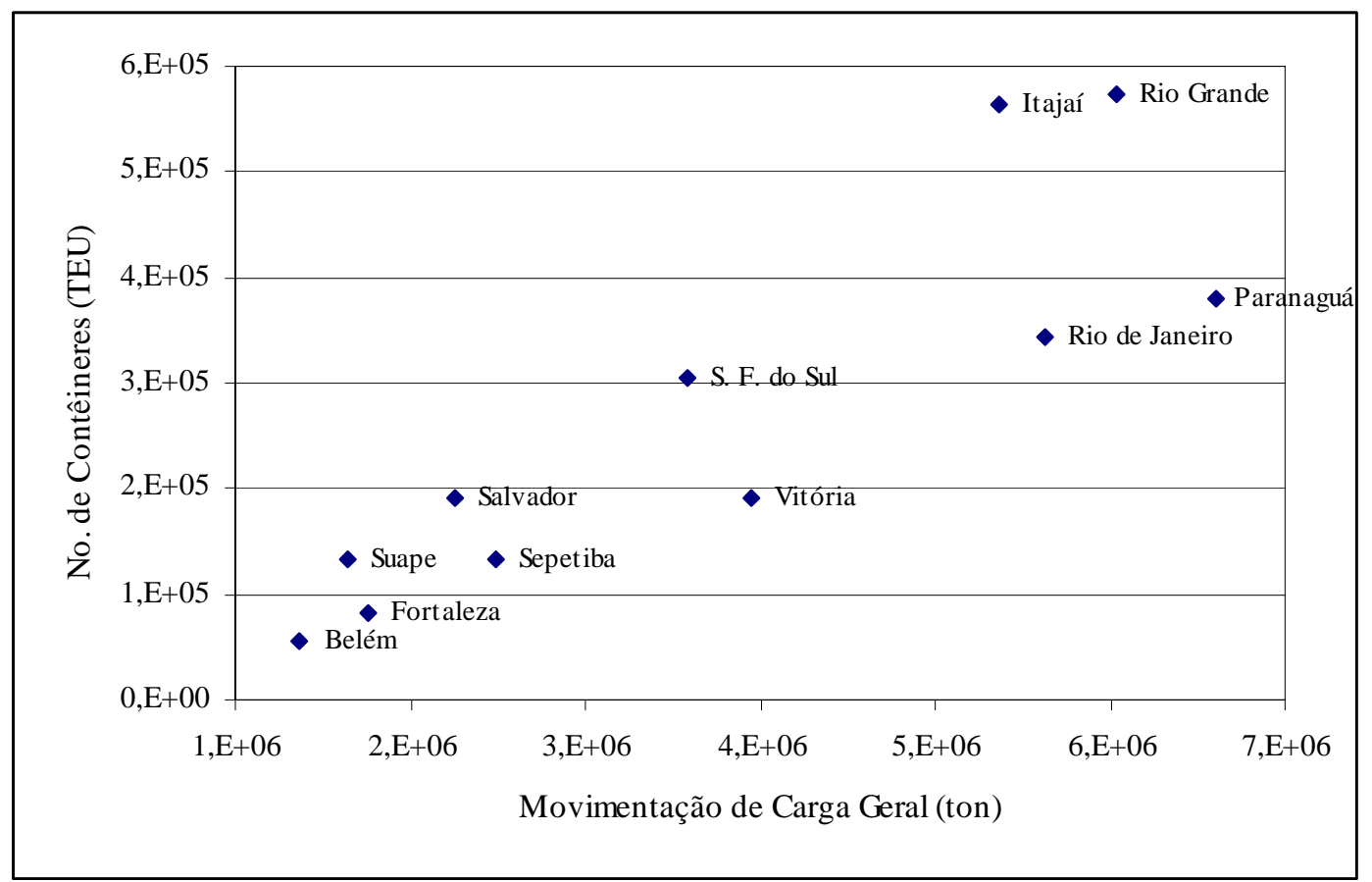

Fonte: Anuário Estatístico Portuário, 2004, Antaq.

Logo, uma parcela da movimentação de contêineres pelo porto de Santos deve ser atribuída ao fato apontado anteriormente deste ser o principal porto brasileiro em movimentação de carga geral. Da mesma maneira, a baixa movimentação de contêineres por portos como Belém e Sepetiba é em parte função destes portos movimentarem principalmente granéis sólidos.

\subsection{Importância do comércio internacional das UFs brasileiras para os portos}

Nesta seção iremos avaliar quais os estados de destino das importações que passam pelos portos que compõem nossa amostra e quais são as UFs de origem das mercadorias exportadas através dos portos da amostra. Em outras palavras, analisaremos do ponto de vista deste grupo de portos quais são as UFs cujo comércio internacional é mais importante. 
Faremos isto através do uso de linhas de desejo: linhas representando o fluxo de mercadorias (US\$ FOB) que entram por um determinado porto e destinam-se aos estados ou partem dos estados e destinam-se aos portos para daí serem exportadas; cada linha é proporcional ao fluxo que representa. Os dados foram obtidos no MDIC, Aliceweb, e são referentes ano de 2002, pois este é o ano que serviu de base para as estimações no capítulo 4. Devido à restrição dos dados supomos que o comércio internacional dos estados é realizado totalmente a partir de suas capitais. Para permitir uma visualização mais clara eliminamos fluxos que sejam muito pequenos (menos de 0,1\%). As figuras contendo as linhas de desejo encontram-se no Apêndice A.1. Em alguns casos, devido à proximidade entre o porto e a capital do estado não é possível visualizar a linha de desejo; por isso, inserimos no Apêndice A.1 uma tabela com as participações dos estados no total das mercadorias que passam pelos portos.

Os destinos mais importantes das mercadorias que entram no Brasil pelo porto de Belém são Pará, Maranhão, Goiás e São Paulo. O porto é de fundamental importância para as importações paraenses. O porto de Belém também é a via de entrada de um quarto dos reatores nucleares, caldeiras e máquinas e aparelhos mecânicos, um terço dos combustíveis minerais e $70 \%$ do material elétrico importados pelo Pará. Destacamos ainda que mais de 80\% dos produtos do material elétrico importados pelo Maranhão entram no Brasil pelo porto de Belém.

O Pará é o principal exportador pelo porto de Belém, seguido por São Paulo e Maranhão. Madeiras, carvão vegetal e obras de madeira são os principais produtos exportados pelo Pará e Maranhão através de Belém, sendo que mais de 90\% das exportações destas mercadorias por aquelas UFs utiliza este porto como via de saída. 
Os principais destinos no Brasil das mercadorias que entram pelo porto de Fortaleza são o próprio Ceará, Maranhão e Rio Grande do Norte. O porto de Fortaleza é o via de entrada mais importante dos produtos mais relevantes na pauta de importações do Ceará. Acima de 80\% dos produtos de material elétrico; a quase totalidade dos cereais, combustíveis minerais e ferro fundido, ferro e aço; e três quartos reatores nucleares, caldeiras e máquinas importados pelo Ceará entram por este porto.

Rio Grande do Sul, Bahia, Pernambuco, Paraíba, Rio Grande do Norte, Ceará e Piauí exportam mercadorias através do porto de Fortaleza. As UFs do Nordeste exportam por este porto produtos têxteis, artigos de couro, frutas e peixes e crustáceos. O porto de Fortaleza parece ser mais importante para as exportações do Ceará, Rio Grande do Norte e Piauí na medida em que os produtos mais importantes nas pautas de exportações destes utilizam-no como via de escoamento de seus produtos.

O porto de Suape abastece principalmente Pernambuco, Sergipe, Paraíba, Rio Grande do Norte e Ceará. Um quarto das importações de Pernambuco correspondem a combustíveis minerais dos quais 95\% são importados através do porto de Suape. O porto é ainda uma importante via de entrada de importações de alumínio e suas obras das UFs citadas.

As exportações brasileiras que saem do porto de Suape partem de Pernambuco, Paraíba, Rio Grande do Norte, Ceará, Alagoas e São Paulo, entre outros. O porto é importante, em particular, para a economia de Pernambuco, Paraíba e Rio Grande do Norte, já que, é responsável por grande parte das exportações dos principais produtos que compõem a pauta de exportações destas UFs, como calçados, frutas e peixes e crustáceos. 
Os destinos mais importantes dos produtos que chegam ao porto de Salvador vindos do exterior são Bahia e Sergipe. No caso da Bahia, destacam-se as importações de veículos automóveis e máquinas e aparelhos mecânicos por este porto. Em relação ao Sergipe, o porto de Salvador é a via de entrada de dois terços das importações de máquinas e aparelhos mecânicos.

Pelo porto de Salvador são exportados produtos vindos da Bahia, Sergipe, São Paulo Minas Gerais e Alagoas, entre outros. O porto é importante como via de saída das exportações da Bahia (cobre e suas obras, cacau e suas preparações e produtos químicos orgânicos), Sergipe (produtos de perfumaria, peles e couros) e Alagoas (fumo e seus sucedâneos manufaturados).

O principal destino das mercadorias que chegam ao porto de Aratu vindas do resto do mundo é a Bahia. Entre as mercadorias importadas pela Bahia através deste porto destacamos naftas para petroquímica e sulfetos de minério de cobre. De fato, este é um porto importante como via de entrada das importações baianas: quase a totalidade das mercadorias combustíveis minerais e minérios (entre as cinco mais importadas pela UF) entram através deste porto.

O porto de Aratu é utilizado quase exclusivamente como canal de saída das exportações da Bahia e as principais mercadorias que a UF exporta por ele são combustíveis minerais e produtos químicos orgânicos. Estas duas mercadorias são as mais exportadas pela Bahia e metade da primeira e mais de $90 \%$ da segunda saem pelo porto de Aratu.

Os principais destinos no Brasil das mercadorias que chegam ao porto de Vitória são Espírito Santo e Minas Gerais. A pauta de importações destes depende fundamentalmente deste porto na medida em que ele é a principal, quando não a única, via de entrada de mercadorias 
destinadas a estas UFs. Alagoas, assim como Sergipe e Rio Grande do Norte, tem em materiais elétricos seu principal produto de importação e o porto de Vitória é a via de entrada da grande maioria destes produtos.

As mercadorias exportadas pelo porto de Vitória partem principalmente do Espírito Santo, Minas Gerais, Bahia, Goiás e Mato Grosso do Sul. De fato, o porto de Vitória é praticamente a única via de saída das exportações do Espírito Santo. A maioria dos minérios, ferro fundido, ferro e aço, além da quase totalidade de pasta química de madeira, exportada por Minas Gerais (produtos cuja participação somada na pauta de exportações mineira ultrapassa 50\%) têm no porto de Vitória sua via de escoamento.

Os produtos que entram no porto do Rio de Janeiro vindos do exterior destinam-se principalmente à região Sudeste, em especial, para o Rio de Janeiro e Minas Gerais. Este porto mostra-se mais relevante para as importações de máquinas e aparelhos mecânicos e produtos químicos orgânicos do Rio de Janeiro e para as importações de máquinas e aparelhos mecânicos e veículos automóveis de Minas Gerias. No caso de ambas UFs, as mercadorias destacadas representam produtos de destaque em suas pautas de importação.

As exportações brasileiras que partem do porto de Rio de Janeiro provem do Rio de Janeiro e de São Paulo. Dos produtos que se destacam na pauta de exportações fluminenses aqueles que mais utilizam o porto de Rio de Janeiro são máquinas e aparelhos mecânicos e produtos químicos orgânicos. Vale mencionar ainda que quase 10\% das exportações da UF de combustíveis minerais passam por este porto, já que, mais da metade da pauta de exportações fluminense é tomada por estes produtos. 
Os principais destinos das mercadorias importadas através do porto de Sepetiba são Rio de Janeiro e Minas Gerais. No caso do Rio de Janeiro, o comércio dos dois produtos mais importados por este dependem crucialmente de Sepetiba. Há um fluxo de Sepetiba para Rondônia, resultado das importações deste de cereais que chegam ao Brasil exclusivamente por aquele porto.

O Rio de Janeiro é o principal exportador através do porto de Sepetiba, e este é fundamental para as exportações fluminenses. Metade das exportações do Rio de Janeiro corresponde a combustíveis minerais, dos quais mais de $40 \%$ passam por Sepetiba. Do segundo produto mais exportado pela UF (ferro fundido,ferro e aço) mais de $60 \%$ são exportados através de Sepetiba.

As mercadorias que entram no porto de Santos vindas do exterior destinam-se a São Paulo, Minas Gerais, Paraná, Rio Grande do Sul, Rio de Janeiro e Goiás, entre outros. O porto de Santos é a principal via de entrada de algumas das mercadorias mais importantes na pauta de importações de São Paulo, por exemplo, metade das máquinas e aparelhos mecânicos importados pela UF (produto que responde por um quinto das importações paulistas) entra através do porto de Santos. O mesmo ocorre com Minas Gerais, especialmente, em relação às importações de adubos e fertilizantes.

As exportações de São Paulo, Mato Grosso do Sul e Minas Gerais através do porto de Santos se destacam. Os produtos mais exportados por estes dependem maciçamente do porto de Santos como via de saída. Por exemplo, o produto mais importante na pauta de exportações paulista são veículos automóveis, dos quais mais de 80\% são exportados através de Santos. Carnes e miudezas respondem por um terço das exportações do Mato Grosso do Sul e o porto 
de Santos é a via de saída de quase 30\% destas mercadorias. Santos é o porto de saída da maior parte das exportações mineiras de café.

Paraná, São Paulo, Mato Grosso do Sul e Goiás são os destinos mais relevantes das mercadorias que entram por Paranaguá. Este porto é bastante importante para as importações do Paraná, Goiás e Mato Grosso do Sul, pois os principais produtos na pauta de importações destes utilizam-no como via de entrada extensivamente. Por exemplo, um quinto das importações do Paraná correspondem a máquinas e aparelhos mecânicos, dos quais 70\% passam por Paranaguá. No caso de Goiás, 16\% de suas importações corresponderam a adubos ou fertilizantes, dos quais $80 \%$ entram pelo porto.

As principais UFs que usam o porto de Paranaguá para escoarem suas exportações são Paraná, São Paulo, Mato Grosso do Sul e Santa Catarina. As exportações do Paraná e Mato Grosso do Sul são bastante dependentes deste porto. Os dois produtos mais exportados pelo Paraná são veículos automóveis e sementes e frutos oleaginosos e em ambos os casos, mais de $80 \%$ das exportações ocorrem através de Paranaguá. Metade das exportações do Mato Grosso do Sul da mercadoria resíduos e desperdícios das indústrias alimentares (segundo produto na pauta de exportações desta UF) ocorre por este porto.

Paraná, Santa Catarina e São Paulo são os principais destinos das mercadorias que chegam ao porto de São Francisco do Sul. O terceiro produto mais importado pelo Paraná é combustíveis minerais, dos quais aproximadamente $90 \%$ passam por este porto. Santa Catarina é a UF que mais depende do porto de São Francisco do Sul para a importação dos principais produtos em sua pauta. O fluxo de exportações mais importante que passa por São Francisco do Sul 
origina-se em Santa Catarina. A UF depende deste porto, em especial, para suas exportações de produtos têxteis e móveis.

O principal destino das mercadorias que chegam ao porto de Itajaí é Santa Catarina, seguida de Paraná e São Paulo. Nas importações de Santa Catarina pelo porto de Itajaí destacam-se máquinas e aparelhos mecânicos, plásticos, materiais elétricos e cereais (trigo). Estes são os principais produtos da pauta de importações da UF e o porto de Itajaí mostra-se extremamente relevante para este comércio.

A região Sul é a principal usuária do porto de Itajaí para exportar produtos, em especial, Santa Catarina, além de São Paulo e Mato Grosso (mercadoria carne e miudezas). O porto tem grande importância para o comércio internacional de Santa Catarina dado que os cinco produtos mais importantes em sua pauta utilizam-no como principal via de saída.

Os principais destinos das mercadorias que chegam ao porto de Rio Grande são Rio Grande do Sul, Mato Grosso do Sul, Goiás, Paraná, Santa Catarina, Espírito Santo e São Paulo. Rio Grande do Sul, Mato Grosso do Sul, Paraná e Santa Catarina importam através deste porto adubos ou fertilizantes. Outros produtos de destaque da pauta de importações do Rio Grande do Sul também dependem do porto de Rio Grande como via de entrada. Santa Catarina também o usa para importar trigo e máquinas e aparelhos mecânicos, especialmente para trabalhar madeira.

A maior parte das exportações brasileiras que passa pelo porto de Rio Grande parte do Rio Grande do Sul, embora UFs mais distantes como São Paulo e Paraná também o utilizem. Os produtos mais importantes na pauta de exportação gaúcha dependem do porto de Rio Grande. 
O Paraná exporta principalmente por este porto couros e peles de bovinos e grãos de soja. As exportações paulistas que utilizam este porto consistem principalmente de peças e acessórios de veículos automóveis e calçados de couro.

\subsection{Importância dos portos para o comércio internacional das UFs brasileiras}

Nesta seção veremos, do ponto de vista das UFs, quais são os portos mais relevantes aos seus comércios internacionais. Mais uma vez, empregaremos linhas de desejo para fazê-lo. O Apêndice A.2 contém as figuras com as linhas de desejo e tabelas com a participação de cada porto da amostra no total importado e exportado por cada uma das UFs.

Destacamos a elevada participação, acima de dois terços, do porto de Paranaguá nas exportações de Rondônia; as principais mercadorias exportadas por esta UF através daquele porto foram: madeira, carvão vegetal e obras de madeira (que compõem mais de $80 \%$ da pauta de exportações do estado) e obras de pedra, gesso, cimento, amianto, etc.

O Acre dependeu, em 2002, fundamentalmente do porto de Paranaguá para importar mercadorias e para exportá-las, além do mesmo, do porto de Itajaí. O principal tipo de mercadoria importada pela UF em 2002 foram materiais elétricos e exportada, madeira, carvão vegetal e obras de madeira. Acima de 80\% das importações e exportações, em 2002, corresponderam as estas mercadorias e em ambos os casos os portos mencionados tiveram participação elevadas em seu transporte. 
Mais da metade das importações do Pará em 2002 utilizou o porto de Belém como via de entrada. Entretanto, as exportações da UF registraram naquele ano um baixo uso de Belém (menos de um quinto das mercadorias foi exportada através deste porto).

Destacamos a importância do porto de Santos para as importações de Tocantins. Dos cinco principais produtos na pauta de importações desta UF, quatro entram quase exclusivamente por Santos: alumínio e suas obras; obras de ferro fundido, ferro e aço; plástico e suas obras; e ferro fundido, ferro e aço.

O comércio internacional do Piaú mostrou-se muito ligado ao porto de Fortaleza, mais de 40\% das importações e 70\% das exportações do estado realizaram-se através de Fortaleza. Dos cinco principais produtos na pauta de exportações desta UF, quatro saíram quase exclusivamente por este porto: gorduras, óleos e ceras animais ou vegetais, vestuário e acessórios, frutas e peixes e crustáceos. O porto de Salvador também teve elevada participação na importação da UF em 2002.

O porto de Fortaleza mostrou-se extremamente importante para o comércio exterior do Ceará; tanto as principais mercadorias importadas por esta UF - material elétrico, cereais, combustíveis minerais, máquinas e equipamentos mecânicos, ferro fundido, ferro e aço quanto as principais exportadas - calçados, peixes e crustáceos, frutas, algodão, peles e couros - passaram por este porto.

Os portos de Fortaleza e Suape responderam em 2002 por, somados, mais da metade das exportações do Rio Grande do Norte. As importações desta UF realizaram-se principalmente por Vitória, Suape e Santos. 
Entre os portos que compõem a amostra, Suape foi o mais importante para o comércio internacional da Paraíba: quase um quinto das importações e mais de um terço das exportações utilizaram-no. Fortaleza também foi importante para as exportações desta UF.

Quase 70\% das mercadorias importadas por Pernambuco entraram pelo porto de Suape; em especial as importações de alumínio e suas obras, combustíveis minerais e material elétrico dependeram deste porto. A importância de Suape para as exportações pernambucanas foi menor, em torno de um terço, mesmo assim observamos que alguns dos principais bens exportados por esta UF, como produtos da indústria têxtil, calçados e peixes e crustáceos, foram exportadas amplamente através de Suape.

Alagoas dependeu em boa parte do porto de Vitória para suas importações. Em 2002, cerca de metade das importações desta UF corresponderam à mercadoria material elétrico, dos quais aproximadamente 90\% passaram pelo porto Vitória.

Entre os portos da amostra, Vitória, Salvador e, em menor escala, Suape tiveram uma participação relevante nas importações de Sergipe. Este resultado deveu-se, no caso de Vitória, ao uso deste como via de entrada de material elétrico, mercadoria mais importante na pauta de importações sergipana. Salvador foi utilizado pelo estado principalmente como via de entrada de máquinas e equipamentos mecânicos, enquanto que Suape foi a via de entrada da quase totalidade do alumínio e suas obras importados pelo estado. Nas exportações, somente o porto de Salvador teve uma participação de destaque, devido a sua importância nas exportações sergipanas de produtos de perfumaria, peles e couros. 
Os portos de Aratu e Salvador receberam mais de 85\% das importações e exportações baianas. Salvador foi importante particularmente para as importações da UF de veículos automóveis, tratores e suas partes, e máquinas e equipamentos mecânicos; Aratu recebeu a quase totalidade das importações de combustíveis minerais e minérios da Bahia. Estes portos foram importantes ainda para as exportações de produtos químicos orgânicos, combustíveis minerais, cobre e suas obras, e cacau e suas preparações bahianas.

As mercadorias importadas por Minas Gerais passaram principalmente pelos portos de Vitória, Rio de Janeiro e Santos. Já as exportações desta UF utilizaram principalmente o porto de Vitória, embora Rio de Janeiro e Santos também tivessem sido via de saída de um parte considerável das exportações mineiras.

O comércio internacional capixaba dependeu fundamentalmente do porto de Vitória em 2002. As principais mercadorias na pauta de importação do estado - máquinas e equipamentos mecânicos, veículos automóveis, tratores e suas partes, material elétrico, combustíveis minerais e filamentos sintéticos ou artificiais - e as principais mercadorias em sua pauta de exportação - ferro fundido, ferro e aço, minérios, pasta de madeira, café e obras de pedra foram comercializadas em larga escala através deste porto.

Dois terços das importações e exportações do Rio de Janeiro passaram pelos portos de Sepetiba e Rio de Janeiro. As principais importações fluminenses que entraram por Sepetiba foram combustíveis minerais e material elétrico; e, pelo porto de Rio de Janeiro, máquinas e equipamentos mecânicos e produtos químicos orgânicos. No lado das exportações, Sepetiba foi a principal via de saída de combustíveis minerais e ferro fundido, ferro e aço do estado; 
enquanto que Rio de Janeiro foi utilizado especialmente para as exportações fluminenses de produtos químicos orgânicos e máquinas e equipamentos mecânicos.

Entre os portos considerados, Santos foi o mais importante para o comércio internacional paulista, com participação superior a 50\% das importações desta UF e participação, nas exportações, superior a 60\%. Das importações da UF, aquelas que mais utilizaram Santos foram: plástico e suas obras e máquinas e equipamentos mecânicos. As exportações paulistas de veículos automóveis, tratores e suas partes, açúcares e produtos de confeitaria e máquinas e equipamentos mecânicos foram aquelas que mais dependeram de Santos.

O principal porto utilizado no comércio internacional do Paraná foi Paranaguá. Os principais produtos importados por esta UF em 2002 entraram maciçamente através deste porto, a exceção da mercadoria combustíveis minerais que teve no porto de São Francisco do Sul sua via de entrada mais importante.

O comércio internacional de Santa Catarina dependeu em grande medida dos portos de Itajaí e São Francisco do Sul. O primeiro obteve uma participação de cerca de $40 \%$ das importações e exportações desta UF. O segundo teve uma maior participação nas exportações da UF, ao redor de um terço.

O porto de Rio Grande foi o mais importante para o comércio exterior do Rio Grande do Sul, entre os portos da amostra, especialmente para as exportações. Aproximadamente $37 \%$ das importações e 70\% das exportações gaúchas, em 2002, passaram pelo porto de Rio Grande. Santos contribuiu com 4,5\% das importações do Rio Grande do Sul, em 2002. 
Mato Grosso do Sul utilizou o porto de Santos para importar mercadorias com uma intensidade maior do que os demais portos da amostra. Em especial, as principais mercadorias importadas por esta UF através de Santos foram máquinas e equipamentos mecânicos e zinco e suas obras. Os portos em nossa amostra são relativamente mais importantes para as exportações sul-mato-grossenses do que para as importações. Paranaguá e Santos foram as principais vias de saída, seguidos por Itajaí e São Francisco do Sul.

O comércio exterior de Goiás dependeu em grande medida dos portos de Santos e Vitória; Paranaguá tem um destaque menor. Acima de 40\% tanto das importações quanto das exportações de Goiás realizaram-se através de Santos, enquanto que em torno de 20\% das importações e 29\% das exportações da UF dependeram de Vitória.

O estado de Mato Grosso dependeu principalmente do porto de Paranaguá para importar bens. Nas exportações, o principal porto de saída foi Santos, seguido por Paranaguá e São Francisco do Sul; metade dos dois principais produtos exportados pela UF em 2002 (grãos de soja e resíduos da extração do óleo de soja) utilizara Santos como via de saída.

\subsection{Síntese}

Ao longo deste capítulo apresentamos informações acerca dos portos que fazem parte da amostra considerada. Estas informações servem, parcialmente, como justificativa para a escolha destes portos, pois, como é o objetivo dos parágrafos abaixo mostrar, eles estão distribuídos ao longo da costa brasileiro, de norte a sul, e são importantes para o comércio internacional da maioria das UFs brasileiras. 
As UFs do Nordeste utilizam majoritariamente os seguintes portos como via de entrada e saída de produtos: Belém (Maranhão), Fortaleza (Piauí, Ceará, Rio Grande do Norte), Suape (Rio Grande do Norte, Paraíba e Pernambuco), Salvador (Alagoas, Sergipe e Bahia) e Aratu (Bahia).

No Sudeste, o porto de Vitória é fundamental para o comércio exterior do Espírito Santo. Ele também é importante para Minas Gerais; UFs do Nordeste, particularmente, Rio Grande do Norte, Alagoas e Sergipe; e Goiás. Os portos localizados no Rio de Janeiro - Sepetiba e Rio de Janeiro - são voltados para o comércio do próprio Rio de Janeiro, ainda que o porto do Rio de Janeiro tenha relevância no abastecimento de Minas Gerais.

O comércio internacional de São Paulo depende fundamentalmente do porto de Santos. Embora vejamos fluxos entre esta UF e outros portos, que sejam importantes para os portos, eles não o são para São Paulo. Minas Gerais e o Centro-Oeste também têm no porto de Santos uma via importante de comércio com o exterior, todavia, do ponto de vista do porto, estes fluxos são menos importantes do que os paulistas.

O porto de Paranaguá é fundamental para o comércio internacional do Paraná, do Mato Grosso do Sul e Goiás. Em Santa Catarina, existem dois portos, Itajaí e São Francisco do Sul, que atendem ao comércio internacional da UF e do Paraná. O porto de Rio Grande é a principal via de entrada de mercadorias no Rio Grande do Sul, e através dele, uma parte das exportações do Paraná e São Paulo ocorre. 


\section{CAPÍTULO 3. Revisão da literatura}

Este capítulo traz uma discussão dos trabalhos relacionados à eficiência portuária ${ }^{7}$. Neste capítulo trataremos apenas dos trabalhos mais recentes, os quais percebemos ser possível separar em dois grupos que diferem no conceito de eficiência que buscam medir e na técnica empregada para tal. No primeiro grupo estão os trabalhos que utilizam a abordagem de fronteira estocástica e medem, portanto, a eficiência técnica ou econômica dos portos. No segundo grupo estão trabalhos que medem a eficiência relativa dos portos, ou seja, provêm medidas comparativas entre os portos; neste grupo dois tipos de abordagem foram encontradas: Data Envelopment Analysis (DEA) e uma metodologia alternativa baseada na análise de dados de comércio internacional introduzida por Blonigen \& Wilson (2006).

\subsection{Abordagem de fronteira estocástica}

Abaixo apresentamos a definição de eficiência técnica orientada para o produto ${ }^{8}$ adotada na literatura de fronteira estocástica, seguindo Kumbhakar et al (2000, pp. 43).

Definição. Um vetor $y \in P(x)$ é tecnicamente eficiente se, e somente se, $y^{\prime} \notin P(x)$ para todo $y^{\prime} \geq y$, onde $y=\left(y_{1}, \ldots, y_{M}\right) \in R_{+}^{M}$ é um vetor não negativo de produtos, $x=\left(x_{1}, \ldots, x_{N}\right) \in R_{+}^{N}$ é um vetor não negativo de insumos e $P(x)$ representa os conjuntos de produto, ou seja, os produtos que podem ser obtidos com cada vetor de insumos $x \in R_{+}^{N}$.

\footnotetext{
${ }^{7}$ González et al (2007) apresenta uma extensiva revisão bibliográfica do assunto, contendo inclusive um breve histórico.

${ }^{8}$ Concentraremos a atenção na definição de eficiência técnica orientada para o produto e, posteriormente, na medida de eficiência técnica orientada para o produto porque estas são mais relevantes na pesquisa empírica.
} 
Em outras palavras, a definição anterior afirma que um vetor de produção $y$ é tecnicamente eficiente se, mantendo fixo o vetor de insumos $x$, não é possível aumentar a quantidade produzida de qualquer um dos produtos. Ainda seguindo Kumbhakar et al (2000, pp. 46), a partir desta definição de eficiência técnica orientada para produto podemos definir um medida de eficiência técnica orientada para produto para o caso em que apenas um produto é produzido utilizando vários insumos.

Definição. Se apenas um produto é produzido, uma medida de eficiência técnica orientada para produto é dada pela função $T E=[\max \{\phi: \phi y \leq f(x)\}]^{-1}$, onde $f(x)=\max \{y: y \in P(x)\}$ é a fronteira de produção.

O inverso de $T E$ mede qual a expansão possível do produto dada a quantidade de insumos. Graficamente, considere o caso de um produtor que esteja no ponto $A$ do Gráfico 3.1. O produto poderia ser expandido $\phi^{A}$ vezes dada a quantidade fixa de insumos consumida. A eficiência técnica atribuída ao produtor $A$ é $T E^{A}=\left(\phi^{A}\right)^{-1}$. Quanto maior for o aumento do produto possível, i.e. quanto maior for $\phi$, menor será $(\phi)^{-1}$, a eficiência técnica do produtor. Observe ainda que $T E \leq 1$. 


\section{Gráfico 3.1. Medida de eficiência técnica orientada para produto, um único produto}

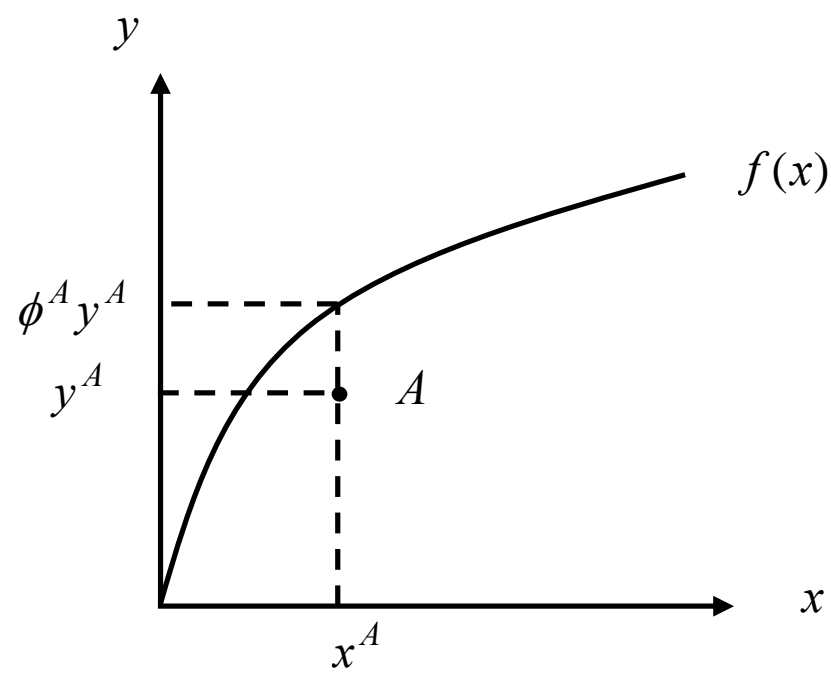

Fonte: Kumbhakar et al (2000).

Note que o padrão segundo o qual a eficiência é medida é a fronteira de produção (não há nenhuma hipótese sobre o comportamento do produtor). Diferentemente da medida de eficiência técnica, o padrão de comparação na medida de eficiência de custo incorpora um objetivo comportamental, a minimização de custos. Abaixo reproduzimos a medida de eficiência de custo apresentada em Kumbhakar et al (2000) pp. 51.

Definição. Uma medida de eficiência de custo é a função $C E(y, x, w)=c(y, w) / w^{T} x$, onde $w$ é o vetor de preços dos insumos e $c(y, w)$ representa a fronteira de custo.

A eficiência de custo pode ser decomposta em eficiência técnica e alocativa, a última sendo a falha do produtor em usar os insumos na proporção adequada dados seus preços. Ou seja, para uma dada quantidade de produto que se deseja alcançar, existe um conjunto de combinação dos fatores que são tecnicamente eficientes. Se o produtor não utilizar uma combinação que pertença a este conjunto, será ineficiente do ponto de vista dos custos, pois utilizará mais insumos do que o necessário para produzir a quantidade almejada de produto. Ainda que a 
combinação de insumos pertença ao conjunto das combinações tecnicamente eficientes, um produtor pode ser ineficiente do ponto de vista dos custos se não escolher a combinação que, aos preços dados dos insumos, minimiza os custos.

Os modelos econométricos de fronteira de produção estocástica seguem a especificação [Kumbhakar et al (2000), pp. 65]:

$$
y_{i}=f\left(x_{i} ; \beta\right) \cdot \exp \left\{v_{i}\right\} \cdot T E_{i}
$$

na qual, $y_{i}$ é o produto do produtor $i=1, \ldots, I ; x_{i}$ é o vetor de $\mathrm{N}$ insumos usados pelo produtor $i$; $f\left(x_{i} ; \beta\right)$ é a fronteira de produção $\operatorname{com} \beta$, o vetor de parâmetros tecnológicos a serem estimados; $v_{i}$ é um termo aleatório simétrico; e $T E_{i}=\exp \left\{-u_{i}\right\}, u_{i} \geq 0$, é a eficiência técnica orientada para produto do produtor $i$. Logo,

$$
T E_{i}=\frac{y_{i}}{f\left(x_{i} ; \beta\right) \cdot \exp \left\{v_{i}\right\}} \leq 1
$$

A vantagem da metodologia de fronteira de produção estocástica é permitir que a produção seja afetada por elementos fora do controle dos produtores, sem que isto seja considerado ineficiência.

Para dados em cross-section o modelo anterior é estimado por máxima-verossimelhança, admitindo-se alguma distribuição para $u_{i}$ definida apenas para valores positivos (meianormal, exponencial, normal truncada e gama estão entre as mais exploradas) e alguma 
distribuição simétrica para $v_{i}$. Outra hipótese relevante é de que $u_{i}$ tem distribuição independente de $x_{i}$. O uso de dados em painel tem a vantagem de possibilitar em alguns casos dispensar ambas as hipóteses.

Para o caso de um único produto, a especificação do modelo de fronteira de custo estocástica segue [Kumbhakar et al (2000), pp. 137]:

$$
E_{i}=c\left(y_{i}, w_{i} ; \beta\right) \cdot \exp \left\{v_{i}\right\} .\left(C E_{i}\right)^{-1} .
$$

Onde $E_{i}$ é a gasto do produtor $i$ e $C E_{i}=\exp \left(-u_{i}\right)$ é a medida de eficiência de custo.

Estache et al (2002) ajusta um modelo de fronteira de produção estocástica para um conjunto de portos mexicanos. O objetivo é duplo: prover os encarregados de fazer a regulação do setor de uma medida da eficiência dos portos através da qual a comparação entre os portos pode ser realizada e obter a variação desta para testar os efeitos das mudanças promovidas pelo governo mexicano no setor. Os autores utilizam dados em painel para o período 1996-1999 e estimam funções de produção do tipo trans-log e Cobb-Douglas.

O produto da atividade portuária é medido pelo volume de mercadorias manuseadas (em toneladas), embora os autores observem que seria mais adequado trabalhar com o porto como uma unidade produtora de múltiplos produtos, já que o manuseio de cada tipo de carga é um produto distinto e há outros serviços providos pelo porto. Os insumos da função de produção são trabalho e capital, sendo o primeiro medido pelo número de trabalhadores no porto e o segundo, pelo comprimento das docas concedidas pelo governo. Destacamos dois resultados do modelo: 1) os autores não encontraram evidências de que a fronteira de produção dos 
portos mexicanos no período considerado fosse estocástica; 2) olhando os resultados para a função de produção Cobb-Douglas, este conjunto de portos mexicanos apresenta retornos decrescentes a escala.

O primeiro resultado chama a atenção, pois um dos motivos de permitir que a fronteira seja estocástica é não deixar que erros de medida dos insumos comprometam os resultados da eficiência. A medida adotada por Estache et al (2002) do capital do porto foi escolhida de maneira arbitrária e, potencialmente, não mede fielmente este insumo. Como a fronteira estimada não é estocástica, toda diferença entre a produção do porto e a fronteira, inclusive aquela que é resultado de uma medida incorreta do capital do porto, é considerada ineficiência. Desta maneira, as estimativas de eficiência podem ter sido comprometidas.

Já o segundo resultado, evidência de retornos decrescentes de escala, aponta que congestionamentos - seja de navios a espera para entrar ou sair do porto ou das mercadorias em terra para o deixarem - restringem a produtividade do porto. Em outras palavras, os retornos a escala são decrescentes porque o espaço físico é um insumo fixo para o porto.

A metodologia de fronteira estocástica também é utilizada por Cullinane et al (2003) para avaliar se privatização e desregulamentação tiveram um efeito positivo sobre a eficiência dos terminais de contêineres coreanos. Os insumos considerados neste trabalho são: dois tipos de trabalho, medidos pela remuneração total dos executivos e o total de salários pagos aos empregados; e dois bens de capital, medidos pelo valor líquido do equipamento fixo, prédios e terras e pelo valor líquido do equipamento móvel e para manuseio de carga. O produto é medido pelo valor da receita da provisão dos serviços do terminal, excluindo a receita de 
vendas de propriedades. A forma da função de produção escolhida é Cobb-Douglas e os autores estimam um modelo com dados em cross-section e outro com dados em painel.

Os trabalhos descritos anteriormente analisam a questão da eficiência portuária do ponto de vista da produção. Ainda na abordagem de fronteira estocástica, Barros (2005), por outro lado, estima uma fronteira estocástica de custos para um conjunto de portos portugueses, de maneira a identificar "melhores práticas” na administração dos portos. Para tanto, Barros (2005) usa um painel de dados para dez portos portugueses cobrindo o período de onze anos (1990-2000). Seguindo a teoria econômica, a estimação da função custo requer informações sobre preços dos insumos, custo total e produção. Barros (2005) considera dois insumos, capital e trabalho, sendo o preço do primeiro aproximado pela razão dos ganhos pelo valor das propriedades e do segundo medido pela divisão do gasto total com salários pelo número de trabalhadores equivalentes. O produto é medido pelo total de carga e número de embarcações. A forma funcional escolhida por Barros (2005) é a trans-log e a inclusão de um termo de tendência anual permite que sejam computados separadamente três tipos de progresso técnico: mudança tecnológica pura, equivalente a um deslocamento da função custo na direção da origem; mudança tecnológica não neutra, ou seja, mudanças na sensibilidade do custo total às mudanças nos preços dos fatores; e, por fim, mudança tecnológica relacionada ao aumento da escala.

O problema com a abordagem de Barros (2005) é, mais uma vez, não considerar cada tipo de carga manuseada pelo porto (granel líquido, granel sólido, carga geral conteinerizada ou solta) e outros serviços prestados pelo porto, por exemplo, armazenagem, como produtos distintos cuja combinação ótima de fatores que minimiza o custo de produzi-los é distinta. 
De forma geral, a literatura que aborda o problema de estimar a eficiência portuária através de fronteira estocástica enfrenta os seguintes problemas. Em primeiro lugar, a definição do produto da atividade portuária é problemática, mais precisamente, não há consenso sobre o que é o produto de um porto ou que medida dele deve ser usada. O ideal é, como notado, considerar diferentes produtos dos portos separadamente. Mais ainda, a provisão de produtos da atividade portuária como a quantidade de carga manuseada ou número de contêineres carregados devem ser considerados, do ponto de vista da eficiência, no tempo.

As definições dos insumos enfrentam o mesmo problema. A omissão recorrente de uma medida de espaço físico das áreas relevantes do porto (fator terra) também é um problema dos trabalhos citados, já que este fator interfere na capacidade da produção dos portos. O problema de definir adequadamente produto(s) e insumos é agravado por outra limitação desta abordagem: o elevado volume de informações necessárias para implementá-la. Em alguns casos as restrições nas informações podem levar os autores a utilizarem medidas de insumos que de fato não contribuem para a produção daquilo que foi definido como produto.

Devemos observar ainda que o fato de um porto ser relativamente mais eficiente não significa necessariamente que sua contribuição para os custos de transporte totais de uma mercadoria será menor, tudo o mais constante. Isto porque as hinterlands e as vorlands dos portos, respectivamente, suas áreas de influência terrestre e marítima, não são sobrepostas dando margem aos portos para terem algum poder de mercado. Por isso, os portos não operam em um ambiente de concorrência perfeita, logo o preço cobrado pelo produto e o custo de produzi-lo não é mesmo, embora guardem certa relação entre si. 


\subsection{Medidas relativas de eficiência portuária - abordagem DEA $^{9}$}

A metodologia de DEA é não paramétrica e permite que mais de um produto seja produzido a partir de vários insumos. As medidas de eficiência estimadas por DEA são relativas. A idéia básica deste método foi retirada da engenharia que define a eficiência de uma máquina ou processo como a razão entre produto e insumo, razão esta que é considerada menor ou igual a um devido à perda de energia.

Em DEA cada observação na amostra é denominada DMU (decision making unit). Seja $h_{i}$ a razão entre uma combinação linear dos produtos, ponderados por um vetor $u$, e uma combinação linear dos insumos, ponderados por um vetor $v$, para a DMU $i$. A abordagem de DEA obtém os vetores $u$ e $v$ para cada DMU $i$ como a solução do problema:

$\operatorname{Max} h_{i}=\frac{u Y_{i}}{v X_{i}}=\frac{u_{1} Y_{1 i}+u_{2} Y_{2 i}+\ldots+u_{n} Y_{n i}}{v_{1} X_{1 i}+v_{2} X_{2 i}+\ldots+v_{m} X_{m i}}$, sujeito à

$h_{j}=\frac{u Y_{j}}{v X_{j}}=\frac{u_{1} Y_{1 j}+u_{2} Y_{2 j}+\ldots+u_{n} Y_{n j}}{v_{1} X_{1 j}+v_{2} X_{2 j}+\ldots+v_{m} X_{m j}} \leq 1$, para toda DMU $j \neq i$

Onde $Y$ é o vetor de produtos e $X$ é o vetor de insumos. Se $h_{i}^{*}$, o valor da razão no ponto de máximo, é igual a um, então a DMU $i$ é eficiente em relação às demais; caso $h_{i}^{*}<1$ então

\footnotetext{
${ }^{9}$ Baseado em Emrouznejad (1995).
} 
existe(m) alguma(s) DMU mais eficiente(s) do que $i$. Existem várias metodologias para resolver este problema. Destacamos, entre elas, o modelo CCR, que admite exclusivamente retornos constantes de escala, e o modelo aditivo, que permite retornos crescentes de escala.

Tongzon (2001) aplica a metodologia de DEA a um conjunto de portos (quatro australianos e doze de outros países que lidam com carga conteinerizada) de maneira a obter estimativas comparáveis da eficiência destes portos para o ano de 1996. Ele supõe dois produtos, a saber, o número total de contêineres carregados e descarregados em unidades equivalentes de 20-pés (TEUs) e o número de contêineres movidos por hora trabalhada por embarcação.

Os insumos utilizados para produzir os dois produtos mencionados dividem-se em três categorias: capital, trabalho e terra. Na primeira categoria, Tongzon (2001) inclui os seguintes insumos, número de berços, guindastes e rebocadores. Como proxy para o trabalho, Tongzon (2001) usa o número de empregados da autoridade portuária, já que a quantidade correta (número de estivadores) é de difícil acesso. A área do terminal portuário é a medida do insumo terra. Tongzon (2001) inclui ainda o tempo de espera como um sexto fator de produção.

A escolha do autor de incluir o tempo de espera entre os insumos gera conseqüências indesejáveis tendo em vista os objetivos de seu trabalho. Um dos mais importantes resultados de uma combinação menos eficiente dos fatores “reais” de produção (capital, trabalho e terra) é o aumento relativo do tempo de espera. Isto é, um porto não é ineficiente apenas quando falha em conseguir produzir a mesma quantidade daqueles dois produtos, dispondo da mesma quantidade de fatores que os outros portos, mas também é ineficiente se, para atingir o mesmo patamar de produção dos outros sob condições idênticas, leva mais tempo na forma de tempo 
de espera. Se este é incluído como fator de produção, então a parcela da ineficiência atribuída a ele aparecerá no modelo como produto marginal do insumo tempo de espera. Logo, a medida estimada de eficiência não estaria completa, o que iria prejudicar a comparação entre os portos. Em outras palavras, um porto pode ser considerado relativamente mais eficiente quando na verdade não é se considerarmos o tempo de espera que impõe às embarcações.

\subsection{Medidas relativas de eficiência portuária - abordagem de Blonigen \& Wilson (2006)}

Blonigen \& Wilson (2006) partem de dados das importações dos Estados Unidos realizadas através de portos. O governo americano fornece uma estatística denominada "import charges" que é a soma dos custos incorridos para trazer as mercadorias para os EUA, excluindo as tarifas cobradas pelo governo. Este custo pode ser decomposto em três partes: 1) o custo no porto de origem, 2) frete marítimo e 3) custo do porto de destino nos EUA. Os componentes 1 e 3 são ligados à eficiência dos portos estrangeiros e norte-americanos, respectivamente.

Os autores propõem uma regressão para separar cada um destes elementos ${ }^{10}$. A variável dependente são as “import charges” (em logaritmo). As variáveis incluídas no modelo para separar o componente de frete marítimo das "import charges” são: logaritmo da distância em milhas náuticas entre os portos; logaritmo do peso transportado; o logaritmo da razão entre o valor em dólares e o peso comercializado, que visa capturar o custo com seguro; a porcentagem dos carregamentos entre dois portos de um produto que usa contêiner; o logaritmo do volume total (somando todos os tipos de mercadoria) transportado entre pares de portos; variáveis de interação entre a variável de contêiner, peso e valor por peso; logaritmo da diferença entre as mercadorias importadas e exportadas, quando esta diferença é positiva e

\footnotetext{
${ }^{10}$ Blonigen \& Wilson (2006) usam o trabalho de Clark et al (2004), mencionado na Introdução, como base para determinar as variáveis de controle.
} 
zero caso contrário e logaritmo da diferença entre as mercadorias exportadas e importadas, quando esta diferença é positiva e zero caso contrário.

Para obter medidas de eficiência dos portos são adicionadas dummies para os portos norteamericanos (entrada) e do resto do mundo (saída). Os autores optaram por excluir a dummy do porto de Roterdam e do porto de Oakland, portanto, as eficiências calculadas para os portos do resto mundo são relativas à Roterdam e para os portos norte-americanos, em relação à Oakland.

As estimativas de eficiência portuária de Blonigen \& Wilson (2006) mostram um padrão. Os portos mais eficientes são na maior parte das vezes europeus ou japoneses. Em seguida aparecem os portos de países do sudeste da Ásia, como Taiwan e Coréia do Sul. Os portos mais ineficientes são principalmente chineses ou da América Central. Três portos brasileiros aparecem na amostra: Rio Grande, Rio de Janeiro e São Paulo (provavelmente trata-se do porto de Santos). Os três mostraram-se menos eficientes do que o porto de Roterdam. Utilizar o porto de Rio Grande ao invés de Roterdam provoca um aumento de aproximadamente 9\% nas “import charges”. No caso de Rio de Janeiro e São Paulo esta porcentagem chega a 17,4 e 19,3\%, respectivamente.

Assim, como a abordagem de DEA, a metodologia sugerida por Blonigen \& Wilson (2006) computa medidas relativas de eficiência. A metodologia de Blonigen \& Wilson (2006) tem três vantagens sobre DEA: 1) ela considera choques estocásticos, ou seja, não está sujeita como a abordagem de DEA a classificar como ineficiência um resultado que é devido a um choque aleatório; 2) permite que sejam feitos testes estatísticos sobre os resultados; 3) a metodologia de Blonigen \& Wilson (2006) utilza dados de comércio internacional que são 
amplamente coletados e disponibilizados pelos governos, ao contrário, de DEA e os trabalhos que usam fronteira estocástica que necessitam de informações dos portos que, em geral, não estão disponíveis.

Embora tenha as vantagens mencionadas, o trabalho de Blonigen \& Wilson (2006) apresenta falhas na econometria utilizada. No próximo capítulo, estas falhas são enunciadas e uma correção é sugerida. A metodologia melhorada é então aplicada aos dados de importações brasileiras. 


\section{CAPÍTULO 4. Estimação dos custos logísticos do comércio internacional brasileiro}

Neste capítulo aplicaremos a metodologia de Blonigen \& Wilson (2006) ao Brasil de modo a obtermos estimativas do impacto dos custos portuários no custo de transporte total e medidas relativas de eficiência portuária. Na seção 4.1, apresentamos a metodologia com correção para dois problemas que Blonigen \& Wilson (2006) ignoram: endogeniedade e viés de seleção da amostra. Em seguida, na seção 4.2, os resultados são apresentados.

\subsection{Metodologia e Banco de Dados}

Uma rede de transporte é formada por links, ou ligações, vias pelas quais as mercadorias são transportadas, e nós, isto é, os pontos em que as ligações se encontram e ocorre a transferência das mercadorias entre as ligações e, geralmente, a troca da modalidade de transporte (modal). O porto é, em uma rede de transporte, o nó em que as mercadorias passam do modal terrestre para o marítimo. A grande maioria das mercadorias importadas pelo Brasil é transportada por via marítima até o país, entra por um dos portos na costa e segue por via terrestre ao seu destino; as exportações realizam o percurso no sentido inverso.

Logo, podemos separar três componentes dos custos logísticos: o custo do transporte interno, principalmente rodoviário, o custo no porto de fazer a transferência entre os modais e de armazenagem e o custo do transporte marítimo. A metodologia adotada no presente trabalho seguiu Blonigen \& Wilson (2006), com alterações nos procedimentos econométricos, para separar a contribuição de cada um destes elementos para o custo de transporte. 
Foram usados dados das importações brasileiras. No lugar de “import charges” utilizamos o logaritmo natural da diferença entre o valor CIF e FOB das importações. O valor CIF das importações foi obtido do Comtrade (ONU) e o FOB do MDIC. Os dados do Comtrade são detalhados por país de origem e tipo de mercadoria, mas agregados para o Brasil; enquanto que as informações do MDIC estão desagregadas por país de origem, tipo de mercadoria e estado de destino no Brasil. Para conformar as duas fontes, na base de dados do MDIC, para cada país de origem das importações brasileiras e tipo de mercadoria, calculamos a proporção delas que se dirigia a cada estado. Usamos esta proporção para desagregar os dados do Comtrade.

O valor CIF inclui o valor do bem na transação, o valor dos serviços prestados para levar o bem até a fronteira do país exportador e o valor dos serviços necessários para levar os produtos da fronteira do país exportador para a fronteira do país importador. O valor FOB, por sua vez, inclui o valor do bem na transação e o valor dos serviços prestados para levar o bem até a fronteira do país exportador. Logo, a diferença entre o valor CIF e FOB de um bem importado é igual ao custo de levá-lo da fronteira do exportador à do importador, que deve conter um componente de custo do porto de origem, frete marítimo e custo associado ao porto de destino.

Não tivemos acesso à informação do porto de procedência da importação apenas do país de origem, por isso não temos como incluir uma dummy para o porto de origem da maneira feita em Blonigen \& Wilson (2006). Admitimos que o componente devido ao porto de origem no exterior faça parte do custo de levar as mercadorias até a fronteira do país exportador e, portanto, tenha sido eliminado pelo cálculo da diferença CIF-FOB. O custo de transporte interno - custo de levar a mercadoria da fronteira do Brasil, ou seja, do porto de entrada, até o 
local de consumo - não está presente, consequentemente não é preciso incluir variáveis de controle para ele.

As observações são caracterizadas por quatro elementos: estado no Brasil de destino (índice r), país de origem (índice $s$ ), tipo de mercadoria importada (Sistema Harmonizado, seis dígitos, índice $i$ ) e porto de entrada (índice $p$ ). Portanto, a variável dependente, que iremos denotar por $y_{1 i r s p}$, é o custo de levar a mercadoria $i$ - importada pelo estado $r$ - da fronteira do país exportador $s$ ao porto $p$ no Brasil, que incluí o frete marítimo e o custo portuário. Coletamos dados do ano de 2002 para aqueles treze portos brasileiros já mencionados (Rio Grande, Itajaí, São Francisco do Sul, Paranaguá, Santos, Vitória, Sepetiba, Rio de Janeiro, Salvador, Aratu, Suape, Fortaleza e Belém). A equação que desejamos estimar é:

$$
y_{1 i r s p}=\boldsymbol{x}_{i r s p} \boldsymbol{\beta}+\varepsilon_{i r s p},
$$

onde $\boldsymbol{x}_{\boldsymbol{i r s p}}$ é o vetor de variáveis explicativas incluindo as variáveis de controle para o custo do frete marítimo e as dummies portuárias, $\beta$ o vetor de parâmetros e $\varepsilon_{\boldsymbol{i r s p}}$ um termo de erro aleatório. A seguir, descrevemos as variáveis explicativas.

A função custo do transporte marítimo possui uma parcela fixa e outra variável. Os custos fixos incluem os custos de capital (pagamento do armador para efetuar a compra da embarcação) e gastos fixos, por exemplo, gastos com a tripulação, manutenção e seguros. Os custos variáveis incluem os gastos com combustíveis e os chamados gastos de escala (custo das operações portuárias) ${ }^{11}$. As variáveis (em logaritmo natural) peso importado em $\mathrm{kg}(\mathrm{Lnkg})$

\footnotetext{
${ }^{11}$ Vieira (2003, pp. 83-84).
} 
e distância euclidiana em km do porto de desembarque no Brasil ao país de origem dos bens (Lndist_parceiro) foram inseridas com a intenção de captar a parcela variável dos custos do transporte marítimo; o sinal esperado é positivo para ambas.

As variáveis Lnvolume e Sqlnvolume, respectivamente o logaritmo natural do volume total de mercadorias transportas do país de origem das importações ao porto de destino no Brasil e seu quadrado, têm por objetivo representar as economias de escalas decorrentes da existência de custos fixos. Conforme o volume de bens transportados aumenta, a existência de custos fixos implica em redução no custo médio, possibilitando redução do custo de frete. Por isso esperamos que Lnvolume tenham um sinal negativo. Por outro lado, dada a capacidade dos portos brasileiros e das companhias de transporte marítimo, o aumento da procura por transporte entre um país estrangeiro e um dos portos leva a problemas de congestionamento. Sendo assim, incluímos Sqlnvolume, cujo sinal esperado é positivo.

Como notado acima, a variável dependente não incorpora o custo de transportar a mercadoria importada do porto ao estado de destino final. Mesmo assim, optamos por incluir também a distância entre ao estado importador e o porto de importação (Lndist_uf e Sqlndist_uf) de forma a capturar externalidades de proximidade, ou seja, as variações no poder de barganha em função da proximidade em relação ao porto. Outro fator que influência o custo do frete marítimo é o custo com seguro; para captar este componente incluímos a variável Lnvalor/peso e, como o seguro aumenta com o valor unitário da mercadoria transportada, Lnvalor/peso deve ter sinal positivo.

Além destas variáveis incluímos dummies para o tipo de mercadoria e para o porto (parte do custo variável denominada de custo de escala). Para os tipos de mercadoria usamos a 
classificação dos capítulos da Nomenclatura Comum do Mercosul (NCM). A intenção ao incluir dummies para as mercadorias foi controlar para os efeitos da especialização dos portos e dos diferenciais dos custos de transportar certas mercadorias devido a características inerentes a elas. A dummy de mercadoria escolhida para ficar ausente do modelo foi a do capítulo correspondente aos cereais. As dummies dos portos captam o diferencial de custo específico de cada porto. Optamos por omitir a dummy para o porto de Santos, de modo que o coeficiente da dummy de um porto $p$ qualquer multiplicado por 100 seja interpretado como a variação percentual nos custos de importar uma mercadoria de um dado país estrangeiro para certo estado no Brasil pelo porto $p$ em relação ao custo de importá-la pelo porto de Santos ${ }^{12}$.

Até este ponto seguimos Blonigen \& Wilson (2006) com diferenças apenas devido à disponibilidade de dados. No entanto, já apontamos que esta metodologia possui dois problemas: endogeneidade e viés de seleção da amostra. Comecemos tratando do primeiro. A quantidade importada depende do próprio custo dos portos que está incorporado na variável dependente, sendo assim, as variáveis Lnkg, Lnvolume, Sqlnvolume e Lnvalor/peso ${ }^{13}$ são endógenas. Logo, podemos separar o vetor $\boldsymbol{x}_{\boldsymbol{i r s p}} \boldsymbol{\beta}$ em dois componentes:

$$
x_{i r s p} \beta=z_{1 i r s p} \delta+y_{2 i r s p} \alpha
$$

O vetor $\boldsymbol{z}_{1 \text { lirsp }}$ contém as variáveis exógenas: Lndist_parceiro, Lndist_uf, Sqlndist_uf, e as dummies para o tipo de mercadoria; e $\boldsymbol{y}_{2 i r s p}$ contém as variáveis endógenas listadas. Logo, a equação (4.1) pode ser reescrita como:

\footnotetext{
12 A forma precisa formalmente de interpretar os coeficientes das dummies dos portos seria calcular seu exponencial. A maneira descrita no texto, e da qual nos utilizamos ao longo do trabalho, é uma aproximação.

13 As dummies dos portos também são variáveis endógenas visto que a escolha do porto pelo qual a importação ocorre também depende dos custos dos portos. Trataremos deste problema em conexão com a questão correlata de viés de seleção da amostra.
} 
$y_{1 i r s p}=\boldsymbol{z}_{1 i r s p} \boldsymbol{\delta}+\boldsymbol{y}_{2 i r s p} \boldsymbol{\alpha}+\varepsilon_{\text {irsp }}$

O passo seguinte consiste em encontrar variáveis instrumentais para as variáveis endógenas. O modelo gravitacional de comércio internacional tem grande sucesso empírico em explicar o volume de comércio entre dois países [ver Leamer e Levinsohn (1995)]. Além disso, diferentes teorias de comércio internacional dão suporte ao modelo gravitacional de modo que supor sua valida não apresenta restrição sob este ponto de vista [ver Evenett e Keller (1998) para fontes sobre este tema]. Em razão destes predicados, assumimos que $\boldsymbol{y}_{2 i r s p}$ é explicado por um modelo gravitacional:

$y_{2 i r s p}=z_{i r s p} \delta_{2}+v_{2 i r s p}$

A matriz $z_{i r s p}$, seguindo a literatura de modelos gravitacionais, inclui as variáveis em $\boldsymbol{z}_{1 \text { irsp }}$ mais as variáveis logaritmo natural do PIB per capita do estado de destino no Brasil das mercadorias e seu quadrado (respectivamente, Lnpib_uf e Sqlnpib_uf), o logaritmo natural do PIB do país de origem e seu quadrado (respectivamente, Lnpib_parceiro e Sqlnpib_parceiro), e o logaritmo natural da população e área do país de origem (respectivamente, Lnpop_parceiro e Lnárea_parceiro); assim, podemos dividir $\boldsymbol{z}_{\text {irsp }}$ em dois termos: $\boldsymbol{z}_{\text {irsp }} \boldsymbol{\delta}_{2}=\boldsymbol{z}_{\text {lirsp }} \boldsymbol{\delta}_{21}+\boldsymbol{z}_{2 i r s p} \boldsymbol{\delta}_{22} ; \delta_{2}$ é a matriz de coeficientes e $\boldsymbol{v}_{2 i r s p}$ é um vetor de termos aleatórios. Portanto, podemos usar as variáveis em $\boldsymbol{z}_{2 i r s p}$ como instrumentos.

O Quadro 4.1 resume as variáveis utilizadas. 


\section{Quadro 4.1 - Variáveis usadas no modelo}

\begin{tabular}{|c|c|c|}
\hline Variável & Descrição & Fonte \\
\hline Lnkg & Logaritmo natural do peso (em Kg) importado. & $\begin{array}{l}\text { MDIC, } \\
\text { Aliceweb. }\end{array}$ \\
\hline Lnvolume & $\begin{array}{l}\text { Logaritmo natural do total das mercadorias importadas entre o porto de } \\
\text { entrada no Brasil e o país de origem da importação. }\end{array}$ & $\begin{array}{l}\text { MDIC, } \\
\text { Aliceweb. }\end{array}$ \\
\hline Sqlnvolume & Quadrado de Lnvolume. & $\begin{array}{l}\text { MDIC, } \\
\text { Aliceweb. }\end{array}$ \\
\hline Lnvalor/peso & $\begin{array}{l}\text { Logaritmo natural da razão valor importado (US\$ FOB) por peso } \\
\text { importado (Kg) }\end{array}$ & $\begin{array}{l}\text { MDIC, } \\
\text { Aliceweb. }\end{array}$ \\
\hline Lndist_parceiro & $\begin{array}{l}\text { Logaritmo natural da distância em linha reta do porto a capital do país de } \\
\text { origem da importação }(\mathrm{Km}) \text {. }\end{array}$ & $\begin{array}{l}\text { Cálculos } \\
\text { próprios. }\end{array}$ \\
\hline Lndist_uf & $\begin{array}{l}\text { Logaritmo natural da distância em linha reta do porto a capital do estado } \\
\text { de destino da importação }(\mathrm{Km}) \text {. }\end{array}$ & $\begin{array}{l}\text { Cálculos } \\
\text { próprios. }\end{array}$ \\
\hline Sqlndist_uf & Quadrado de Lndist_UF. & $\begin{array}{l}\text { Cálculos } \\
\text { próprios. }\end{array}$ \\
\hline $\begin{array}{l}\text { Dummies para os } \\
\text { portos }\end{array}$ & $\begin{array}{l}\text { Doze variáveis dummy assumindo valor um quando o porto utilizado para } \\
\text { importação for o correspondente a dummy e zero caso contrário. }\end{array}$ & $\begin{array}{l}\text { Cálculos } \\
\text { próprios. }\end{array}$ \\
\hline $\begin{array}{l}\text { Dummies para os } \\
\text { bens }\end{array}$ & $\begin{array}{l}\text { Novente e nove variáveis dummy assumindo valor um quando o bem } \\
\text { importado for o correspondente a dummy e zero caso contrário. Os bens } \\
\text { foram classificados de acordo com a classificação dos capítulos da NCM. }\end{array}$ & $\begin{array}{l}\text { Cálculos } \\
\text { próprios. }\end{array}$ \\
\hline Lnpib_parceiro $^{*}$ & $\begin{array}{l}\text { Logaritmo natural do PIB do país de origem da importação (US\$ paridade } \\
\text { do poder de compra). }\end{array}$ & $\begin{array}{l}\text { Penn World } \\
\text { Tables. }\end{array}$ \\
\hline Sqlnpib_parceiro $^{*}$ & Quadrado de Lnpib_parceiro. & $\begin{array}{l}\text { Penn World } \\
\text { Tables. }\end{array}$ \\
\hline Lnpop_parceiro* & Logaritmo natural da população do país de origem da importação. & $\begin{array}{l}\text { Banco } \\
\text { Mundial. }\end{array}$ \\
\hline Lnárea_parceiro $^{*}$ & Logaritmo natural da área do país de origem da importação. & $\begin{array}{l}\text { Banco } \\
\text { Mundial. }\end{array}$ \\
\hline Lnpib_uf $^{*}$ & Logaritmo natural do PIB do estado brasileiro de destino da importação. & IPEA. \\
\hline Sqlnpib_uf* & Quadrado de Lnpib_uf. & IPEA. \\
\hline
\end{tabular}

* Variáveis instrumentais. 
Agora, trataremos do problema de viés de seleção da amostra. Os custos portuários determinam qual porto será a via de entrada das mercadorias ou que alguns portos não serão usados para certos fluxos. Por exemplo, considere o problema de uma firma ou agente no estado $r$ do Brasil que deseja importar um bem do país estrangeiro $s$. Para tanto, a firma ou agente deve escolher o(s) porto(s) por onde o bem deve entrar no Brasil. Dado a quantidade importada, as características da carga etc. têm-se para cada porto o custo de importá-la. Para alguns portos, o custo da firma ou agente no estado $r$ importar o bem do país $s$ será tão elevado que eles não serão utilizados como via de entrada. Assim, no conjunto de transações entre estados brasileiros e países estrangeiros através de um porto estão ausentes aquelas para as quais o custo do porto foi tão elevado que fez os agentes escolherem outro(s) porto(s). Seguindo este raciocínio, podemos afirmar também que as dummies para os portos são variáveis endógenas.

Seja $y_{3 i r s p}$ uma variável binária igual a 1 caso o porto $p$ for usado pelo estado $r$ para importar a mercadoria $i$ do país $s$; e 0 , caso contrário. Assim, acrescentamos mais treze equações, sendo uma para cada um dos treze portos na amostra:

$$
y_{3 i r s p}=1\left(z_{i r s p} \boldsymbol{\delta}_{3 p}+v_{3 p}>0\right)
$$

Heckman (1979) demonstra que o viés de seleção da amostra equivale ao viés de omissão de variável relevante e que é possível corrigir este problema acrescentando a equação a ser estimada $\lambda_{i r s p}$, a razão inversa de Mills, cuja fórmula é dada por: 
$\lambda_{i r s p}=\frac{\phi\left(-\boldsymbol{z}_{i r s p} \boldsymbol{\delta}_{3 p} / \sigma_{3 p}^{1 / 2}\right)}{\left[1-\Phi\left(-\boldsymbol{z}_{\text {irsp }} \boldsymbol{\delta}_{3 p} / \sigma_{3 p}^{1 / 2}\right)\right]}$,

onde $\phi($.$) e \Phi($.$) são as funções densidade e distribuição da normal padrão e \sigma_{3 p}$ é a variância de $v_{3 p}$.

A razão inversa de Mills pode ser obtida através da estimação de um modelo probit, por sua vez, é obtida a partir da estimação de um modelo probit. Wooldridge (2002) consolida um procedimento para lidar com o problema de estimar um modelo com variáveis explicativas endógenas e viés de seleção que utiliza dois estágios de mínimos quadrados e o procedimento de Heckman (1979) para corrigir viés de seleção de amostra. As hipóteses necessárias para realizar o procedimento sugerido por Wooldridge (2002) são;

(a) $\left(z, y_{3}\right)$ é sempre observado, $\left(y_{1}, y_{2}\right)$ são observados quando $y_{3 i r s p}=1$.

(b) $\left(\varepsilon, v_{3 p}\right)$ é independente de $\boldsymbol{z}$, para todo $p$.

(c) $v_{3 p}$ tem distribuição normal padrão, para todo $p$.

(d) $E\left(\varepsilon / v_{3 p}\right)=\gamma \cdot v_{3 p}$, para todo $p$.

(e) $E\left(z^{\prime} v_{2}\right)=\mathbf{0}$. 
Admitindo as hipóteses (a)-(e) o procedimento descrito por Wooldridge (2002) para estimar o modelo tem dois passos:

Passo 1. Obtenha $\boldsymbol{\delta}_{3 \boldsymbol{p}}$ de um probit de $y_{3 i r s p}$ em $\boldsymbol{z}$, e calcule a razão inversa de Mills $\left(\lambda_{\text {irsp }}\right)$, para todo $p$.

Passo 2. Usando a amostra em que $\left(y_{1}, y_{2}\right)$ é observado, estime a equação:

$$
y_{1 i r s p}=\boldsymbol{z}_{1 i r s p} \boldsymbol{\delta}+\boldsymbol{y}_{2 i r s p} \boldsymbol{\alpha}+\gamma \lambda_{i r s p}+\text { erro }_{i r s p}
$$

por dois estágios de mínimos quadrados usando como instrumentos $\left(z_{i r s p}, \lambda_{i r s p}\right)$.

Aplicamos este procedimento ao modelo que desejamos estimar. Devido ao uso de variáveis estimadas os desvios padrões estimados são inválidos [Pagan (1984)]. Para contornar este problema tivemos que usar a técnica de bootstraping. Na próxima seção os resultados são apresentados.

\subsection{Resultados ${ }^{14}$}

O primeiro resultado que apresentamos são os coeficientes estimados dos probits realizados no Passo 1 (Tabela 4.1), pois eles fornecem indícios interessantes acerca do que influencia a probabilidade da escolha do porto por onde a importação das UFs brasileiras realizam-se.

\footnotetext{
${ }^{14}$ Em todos os resultados apresentados nesta seção furtamo-nos a exibir aqueles ligados às dummies para o tipo de mercadoria importada por uma questão de conveniência, dado que se tratam de mais de noventa coeficientes, embora asseguramos que estas variáveis foram inseridas em todas as regressões.
} 
Tabela 4.1. - Modelos probit da probabilidade do porto ser utilizado

\begin{tabular}{|c|c|c|c|c|c|c|c|c|c|c|}
\hline Porto & Constante & $\begin{array}{c}L N(P I B \\
\text { Parceiro })\end{array}$ & $\begin{array}{c}\text { SQLN(PIB } \\
\text { Parceiro })\end{array}$ & $\begin{array}{l}L N(P O P \\
\text { Parceiro })\end{array}$ & $\begin{array}{c}\text { LN(ÁREA } \\
\text { Parceiro })\end{array}$ & $\begin{array}{c}L N(P I B \\
U F)\end{array}$ & $\begin{array}{c}S Q L N(P I B \\
U F)\end{array}$ & $\begin{array}{c}\text { LN(Distância ao } \\
\text { parceiro) }\end{array}$ & $\begin{array}{c}\text { LN(Distância } \\
\grave{a} U F)\end{array}$ & $\begin{array}{c}\text { SQLN(Distância } \\
\text { à UF) }\end{array}$ \\
\hline Itajaí & $15,6080^{*}$ & $0,4365^{* *}$ & $-0,0084^{* *}$ & $0,0789^{*}$ & $-0,0053$ & $-0,6959^{*}$ & $0,0206^{* *}$ & 0,01469 & $-5,9049^{*}$ & $0,4280^{*}$ \\
\hline Santos & $46,8850^{*}$ & $-0,6245^{*}$ & $0,0123^{*}$ & $-0,0966^{*}$ & $-0,0052$ & $-3,2663^{*}$ & $0,0938^{*}$ & $0,0650^{*}$ & $-3,1562^{*}$ & $0,2342^{*}$ \\
\hline Paranaguá & $25,2261^{*}$ & $0,8580^{*}$ & $-0,0169^{*}$ & $0,0750^{*}$ & 0,0050 & $-1,8557^{*}$ & $0,0496^{*}$ & $-0,0570^{* *}$ & $-6,2048^{*}$ & $0,4351^{*}$ \\
\hline Rio de Janeiro & $-52,3547^{*}$ & 0,1562 & $-0,0016$ & $-0,0413^{*}$ & $0,0311^{*}$ & $5,5607^{*}$ & $-0,1572^{*}$ & $0,1168^{*}$ & $0,0764^{* *}$ & $-0,0752^{*}$ \\
\hline Sepetiba & $-29,1236^{*}$ & $-0,5515^{* * *}$ & $0,0114^{* *}$ & $0,0919^{*}$ & $-0,0048$ & $4,2187^{*}$ & $-0,1180^{*}$ & $-0,3762^{*}$ & $-0,2199$ & $-0,0196$ \\
\hline Rio Grande & $79,9447^{*}$ & $-0,4062$ & 0,0062 & 0,0313 & $-0,0043$ & $-1,1863^{* *}$ & $0,0378^{* *}$ & $0,0860^{* *}$ & $-18,7244^{* *}$ & $1,2859^{*}$ \\
\hline Salvador & $88,8122^{*}$ & 0,5787 & $-0,0107$ & $0,1487^{*}$ & $-0,1390^{*}$ & $-10,2101^{*}$ & $0,2845^{*}$ & $-0,7793^{*}$ & $1,7340^{*}$ & $-0,2869^{*}$ \\
\hline S. F. do Sul & $58,8418^{*}$ & $-1,3414^{*}$ & $0,0235^{*}$ & $0,2437^{*}$ & $-0,0352^{* *}$ & $-6,2836^{*}$ & $0,1599^{*}$ & $0,1290^{*}$ & $5,9394^{*}$ & $-0,5681^{*}$ \\
\hline Vitória & $-5,3468$ & $1,6253^{*}$ & $-0,0299^{*}$ & $0,1024^{*}$ & $-0,0760^{*}$ & $-0,9737^{* *}$ & 0,0134 & $-0,3868^{*}$ & $0,9693^{*}$ & $-0,1902^{*}$ \\
\hline Aratu & $83,6351^{* *}$ & $-2,3148^{*}$ & $0,0404^{*}$ & 0,1852 & 0,0066 & $-6,5717$ & $0,1888^{* * *}$ & $-0,5575^{* *}$ & 0,7725 & $-0,1538$ \\
\hline Suape & $47,2681^{*}$ & 0,2209 & $-0,0036$ & 0,0101 & 0,0001 & $-5,5723^{*}$ & $0,1564^{*}$ & 0,0127 & $0,2678^{*}$ & $-0,1170^{*}$ \\
\hline Fortaleza & $69,4867^{*}$ & $-1,0183^{* *}$ & $0,0162^{* *}$ & $0,2197^{*}$ & $-0,0143$ & $-6,1766^{*}$ & $0,1728^{*}$ & $-0,1067$ & $0,4937^{*}$ & $-0,1483^{*}$ \\
\hline Belém & $-63,5817^{*}$ & $5,6654^{*}$ & $-0,1030^{*}$ & $0,3459^{*}$ & $-0,2274^{*}$ & $-2,4393^{*}$ & $0,0792^{*}$ & $-0,7442^{*}$ & $4,8186^{*}$ & $-0,5585^{*}$ \\
\hline
\end{tabular}

* significante a $1 \%$.

$* *$ significante a $5 \%$.

$* * *$ significante a $10 \%$.

Fonte: estimação própria. 
Ao analisar os coeficientes dos probits temos que ter em mente que eles não informam o impacto marginal de variações na variável explicativa sobre a probabilidade de uso do porto, apenas o sentido deste impacto. A probabilidade do porto de Itajaí ser utilizado aumenta conforme o PIB da UF importadora e do país exportador cresce; a distância em relação ao parceiro (país exportador) não afeta a probabilidade da escolha deste porto, mas o coeficiente da distância à UF é estatisticamente significante e negativo, indicando que quanto mais distante a UF de destino das importações menor a probabilidade de Itajaí ser utilizado. Este resultado pode ser explicado pelas informações levantadas no Capítulo 2 de que o porto de Itajaí, localizado em Santo Catarina, é utilizado principalmente pelas UFs na região Sul.

A probabilidade do porto de Santos ser utilizado na importação é menor quanto maior for o PIB da UF importadora e do país de origem das mercadorias importadas. O coeficiente da variável LN(Distância ao parceiro) é significante e tem sinal positivo, contrariando o resultado esperado. Já o coeficiente de $L N($ Distância à $U F)$ é significante e negativo.

A escolha do porto de Paranaguá como via de entrada é positivamente afetada pelo PIB do país exportador e negativamente afetada pelo PIB da UF importadora. As variáveis de distância em relação ao parceiro e à UF foram significantes e tiveram os sinais esperados, ou seja, negativos.

O coeficiente da variável $L N(P I B$ Parceiro) não é significante para o porto de Rio de Janeiro, enquanto que o coeficiente de $L N(P I B U F)$ é significante e positivo. As variáveis de distância em relação ao parceiro e à UF foram significantes, mas com sinais positivos. 
A escolha do porto de Sepetiba é negativamente afetada pelo PIB e distância do país de origem das importações. O PIB da UF de destino das importações afeta positivamente a probabilidade do uso de Sepetiba, enquanto que a distância da UF não foi estatisticamente significante.

Nenhuma das variáveis referentes ao país de origem dos bens importados foi estatisticamente significante para explicar a probabilidade do porto de Rio Grande ser usado, com exceção da distância que teve o sinal positivo. Quanto maior o PIB da UF de destino da importação menor é a probabilidade do porto de Rio Grande ser a via de entrada das mercadorias. No Capítulo 2, observamos que o Rio Grande do Sul é o principal usuário dos serviços do porto de Rio Grande; em conformidade com este dado, o coeficiente de LN(Distância à UF) é estatisticamente significante e negativo.

O PIB do parceiro não é estatisticamente significante para explicar o uso do porto de Salvador, mas a população é e tem sinal positivo. O PIB da UF de destino das importações foi estatisticamente significante e positivo. As variáveis de distância foram estatisticamente significantes para este porto, sendo que o aumento da distância ao parceiro reduz a probabilidade de Salvador ser o porto utilizado, enquanto que esta probabilidade é positivamente relacionada à distância em relação à UF. Mais uma vez, este resultado contraria a intuição e o resultado do Capítulo 2 de que o estado da Bahia é o principal usuário deste porto.

A escolha do porto de São Francisco do Sul é negativamente influenciada pelo PIB do parceiro e da UF. Os coeficientes das variáveis de distância são estatisticamente significantes, mas positivos. 
Quanto maior o PIB do país de origem das importações maior é a probabilidade do porto de Vitória ser utilizado para este comércio. Por outro lado, o PIB da UF de destino das importações afeta negativamente a escolha deste porto. A distância do porto de Vitória ao parceiro foi significante e teve sinal negativo como esperado, mas a distância do porto à UF, embora significante, exibiu sinal positivo.

A probabilidade do porto de Aratu ser utilizado é menor quando o PIB do país de origem das importações é maior e não é afetada pelo PIB da UF de destino das importações. O coeficiente da variável $L N($ Distância ao parceiro) é significante e negativo, indicando que a proximidade em relação à origem da importação é um fator que afeta positivamente a escolha deste porto. A variável $L N($ Distância à $U F)$ não foi estatisticamente significante.

Nenhuma das variáveis referentes ao país de origem das importações foi significante para explicar a probabilidade da escolha do porto de Suape. Quanto as variáveis relativas às UFs de destino da importação, o PIB da Uf tem efeito positivo sobre a probabilidade da escolha deste porto e a distância do porto à UF impacta positivamente a probabilidade de sua escolha.

O PIB do parceiro e da UF foram significantes e negativos na equação para probabilidade da escolha do porto de Fortaleza. A variável LN(Distância ao parceiro) não foi estatisticamente, mas $L N($ Distância à $U F)$ foi significante e positiva, mostrando que quanto maior a distância da UF ao porto de Fortaleza maior a probabilidade deste ser escolhido.

Por fim, os resultados para o porto de Belém indicam que a probabilidade deste porto ser escolhido para a realização de uma importação aumenta conforme o país de origem tem um 
PIB maior e cai conforme o PIB da UF de destino é maior. A distância ao país de origem afeta negativamente a probabilidade de escolha deste porto, enquanto que a distância à UF tem impacto positivo sobre a escolha.

Para tentar entender por que alguns dos coeficientes das variáveis de distância foram negativos temos que considerar as duas variáveis, distância ao parceiro e à UF, simultaneamente. Para tanto, construímos a Tabela 4.2, na qual apresentamos para cada porto se o sinal do coeficiente das variáveis $L N($ Distância à UF) e $L N($ Distância ao parceiro) for: estatisticamente significante e positivos $(+)$, estatisticamente significantes e negativos $(-)$ ou estatisticamente insignificantes (0).

Tabela 4.2. - Impacto das distâncias sobre a probabilidade de escolha dos portos

\begin{tabular}{lcc}
\hline Porto & Distância à UF & Distância ao Parceiro \\
\hline Itajaí & - & 0 \\
Santos & - & + \\
Paranaguá & - & - \\
Rio de Janeiro & + & + \\
Sepetiba & - & - \\
Rio Grande & - & + \\
Salvador & + & - \\
S. F. do Sul & + & + \\
Vitória & + & - \\
Aratu & 0 & - \\
Suape & + & 0 \\
Fortaleza & + & - \\
Belém & + & - \\
\hline
\end{tabular}

Fonte: Construída com base na tabela 4.1.

Considere o caso dos portos de Santos e Rio Grande; para estes portos, a distância à UF e ao parceiro impactam, nesta ordem, negativamente e positivamente a probabilidade de serem escolhidos. A opção das UFs em usar estes portos, apesar de serem mais distantes do país de 
origem das importações, é justificada, pois o menor custo de transportar as mercadorias do porto à UF em função da proximidade entre eles, em média, compensa o gasto adicional com transporte marítimo. A probabilidade da escolha do porto de Itajaí também cresce quando a distância de Itajaí à UF de destino das importações é menor, embora esta probabilidade não seja afetada pela distância ao parceiro. Logo, estes três portos formam um grupo para o qual sua utilização é orientada pela proximidade ao destino das importações.

Na situação inversa estão os portos de Salvador, Vitória, Fortaleza e Belém cuja probabilidade de serem escolhidos diminui com a proximidade em relação ao estado de destino da importação, mas aumenta com a proximidade ao país de origem. No caso destes portos, as UFs preferem utilizá-los mesmo sendo mais distantes em relação a elas pois são mais próximos do país de origem e, em média, a queda do custo com o transporte deste ao porto compensa o aumento do custo de transporte os bens do porto à UF referente ao uso de um porto mais distante. A probabilidade de escolha do porto de Aratu independe da distância à UF, mas é negativamente afetada pela distância em relação ao país de origem das importações. Então, Salvador, Vitória, Aratu, Fortaleza e Belém compõem um grupo de portos cuja escolha é orientada pela proximidade ao parceiro comercial.

A probabilidade da escolha de Paranaguá e Sepetiba é negativamente afetada por ambas as distâncias. No outro extremo, temos os portos de Rio de Janeiro, São Francisco do Sul e Suape cuja probabilidade de escolha é positivamente afetada pelas duas distância.

A partir dos probits, obtivemos as razões inversas de Mills (IMR) a as inserimos na estimação da equação (4.5) como sugerido por Wooldridge (2002). Os resultados estão na Tabela 4.3, nela incluímos também estimações sem o uso do estimador de Heckman (modelo 1) para 
mostrar o efeito do viés de seleção. Comparando os dois modelos, vemos que os coeficientes das variáveis de controle para o frete marítimo são significantes, têm o sinal esperado e não sofrem grandes alterações quando introduzimos o estimador de Heckman. 
Tabela 4.3. - Resultados: medidas de eficiência portuária relativa

(P-valor entre parênteses), continua

\begin{tabular}{|c|c|c|}
\hline Variável & Modelo (1) & Modelo (2) \\
\hline \multirow[t]{2}{*}{ Lnkg } & $0,7602^{*}$ & $0,8824^{*}$ \\
\hline & $(0,0000)$ & $(0,0000)$ \\
\hline \multirow[t]{2}{*}{ Lnvolume } & $-0,2725^{*}$ & $-0,3239^{* *}$ \\
\hline & $(0,0000)$ & $(0,0384)$ \\
\hline \multirow[t]{2}{*}{ Sqlnvolume } & 0,0092 & $0,0104^{*}$ \\
\hline & $(0,0000)$ & $(0,0332)$ \\
\hline \multirow[t]{2}{*}{ Lnvalor/peso } & $0,5075^{*}$ & $0,6830^{*}$ \\
\hline & $(0,0000)$ & $(0,0000)$ \\
\hline \multirow[t]{2}{*}{ Lndist_parceiro } & $0,3422^{*}$ & $0,3242^{*}$ \\
\hline & $(0,0000)$ & $(0,0000)$ \\
\hline \multirow[t]{2}{*}{ Lndist_uf } & $0,1528^{*}$ & $0,0983^{* *}$ \\
\hline & $(0,0000)$ & $(0,0101)$ \\
\hline \multirow[t]{2}{*}{ Sqlndist_uf } & $-0,0222^{*}$ & $-0,0150^{*}$ \\
\hline & $(0,0000)$ & $(0,0070)$ \\
\hline \multirow[t]{2}{*}{ Itajaí } & $-0,0438$ & 0,0457 \\
\hline & $(0,3160)$ & $(0,4707)$ \\
\hline \multirow[t]{2}{*}{ Paranaguá } & $-0,0851^{*}$ & 0,0354 \\
\hline & $(0,0010)$ & $(0,2591)$ \\
\hline \multirow{2}{*}{ Rio de Janeiro } & $-0,0364$ & 0,0619 \\
\hline & $(0,2060)$ & $(0,1464)$ \\
\hline \multirow[t]{2}{*}{ Sepetiba } & $-0,1274^{*}$ & $-0,0257$ \\
\hline & $(0,0030)$ & $(0,5303)$ \\
\hline \multirow[t]{2}{*}{ Rio Grande } & 0,0055 & $-0,0069$ \\
\hline & $(0,7170)$ & $(0,8192)$ \\
\hline \multirow[t]{2}{*}{ Salvador } & $0,0825^{*}$ & 0,0514 \\
\hline & $(0,0010)$ & $(0,4458)$ \\
\hline \multirow[t]{2}{*}{ São Francisco do Sul } & $-0,1447^{*}$ & $-0,0516$ \\
\hline & $(0,0000)$ & $(0,2995)$ \\
\hline \multirow[t]{2}{*}{ Vitória } & 0,0214 & 0,0274 \\
\hline & $(0,2820)$ & $(0,2762)$ \\
\hline \multirow[t]{2}{*}{ Aratu } & $0,6739^{*}$ & $0,4454^{*}$ \\
\hline & $(0,0000)$ & $(0,0002)$ \\
\hline \multirow[t]{2}{*}{ Suape } & $-0,0496$ & $-0,0397$ \\
\hline & $(0,2340)$ & $(0,5593)$ \\
\hline \multirow[t]{2}{*}{ Fortaleza } & $0,1164^{*}$ & 0,0805 \\
\hline & $(0,0000)$ & $(0,1638)$ \\
\hline \multirow[t]{2}{*}{ Belém } & $-0,2790^{*}$ & $-0,3912^{*}$ \\
\hline & $(0,0010)$ & $(0,0009)$ \\
\hline \multicolumn{3}{|c|}{ Estimação por variáveis instrumentais, sem o estimador de Heckman. } \\
\hline \multirow{2}{*}{\multicolumn{3}{|c|}{ * Estimação por variáveis instrumentais, com o estimador de Heckman. }} \\
\hline & & \\
\hline \multicolumn{3}{|l|}{ ** significante a $5 \%$} \\
\hline \multicolumn{3}{|l|}{$* * *$ significante a $10 \%$} \\
\hline
\end{tabular}


Tabela 4.3. - Resultados: medidas de eficiência portuária relativa

(P-valor entre parênteses), final

\begin{tabular}{|c|c|c|}
\hline Variável & Modelo (1) & Modelo (2) \\
\hline IMR Itajaí & - & $\begin{array}{l}-0,0436^{*} \\
(0,0003)\end{array}$ \\
\hline & - & $0,0349^{* * *}$ \\
\hline IMR Santos & & $(0,0517)$ \\
\hline & - & $0,0363^{*}$ \\
\hline IMR Paranaguá & & $(0,0090)$ \\
\hline & - & $-0,0266$ \\
\hline IMR Rio de Janeiro & & $(0,5381)$ \\
\hline IMR Sepetiba & - & $\begin{array}{c}0,1697^{*} \\
(0,0081)\end{array}$ \\
\hline & - & $-0,0270^{* * * *}$ \\
\hline IMR Rio Grande & & $(0,0694)$ \\
\hline IMR Salvador & - & $\begin{array}{c}0,1460^{* * *} \\
(0,0699)\end{array}$ \\
\hline & - & 0,0014 \\
\hline IMR São Francisco do Sul & - & $\begin{array}{c}(0,9439) \\
-0,0594^{* * *}\end{array}$ \\
\hline IMR Vitória & & $(0,0632)$ \\
\hline IMR Aratu & - & $\begin{array}{c}-0,1359^{* * * *} \\
(0,0898) \\
-0,0413\end{array}$ \\
\hline IMR Suape & & $(0,1561)$ \\
\hline IMR Fortaleza & - & $\begin{array}{l}0,0313^{* * *} \\
(0,0612) \\
-0,0755^{*}\end{array}$ \\
\hline IMR Belém & & $(0,0000)$ \\
\hline \multicolumn{3}{|c|}{$\begin{array}{l}\text { Estimação por variáveis instrumentais, sem o estimador de Heckman. } \\
\text { * Estimação por variáveis instrumentais, com o estimador de Heckman. } \\
\text { * significante a } 1 \% \text {. } \\
\text { ** significante a } 5 \% . \\
\text { *** significante a } 10 \% \text {. } \\
\text { Fonte: estimação própria. }\end{array}$} \\
\hline
\end{tabular}


Tomando o modelo 2 como referência tecemos as seguintes considerações. Como era de se esperar, o custo do frete marítimo aumenta quando o peso transportado é maior. Cada 1\% de aumento na quantidade transportada, medida em kg, provoca um aumento no frete de 0,88\%. O coeficiente negativo da variável Lnvolume, i.e. o volume total de mercadorias transportadas entre o porto de desembarque no Brasil e o país de origem das importações, suporta a hipótese de economias de escala no transporte marítimo. O incremento do fluxo de mercadorias de um país estrangeiro para um dos portos da amostra pode elevar o frete marítimo devido à deseconomias de congestionamento, como é indicado pelo coeficiente positivo da variável Sqlnvolume $e^{15}$

O volume considerado é unilateral, ou seja, somente no sentido do país estrangeiro para o porto no Brasil. O custo do transporte marítimo geralmente eleva-se se há um desequilíbrio no fluxo em uma rota, por exemplo, se mais mercadorias chegam a um porto $p$ vindas de um país $s$ do que são exportadas através de $p$ para $s$, porque isto implica que os navios terão que operar relativamente mais vazios em um dos sentidos. Um elevado volume em um sentido apenas, como o estamos medindo, pode afetar positivamente o custo com frete marítimo porque implicitamente significa que há a possibilidade de desequilíbrio no fluxo em uma rota. Esta é outra razão, além de deseconomias de congestionamento, para o sinal negativo de Sqlnvolume.

O custo de transporte marítimo também cresce com a distância em relação ao parceiro, como era de se esperar, já que um dos principais componentes do custo variável desta atividade, o gasto com combustíveis, aumenta com a distância a ser percorrida. Se um estado $r$ importando

\footnotetext{
${ }^{15}$ A importância econômica deste resultado pode ser vista a partir do trabalho de Behrens et al (2006) o qual constrói um modelo teórico para mostrar como a geografia econômica interna de dois países é relacionada devido ao que os autores denominam (des)economias de densidade, isto é, (aumento) redução no custo de transporte provocada pelo aumento do volume transportado.
} 
uma mercadoria $i$ de um país $s$ através do porto $p$ decidir passar a comprá-la de um país $s^{\prime}$ localizado a uma distância $1 \%$ menor do que o país $s$ do porto $p$, o custo com transporte marítimo cai aproximadamente 0,32\%. Um componente importante do frete marítimo é o seguro; mercadorias com maior valor unitário, em geral, estão sujeitas à cobrança de um seguro mais elevado. A variável Lnvalor/peso, a razão entre o valor FOB (US\$) e o peso (kg) de fluxo de importação, captura este componente do frete marítimo. O sinal positivo e significante de Lnvalor/peso reflete a correlação positiva entre seguro e valor unitário da mercadoria.

As variáveis Lndist_uf e Sqlndist_uf representam, respectivamente, o logaritmo natural da distância em relação ao estado de destino das mercadorias e seu quadrado. A lógica para a adição destas variáveis é de que a proximidade em relação ao porto de desembarque traz vantagens ao importador tais como contato face-a-face ou experiência que agilizam e barateiam o desembaraço dos bens. Por outro lado, a proximidade excessiva pode ter efeito negativo sobre o custo de transporte, pois implica em preferência em relação ao uso de determinados portos ou rigidez para alterar o porto de desembarque. Para captar esta relação possivelmente não linear incluímos não só Lndist_uf como também seu quadrado, Sqlndist_uf. Os coeficientes estimados para Lndist_uf e Sqlndist_uf significantes e, respectivamente, positivo e negativo confirmam a possibilidade da existência desta relação não linear.

Finalmente, chegamos ao objeto deste estudo, a contribuição dos portos ao custo de transporte associado às importações brasileiras e a comparação de sua eficiência relativa. Isto é feito através da análise dos coeficientes das dummies que indicam qual porto foi utilizado. Como indicado acima, optamos por omitir o coeficiente da dummy referente ao porto de Santos. O coeficiente da dummy para um porto $p$ deve ser interpretado como a variação percentual, 
dividida por 100, que o custo de transporte referente à importação do bem $i$ pelo estado $r$ proveniente do país $s$ sofreria se o porto de desembarque fosse $p$ e não Santos ${ }^{16}$.

Observamos que apenas dois coeficientes são estatisticamente significantes: aqueles referentes aos portos de Aratu e Belém. No caso do primeiro, os resultados mostram que ele é relativamente menos eficiente do que Santos. Se certa mercadoria $i$, oriunda do país $s$ e destinada à UF $r$ utilizar o porto de Aratu ao invés do porto de Santos, o custo de transporte cresce aproximadamente 44,5\%, somente devido à mudança de porto. O segundo, Belém, mostrou-se mais eficiente em relação ao porto de Santos. O custo de transporte associado à importação de uma dada mercadoria sofre uma redução de quase $40 \%$ quando Belém é o porto de entrada ao invés de Santos.

Na Tabela 4.3, também podem ser vistos os coeficientes das razões inversas de Mills de cada porto incluídas na estimação com o intuito de corrigir o problema de viés de seleção da amostra. Observe que apenas dois dos treze coeficientes não são estatisticamente significantes, o que é um indício de viés de seleção. Esta noção é aprofundada quando comparamos os coeficientes das dummies para os portos no modelo sem correção (Modelo 1) e com correção (Modelo 2) para viés de seleção. No Modelo 1, sete das doze dummies portuárias são estatisticamente significantes, sendo que quatro mostraram sinal negativo, ou seja, os portos são relativamente mais eficientes do que Santos (Paranaguá, Sepetiba, São Francisco do Sul e Belém); e três apresentaram coeficientes positivos, a saber, Salvador, Aratu e Fortaleza.

\footnotetext{
${ }^{16} \mathrm{O}$ exponencial das dummies para os portos menos um é a expressão matemática precisa da variação percentual no custo de transporte decorrente da mudança do porto de entrada. A interpretação sugerida no texto é uma aproximação.
} 
Após realizar a correção para o viés de seleção da amostra, notamos que nenhum dos coeficientes dos portos que não eram estatisticamente significantes (Itajaí, Rio de Janeiro, Rio Grande, Vitória e Suape) passou a ser significante. Por outro lado, os portos de Paranaguá, Sepetiba, São Francisco do Sul deixaram de ser mais eficientes em relação a Santos, enquanto que Salvador e Fortaleza deixaram de ser menos eficientes em relação a Santos.

No caso dos portos de Paranaguá, Sepetiba e São Francisco do Sul, a ausência na amostra das informações sobre o custo de transporte para realizar importações através destes portos quando este custo é relativamente mais elevado induz o resultado de que eles seriam mais eficientes quando comparados ao porto de Santos. O inverso ocorre com Salvador e Fortaleza, a falta de observações referentes ao custo de importar mercadoria por Santos faz este parecer relativamente mais eficiente do que aquele. Feitas as devidas correções, os resultados permitem concluir que, aparte as exceções já assinaladas, os portos podem ser considerados neste estudo não apresentaram diferenciais de eficiência relevantes em 2002. 


\section{Conclusões}

O comércio internacional brasileiro depende fundamentalmente dos portos. A via marítima é a principal via de transporte das exportações e importações do país. No entanto, o sistema portuário do Brasil exibe um atraso em relação aos outros países do mundo, especialmente em relação a outros países em desenvolvimento como Coréia do Sul, México e Argentina. Isto afeta a competitividade das empresas instaladas no Brasil e causa perdas à economia.

O marco regulatório do setor portuário vem sendo modificado de forma a aumentar a eficiência do setor e superar esta restrição ao crescimento da economia. Destacamos três momentos da reforma do setor portuário: 1) a extinção da Portobrás, que desde 1975 administrava os portos brasileiros diretamente ou indiretamente através de companhias subsidiárias ou concessões estaduais e privadas; 2) a promulgação da Lei 8.630/93, conhecida como “Lei de Modernização dos Portos”. que visa promover a descentralização do setor, permitir a entrada de recursos privados, estimular investimentos no setor, promover a concorrência e adequar o quantitativo da mão-de-obra aos novos padrões tecnológicos, entre outros; e 3) a criação do GEMPO - Grupo Executivo para Modernização dos Portos - com a finalidade de acelerar a implementação da Lei 8.630/93.

Na busca por aumentar a eficiência do setor portuário, é importante que a agência reguladora disponha de medidas para monitorar os portos, isto é, ela deve dispor de meios de avaliar o desempenho dos portos. Há uma literatura crescente preocupada em atender esta demanda. Alguns trabalhos, como Estache et al (2002), Cullinane et al (2003) e Barros (2005), utilizam a metodologia de fronteira estocástica que os permite comparar a performance dos portos com padrões técnicos ou comportamentais. Esta metodologia tem algumas deficiências, mais 
especificamente, a necessidade de um volume grande de dados de acesso difícil e problemas de definições dos insumos e produtos das atividades portuárias.

Outros trabalhos procuram medidas de eficiência relativa dos portos, ou seja, obter medidas dos custos dos portos e as comparar para, desta forma, poder ordená-los. Os trabalhos utilizando DEA fazem parte desta literatura, porém eles ainda possuem a desvantagem da literatura de fronteira estocástica de necessitar de um volume elevado de dados de acesso difícil. Uma segunda abordagem, dentro deste grupo de trabalhos que procura superar esta desvantagem foi apresentada por Blonigen \& Wilson (2006), ${ }^{17}$ consiste em separar através de uma regressão econométrica a variação dos custos de comércio internacional em seus componentes devida ao porto de origem, frete marítimo e porto de destino.

Neste trabalho, desenvolvemos a metodologia de Blonigen \& Wilson (2006), corrigindo-a em dois pontos em que a metodologia original apresentava falhas seguindo os procedimentos descritos por Wooldridge (2002) para estimar modelos deste tipo. A primeira destas falhas foi não considerar que algumas das variáveis explicativas, como a quantidade e volume transportados, dependem da variável dependente, o custo de transporte, ou seja, que algumas variáveis são endógenas. Corrigimos este problema introduzindo instrumentos para as variáveis endógenas; os instrumentos utilizados são variáveis que fariam parte de um modelo gravitacional de comércio.

A segunda falha diz respeito ao viés de seleção que a amostra possui, já que há somente informação sobre comércio através de um porto quando isto é observado, o que ocorre apenas quando o custo de importar através deste porto é menor do que certo nível. Introduzimos o

${ }^{17}$ O volume de dados na abordagem de Blonigen \& Wilson (2006) também é elevado, mas o acesso às informações necessárias é mais fácil, pois se tratam de dados de comércio internacional que os países geralmente compilam e disponibilizam. 
estimador de Heckman [Heckman (1979)] para lidar com este problema. O estimador de Heckman requer que utilizemos um modelo probit para estimar a probabilidade de um porto ser utilizado para certo comércio. Os probits estimados por si só são interessantes na medida em que nos revelam alguns dos fatores determinantes da escolha dos portos.

Em particular, destacamos a importância da distância em relação à UF de destino e ao país de origem das importações como variáveis explicativas da probabilidade de escolha do porto. Vimos que a opção por alguns portos dá-se em função de sua proximidade à UF de destino das importações, mesmo que isto acarrete ganho de custo em função do aumento da distância entre o país de origem dos bens importados e o porto escolhido. Neste grupo de portos vimos que figuram Santos, Rio Grande e Itajaí.

Identificamos também um segundo grupo de portos cuja opção por seu uso está ligada a sua proximidade em relação ao país de origem dos bens importados, mesmo quando isto aumenta os custos com o transporte do porto à UF onde ocorre o consumo final. Nesse grupo de portos encaixaram-se Salvador, Vitória, Aratu, Fortaleza e Belém.

Aplicamos a metodologia melhorada para as importações brasileiras que são realizadas por um conjunto de treze portos e, através dela, obtivemos estimativas da variação do custo de importação decorrente da mudança do porto de desembarque. Notamos que os portos estudados não diferem quanto a sua eficiência, com exceção dos portos de Aratu e Belém, respectivamente menos e mais eficiente do que Santos. Uma das descobertas importantes é que este resultado só é obtido quando levamos em consideração o viés de seleção da amostra, isto é, a falta de observações referentes aos custos de realizar certa importação por todos os portos devida ao não uso de alguns dos portos para o comércio considerado. 
Os resultados permitem ainda analisar as características do transporte marítimo, ao menos daquele que realiza as importações brasileiras. Como esperávamos, o frete marítimo é positivamente correlacionado à quantidade transportada, ao valor do seguro - aproximado pela razão valor da carga/peso da carga - e à distância em relação ao parceiro comercial.

Chamamos a atenção para a existência de economias de escala no transporte marítimo, isto é, a queda no custo decorrente do aumento do volume total transportado entre um porto e um país. Notamos também que as economias de escala podem vir a se tornar deseconomias de escala devido a congestionamento ou desequilíbrio no comércio. Observamos que os importadores mais próximos dos portos têm vantagens na negociação do frete marítimo, conseguindo uma tarifa menor. Porém, o excesso de proximidade reduz o poder de barganha e pode aumentar o custo de transporte marítimo.

Além do interesse nos resultados, o aprimoramento da metodologia é uma contribuição deste trabalho, como os próprios resultados mostraram. Esta metodologia poderia ser replicada para uma amostra maior de portos e para vários anos de informação de modo a traçar a evolução da eficiência relativa permitindo o monitoramento dos portos ou avaliar o impacto de políticas voltadas ao aumento da eficiência portuária.

Isto é de particular interesse da recém criada Secretária Especial de Portos, vinculada diretamente ao Presidente, que tem como uma de suas atribuições “promover a execução e a avaliação de medidas, programas e projetos de apoio ao desenvolvimento da infra-estrutura portuária marítima e dos portos outorgados às companhias docas”18. Este trabalho indica

\footnotetext{
${ }^{18}$ Medida provisória no. 369, de 7 de maio de 2007.
} 
ainda a linha que os projetos da referida Secretaria deve seguir. O resultado encontrado de que os portos na amostra não apresentam diferenças de eficiência e as evidências citadas no texto que apontam que os portos brasileiros são menos eficientes quando comparados a portos estrangeiros sugeri que a questão da eficiência portuária no Brasil não deve ser pensada individualmente para cada porto, mas há um problema comum a todos eles. Em outras palavras, é um problema do setor, requerendo, portanto, uma política nacional setorial. 


\section{Bibliografia}

Barros, C. P. "Decomposing Growth in Portuguese Seaports: A Frontier Cost Approach". Maritime Economics \& Logistics. 7, p. 297-315. 2005.

Behrens, K., C. Gaigné, Ottaviano I. P., J. Thisse. "How density economies in international transportation link the internal geography of trading partners”. Journal of Urban Economics. Vol. 60, p. 248-263, 2006.

Blonigen, B. A., W. W. Wilson. "New measures of port efficiency using international trade data”. NBER Working Paper Series, n. 12052, 2006.

BNDES. Cadernos de Infra-Estrutura: Arrendamentos portuários. Março, 2001.

Campos Neto, C. A. S. "Portos Brasileiros: área de influência, ranking, porte e principais produtos movimentados”. Texto para Discussão n. 1164, IPEA, fevereiro, 2006.

Clark, X., D. Dollar, A. Micco. "Port efficiency, maritime transport costs, and bilateral trade". Journal of Development Economics. Vol. 75, p. 417-450. 2004.

Cullinane, K. P. B., D. W. Song. “A Stochastic Frontier Model of the Productive Efficiency of Korean Container Terminals”. Applied Economics. Vol. 35, p. 251-267, 2003

Emrouznejad, A. "Data Envelopment Analysis Home Page”, http://www.DEAzone.com, last viewed 6/13/2007.

Estache, A., M. González, L. Trujillo. "Efficiency Gains from Port Reform and the Potential for Yardstick Competition: Lessons from Mexico”. World Development, Vol. 30, No. 4, p. 545-560. 2002.

Evenett, S. J., W. Keller. "On theories explaining the success of the gravity equation”. NBER Working Paper Series, n. 6529, april, 1998.

Frink, C., A. Mattoo, I. C. Neagu. "Trade in international maritime service: how much does policy matter?”. The World Bank Economic Review. Vol. 16, n. 1, p. 81-108, 2002.

Global Competitiveness Report 2006-2007. Palgrave, Macmillan, 2006.

González. M. M., L. Trujillo. "Efficiency Measurement in the Port Industry: A Survey of the Empirical Evidence”. Mimeo. 2007.

Heckman, J. "Sample Selection Bias as a Specification Error”. Econometrica, 47, p. 153-161. 1979.

Hummels, D. “Time as a trade barrier”. Working paper. 2001. (disponível em http://www.mgmt.purdue.edu/faculty/hummelsd/research.htm)

Kumbhakar, S. C., C. A. Knox Lovell. Stochastic Frontier Analysis. Cambridge University Press, 2000. 
Leamer, E., J. Levinsohn. “International trade theory: the evidence”, inG. M. Grossman e K. Rogoff (eds.), Handbook of International Economics, vol. 3, Elsevier, Amsterdam.

Pagan, A. "Econometric Issues in the Analysis of Regressions with Generated Regressors". International Economic Review, 25(1), 221-47. 1984.

Redding, S., e A. J. Venables. "Economic geography and international inequality". CEP Discussion Paper, 495, London School of Economics. 2001.

Tongzon, J. "Efficiency measurement of selected Australian and other international ports using data envelopment analysis”. Transportation Research Part A. 35, p. 107-122. 2001.

Vieira, G. B. B. Transporte Internacional de Cargas. São Paulo: Aduaneiras. 2003.

Wooldridge, J. M. Econometric Analysis of Cross Section and Panel Data. Cambridge, Massachusetts: MIT Press, 2002. 


\section{APÊNDICE A.1}

Quadro A.1 - Linhas de Desejo/Portos

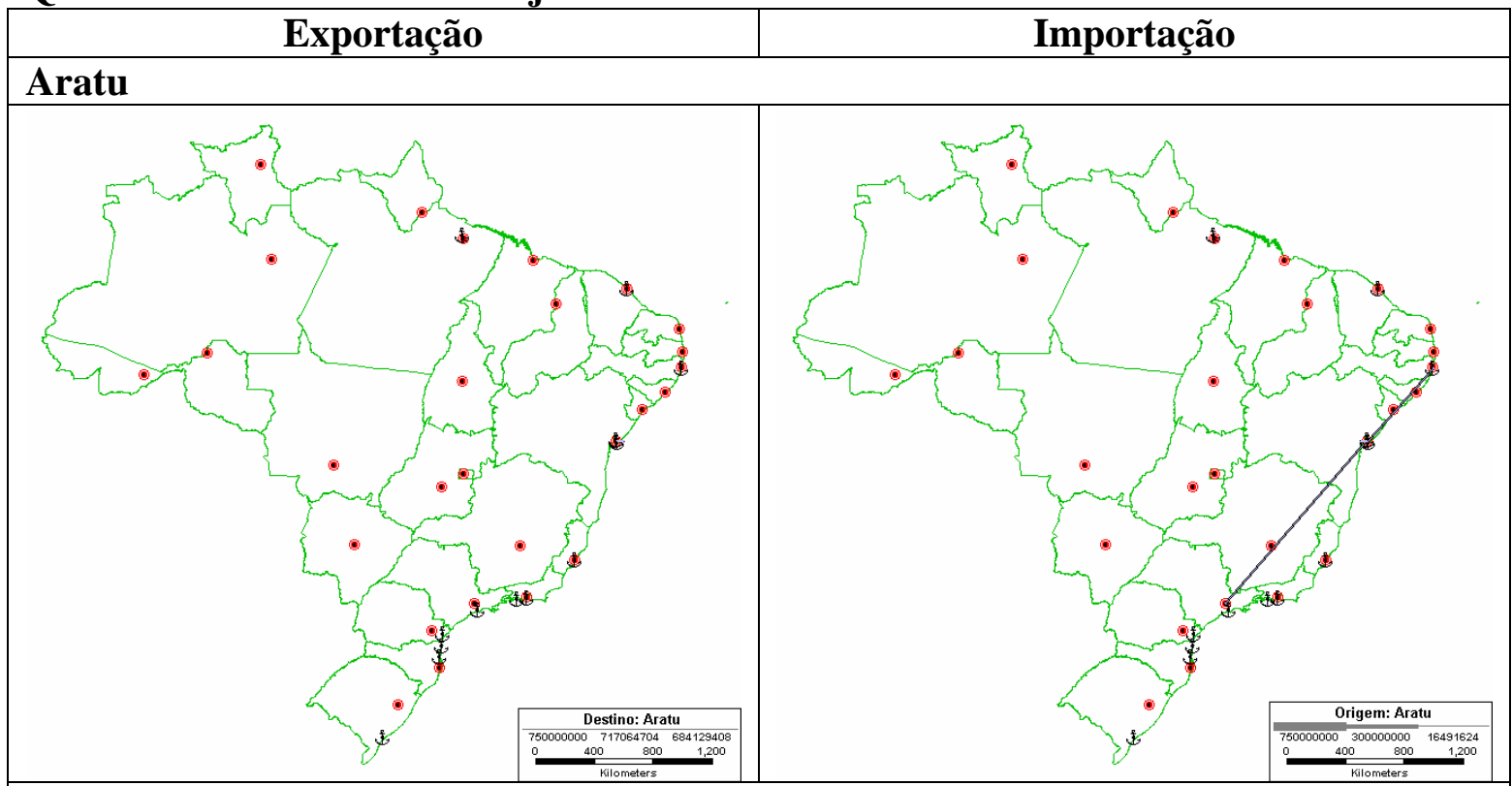

\section{Belém}
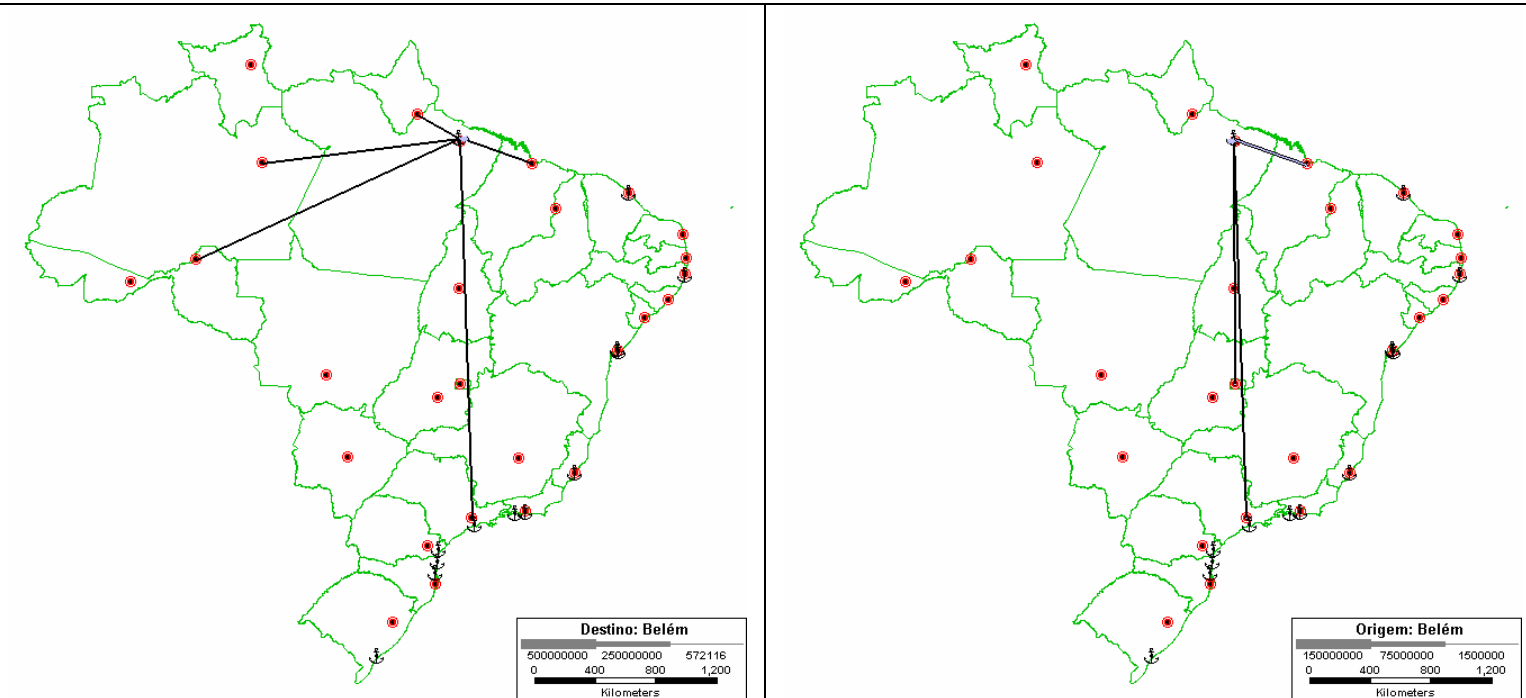

Fonte: MDIC, Aliceweb. 
Quadro A.1 - Linhas de Desejo/Portos

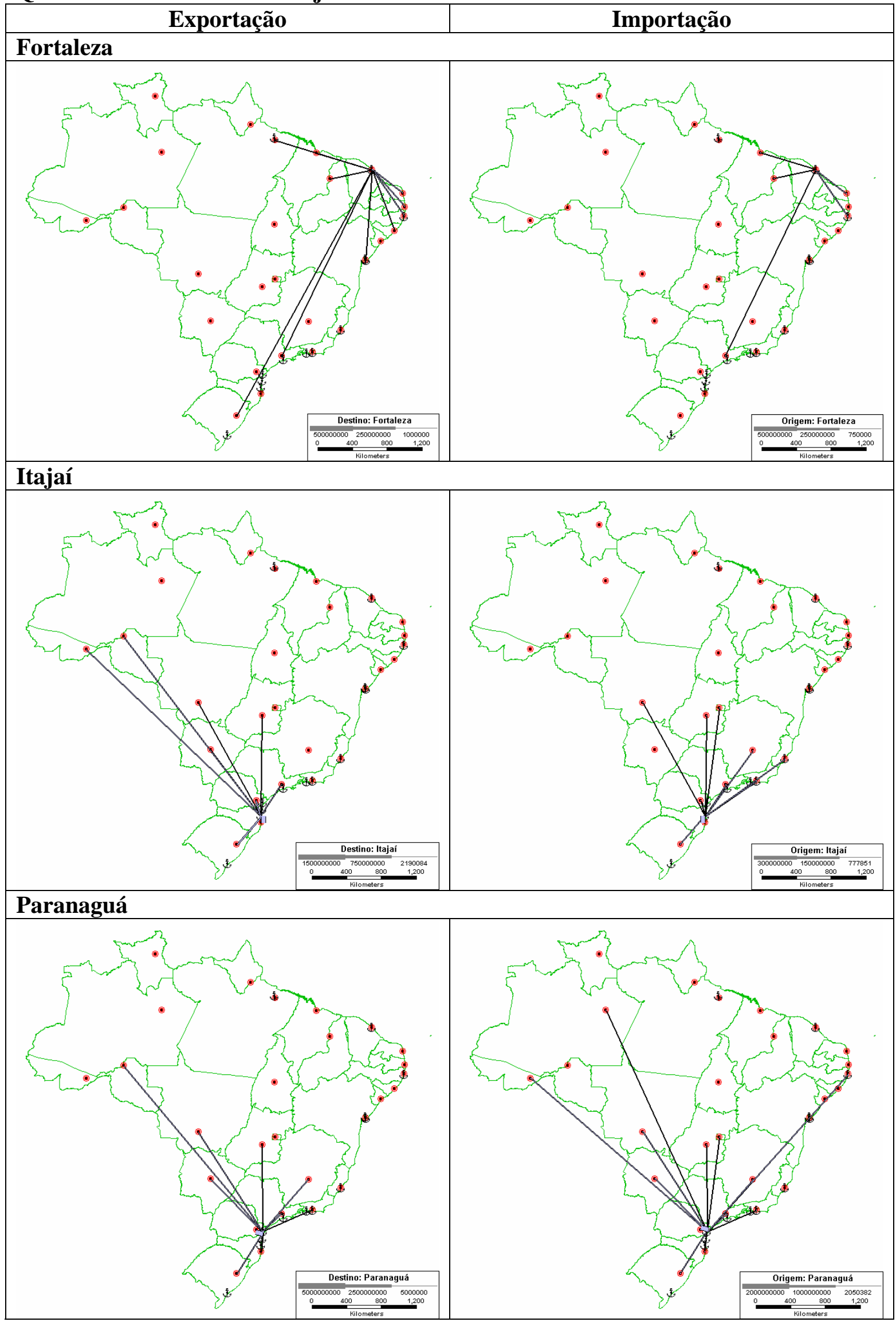

Fonte: MDIC, Aliceweb. 
Quadro A.1 - Linhas de Desejo/Portos

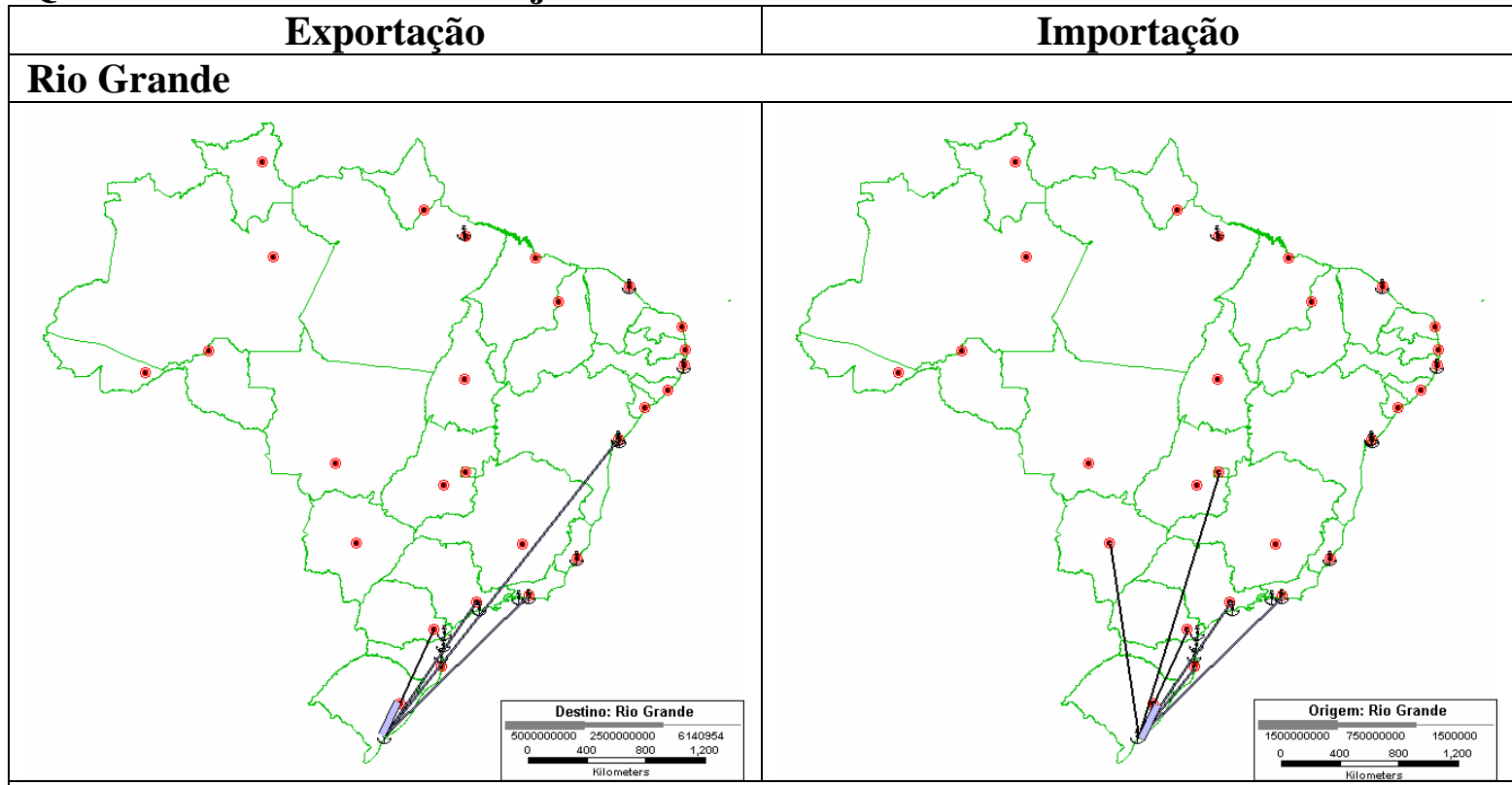

\section{Rio de Janeiro}

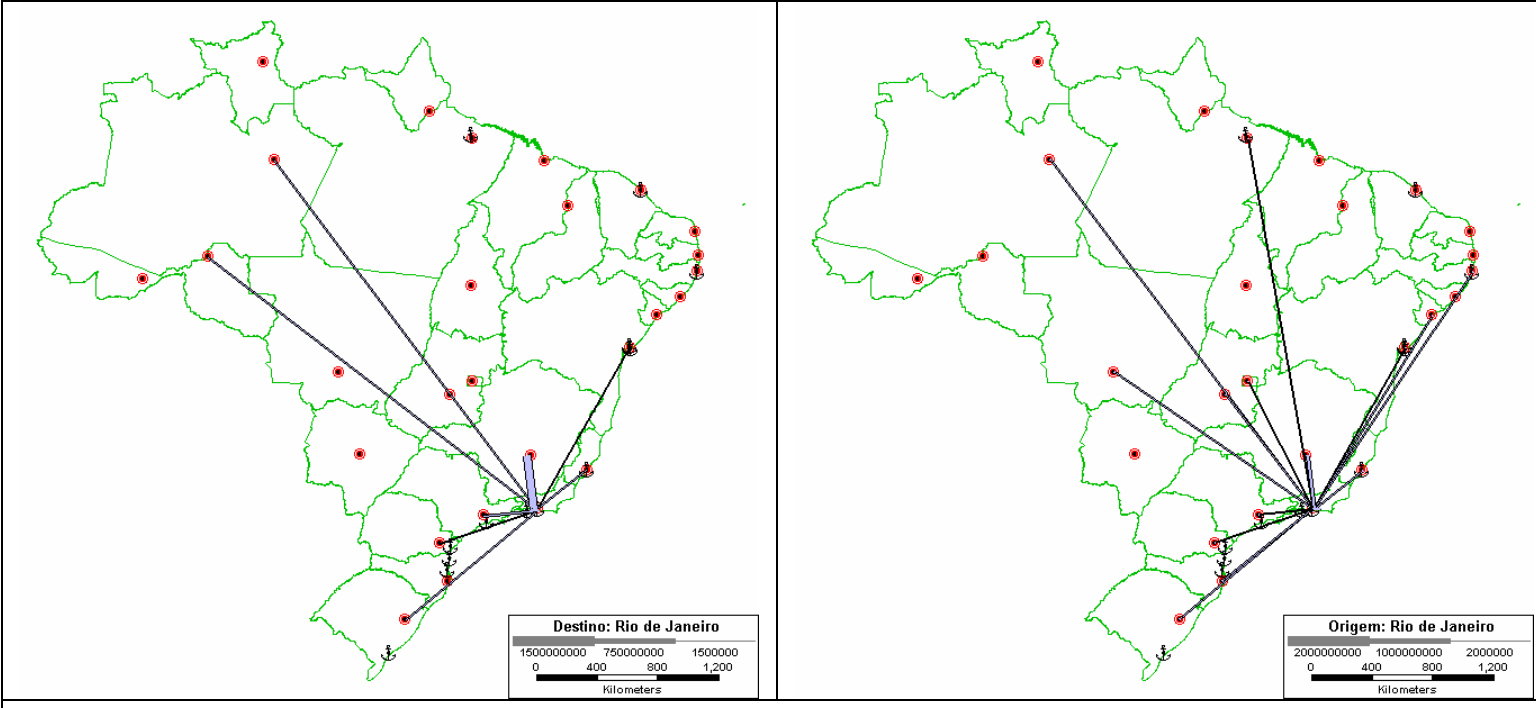

Salvador
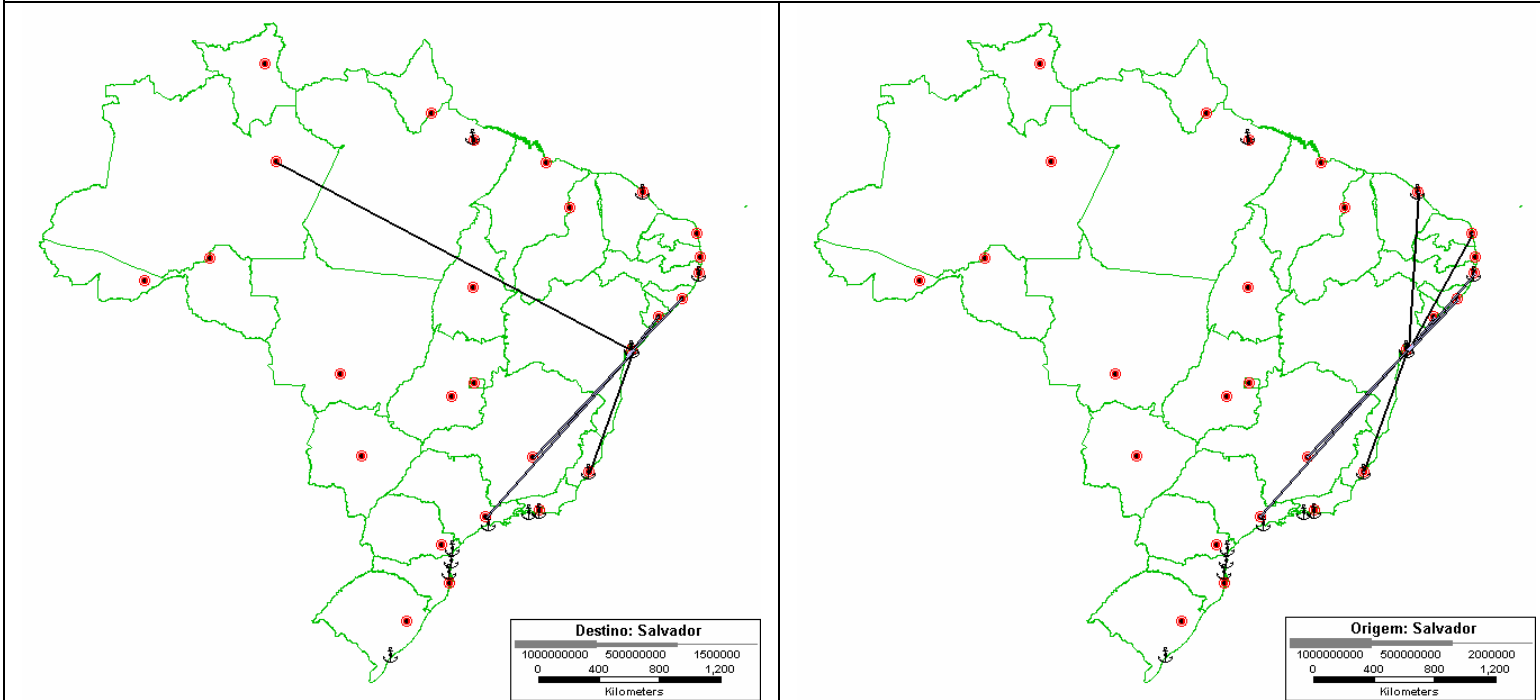

Fonte: MDIC, Aliceweb. 
Quadro A.1 - Linhas de Desejo/Portos

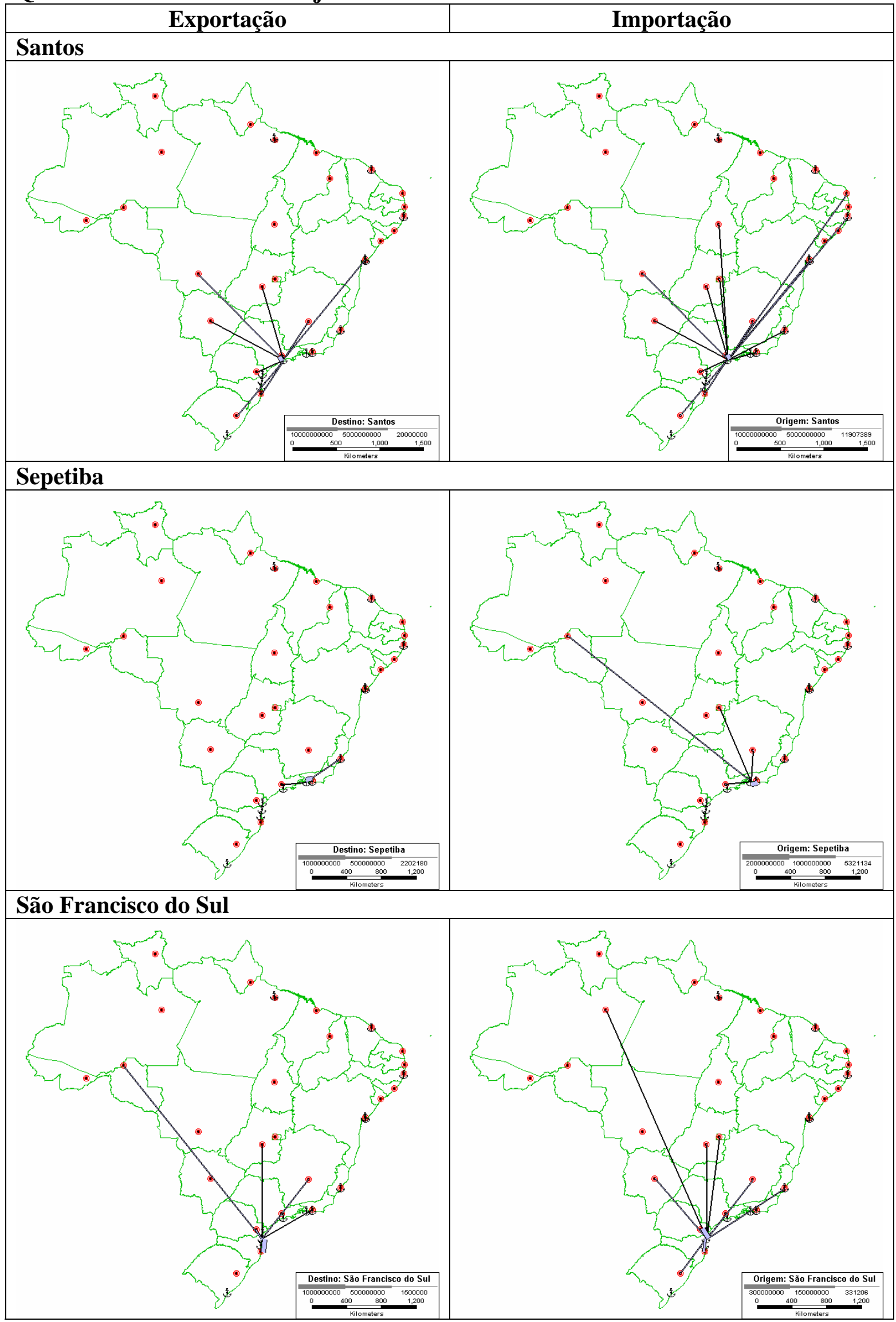

Fonte: MDIC, Aliceweb. 
Quadro A.1 - Linhas de Desejo/Portos

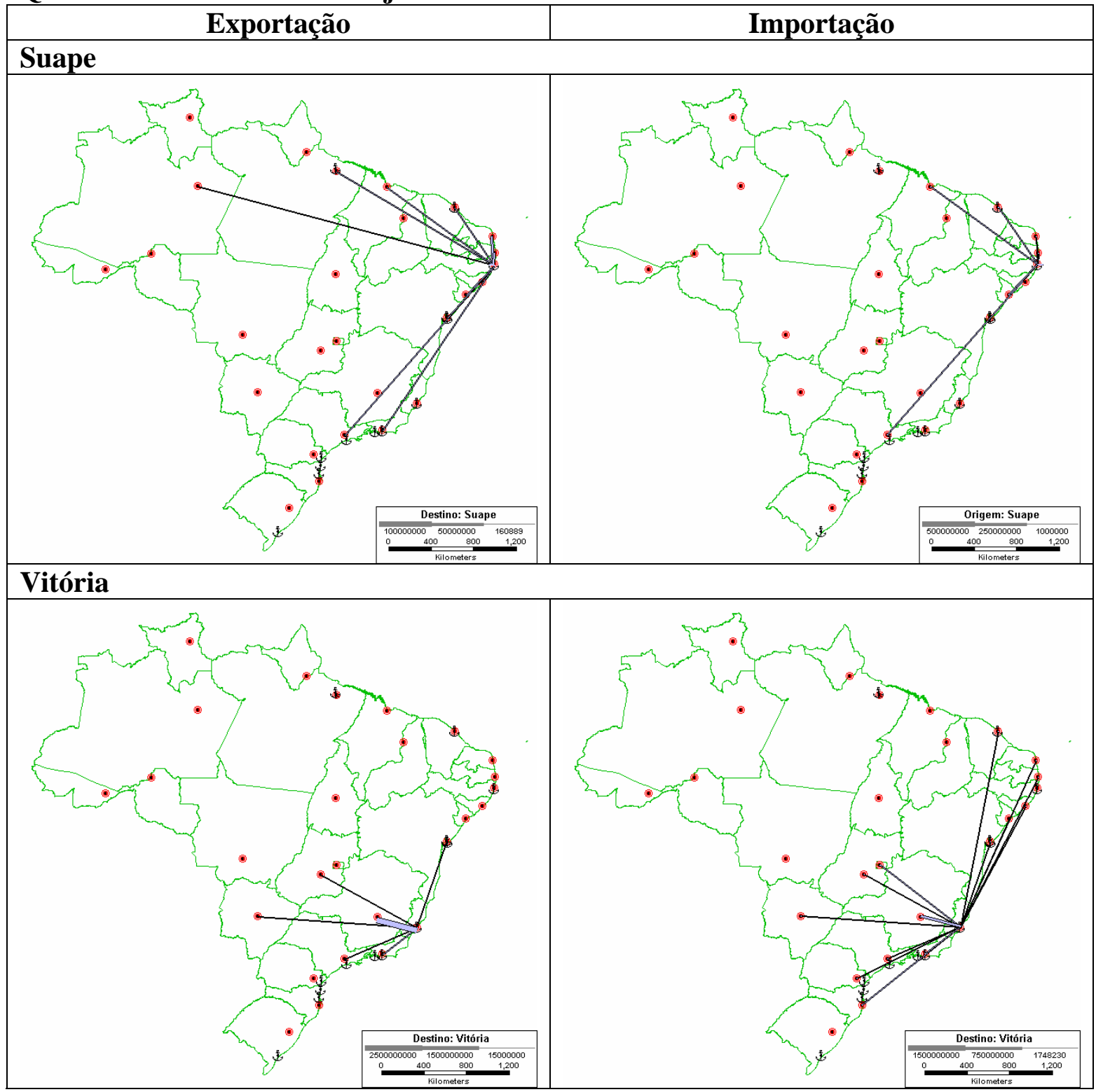

Fonte: MDIC, Aliceweb. 
Tabela A.1.1 - Participação das importações estaduais no total importado por porto de entrada (\%)

\begin{tabular}{|c|c|c|c|c|c|c|c|}
\hline Estado & Aratu & Belém & Fortaleza & Itajaí & Paranaguá & Rio Grande & Rio de Janeiro \\
\hline Acre & 0,00 & 0,00 & 0,00 & 0,00 & 0,11 & 0,00 & 0,00 \\
\hline Alagoas & 0,00 & 0,00 & 0,01 & 0,00 & 0,01 & 0,00 & 0,02 \\
\hline Amapá & 0,00 & 0,00 & 0,00 & 0,00 & 0,00 & 0,00 & 0,00 \\
\hline Amazonas & 0,00 & 0,00 & 0,00 & 0,02 & 0,17 & 0,00 & 0,13 \\
\hline Bahia & 93,90 & 0,00 & 0,01 & 0,03 & 0,02 & 0,06 & 0,24 \\
\hline Ceará & 0,00 & 0,00 & 96,18 & 0,01 & 0,00 & 0,06 & 0,00 \\
\hline Distrito Federal & 0,00 & 0,86 & 0,01 & 0,15 & 0,43 & 0,10 & 1,08 \\
\hline Espírito Santo & 0,02 & 0,00 & 0,00 & 0,80 & 0,06 & 0,00 & 2,84 \\
\hline Goiás & 0,00 & 0,00 & 0,00 & 0,31 & 1,96 & 0,01 & 0,23 \\
\hline Maranhão & 0,00 & 21,63 & 1,31 & 0,00 & 0,00 & 0,00 & 0,02 \\
\hline Mato Grosso & 0,00 & 0,00 & 0,00 & 0,31 & 0,47 & 0,00 & 0,09 \\
\hline Mato Grosso do Sul & 0,00 & 0,00 & 0,00 & 0,06 & 3,75 & 1,16 & 0,02 \\
\hline Minas Gerais & 0,00 & 0,01 & 0,07 & 2,84 & 0,55 & 0,08 & 25,10 \\
\hline Pará & 0,00 & 76,28 & 0,06 & 0,00 & 0,00 & 0,02 & 0,07 \\
\hline Paraíba & 0,00 & 0,00 & 0,02 & 0,00 & 0,00 & 0,03 & 0,00 \\
\hline Paraná & 0,00 & 0,00 & 0,00 & 6,94 & 85,55 & 1,22 & 0,24 \\
\hline Pernambuco & 3,85 & 0,01 & 0,12 & 0,02 & 0,09 & 0,01 & 0,08 \\
\hline Piauí & 0,00 & 0,00 & 0,89 & 0,00 & 0,00 & 0,00 & 0,00 \\
\hline Rio de Janeiro & 0,00 & 0,06 & 0,04 & 0,77 & 0,61 & 0,20 & 63,03 \\
\hline Rio Grande do Norte & 0,00 & 0,00 & 1,11 & 0,00 & 0,00 & 0,00 & 0,01 \\
\hline Rio Grande do Sul & 0,00 & 0,00 & 0,01 & 3,26 & 0,44 & 95,59 & 0,50 \\
\hline Rondônia & 0,00 & 0,00 & 0,00 & 0,00 & 0,01 & 0,00 & 0,00 \\
\hline Roraima & 0,00 & 0,00 & 0,00 & 0,00 & 0,00 & 0,00 & 0,00 \\
\hline Santa Catarina & 0,00 & 0,00 & 0,00 & 74,51 & 1,45 & 0,70 & 0,18 \\
\hline São Paulo & 2,23 & 1,16 & 0,13 & 9,96 & 4,33 & 0,74 & 6,01 \\
\hline Sergipe & 0,00 & 0,00 & 0,00 & 0,00 & 0,00 & 0,00 & 0,09 \\
\hline Tocantins & 0,00 & 0,00 & 0,00 & 0,00 & 0,00 & 0,00 & 0,02 \\
\hline Total & 100,00 & 100,00 & 100,00 & 100,00 & 100,00 & 100,00 & 100,00 \\
\hline
\end{tabular}


Tabela A.1.1 - Participação das importações estaduais no total importado por porto de entrada (\%), final

\begin{tabular}{|c|c|c|c|c|c|c|}
\hline Estado & Salvador & Santos & Sepetiba & São Francisco do Sul & Suape & Vitória \\
\hline$\overline{\text { Acre }}$ & 0,00 & 0,00 & 0,00 & 0,00 & 0,00 & 0,00 \\
\hline Alagoas & 0,23 & 0,06 & 0,00 & 0,00 & 0,00 & 2,07 \\
\hline Amapá & 0,00 & 0,00 & 0,00 & 0,00 & 0,00 & 0,00 \\
\hline Amazonas & 0,00 & 0,01 & 0,04 & 0,12 & 0,00 & 0,00 \\
\hline Bahia & 94,36 & 0,29 & 0,02 & 0,02 & 0,08 & 0,87 \\
\hline Ceará & 0,44 & 0,03 & 0,00 & 0,00 & 0,98 & 0,96 \\
\hline Distrito Federal & 0,09 & 0,86 & 0,28 & 1,46 & 0,03 & 0,14 \\
\hline Espírito Santo & 0,36 & 0,27 & 0,08 & 0,18 & 0,00 & 60,28 \\
\hline Goiás & 0,01 & 1,20 & 0,00 & 0,37 & 0,03 & 2,59 \\
\hline Maranhão & 0,00 & 0,00 & 0,00 & 0,00 & 0,15 & 0,02 \\
\hline Mato Grosso & 0,00 & 0,48 & 0,08 & 0,00 & 0,00 & 0,02 \\
\hline Mato Grosso do Sul & 0,00 & 0,17 & 0,00 & 1,92 & 0,00 & 0,07 \\
\hline Minas Gerais & 0,58 & 4,08 & 5,28 & 0,06 & 0,00 & 27,87 \\
\hline Pará & 0,05 & 0,02 & 0,01 & 0,01 & 0,01 & 0,01 \\
\hline Paraíba & 0,03 & 0,01 & 0,00 & 0,00 & 2,98 & 0,07 \\
\hline Paraná & 0,01 & 1,46 & 0,04 & 57,66 & 0,02 & 0,13 \\
\hline Pernambuco & 0,21 & 0,13 & 0,00 & 0,00 & 90,17 & 0,05 \\
\hline Piauí & 0,00 & 0,00 & 0,00 & 0,00 & 0,00 & 0,00 \\
\hline Rio de Janeiro & 0,01 & 1,24 & 92,66 & 0,02 & 0,06 & 0,93 \\
\hline Rio Grande do Norte & 0,39 & 0,16 & 0,00 & 0,00 & 3,12 & 1,17 \\
\hline Rio Grande do Sul & 0,00 & 1,36 & 0,00 & 1,53 & 0,00 & 0,01 \\
\hline Rondônia & 0,00 & 0,00 & 0,33 & 0,02 & 0,00 & 0,00 \\
\hline Roraima & 0,00 & 0,00 & 0,00 & 0,00 & 0,00 & 0,00 \\
\hline Santa Catarina & 0,04 & 0,10 & 0,00 & 32,26 & 0,00 & 0,12 \\
\hline São Paulo & 0,55 & 87,87 & 1,14 & 4,38 & 0,46 & 1,73 \\
\hline Sergipe & 2,62 & 0,04 & 0,03 & 0,00 & 1,91 & 0,90 \\
\hline Tocantins & 0,00 & 0,17 & 0,00 & 0,00 & 0,00 & 0,00 \\
\hline Total & 100,00 & 100,00 & 100,00 & 100,00 & 100,00 & 100,00 \\
\hline
\end{tabular}

Fonte: MDIC, Aliceweb 
Tabela A.1.2 - Participação das exportações estaduais no total exportado por porto de entrada (\%)

\begin{tabular}{|c|c|c|c|c|c|c|c|}
\hline Estado & Aratu & Belém & Fortaleza & Itajaí & Paranaguá & Rio Grande & Rio de Janeiro \\
\hline$\overline{\text { Acre }}$ & 0,00 & 0,00 & 0,00 & 0,09 & 0,02 & 0,01 & 0,00 \\
\hline Alagoas & 0,00 & 0,00 & 0,14 & 0,00 & 0,00 & 0,00 & 0,00 \\
\hline Amapá & 0,00 & 0,21 & 0,01 & 0,00 & 0,00 & 0,00 & 0,02 \\
\hline Amazonas & 0,00 & 0,22 & 0,00 & 0,02 & 0,01 & 0,00 & 0,46 \\
\hline Bahia & 99,92 & 0,03 & 1,00 & 0,01 & 0,01 & 0,13 & 1,27 \\
\hline Ceará & 0,00 & 0,05 & 69,43 & 0,00 & 0,00 & 0,08 & 0,01 \\
\hline Distrito Federal & 0,00 & 0,00 & 0,00 & 0,00 & 0,00 & 0,00 & 0,00 \\
\hline Espírito Santo & 0,00 & 0,00 & 0,00 & 0,00 & 0,00 & 0,00 & 2,00 \\
\hline Goiás & 0,00 & 0,00 & 0,00 & 1,40 & 0,86 & 0,01 & 0,06 \\
\hline Maranhão & 0,00 & 3,32 & 0,20 & 0,00 & 0,00 & 0,04 & 0,01 \\
\hline Mato Grosso & 0,00 & 0,00 & 0,00 & 2,81 & 1,77 & 0,05 & 0,00 \\
\hline Mato Grosso do Sul & 0,00 & 0,05 & 0,00 & 0,94 & 6,61 & 0,09 & 0,01 \\
\hline Minas Gerais & 0,00 & 0,07 & 0,01 & 0,00 & 0,87 & 0,02 & 0,00 \\
\hline Pará & 0,00 & 94,64 & 0,44 & 0,01 & 0,07 & 0,01 & 0,02 \\
\hline Paraíba & 0,00 & 0,00 & 4,78 & 0,00 & 0,00 & 0,01 & 0,00 \\
\hline Paraná & 0,00 & 0,04 & 0,00 & 20,55 & 74,78 & 0,61 & 1,01 \\
\hline Pernambuco & 0,00 & 0,04 & 2,72 & 0,00 & 0,00 & 0,03 & 0,02 \\
\hline Piauí & 0,00 & 0,00 & 5,36 & 0,00 & 0,00 & 0,00 & 0,00 \\
\hline Rio de Janeiro & 0,01 & 0,00 & 0,05 & 0,04 & 0,09 & 0,21 & 71,46 \\
\hline Rio Grande do Norte & 0,00 & 0,00 & 13,14 & 0,00 & 0,00 & 0,00 & 0,00 \\
\hline Rio Grande do Sul & 0,00 & 0,08 & 2,50 & 13,01 & 1,23 & 97,94 & 0,44 \\
\hline Rondônia & 0,00 & 0,13 & 0,00 & 0,27 & 0,90 & 0,00 & 0,10 \\
\hline Roraima & 0,00 & 0,00 & 0,00 & 0,00 & 0,01 & 0,00 & 0,00 \\
\hline Santa Catarina & 0,00 & 0,01 & 0,00 & 55,71 & 4,36 & 0,00 & 0,00 \\
\hline São Paulo & 0,07 & 1,11 & 0,21 & 5,14 & 8,39 & 0,77 & 23,10 \\
\hline Sergipe & 0,00 & 0,00 & 0,01 & 0,00 & 0,00 & 0,00 & 0,00 \\
\hline Tocantins & 0,00 & 0,00 & 0,00 & 0,00 & 0,01 & 0,00 & 0,00 \\
\hline Total & 100,00 & 100,00 & 100,00 & 100,00 & 100,00 & 100,00 & 100,00 \\
\hline
\end{tabular}

Fonte: MDIC, Aliceweb. 
Tabela A.1.2 - Participação das exportações estaduais no total exportado por porto de entrada (\%), final

\begin{tabular}{|c|c|c|c|c|c|c|}
\hline Estado & Salvador & Santos & Sepetiba & São Francisco do Sul & Suape & Vitória \\
\hline Acre & 0,00 & 0,00 & 0,00 & 0,00 & 0,00 & 0,00 \\
\hline Alagoas & 0,43 & 0,00 & 0,00 & 0,00 & 3,18 & 0,00 \\
\hline Amapá & 0,00 & 0,00 & 0,00 & 0,00 & 0,00 & 0,00 \\
\hline Amazonas & 0,11 & 0,05 & 0,00 & 0,00 & 0,07 & 0,00 \\
\hline Bahia & 97,16 & 0,22 & 0,00 & 0,03 & 4,79 & 3,76 \\
\hline Ceará & 0,01 & 0,00 & 0,00 & 0,00 & 1,43 & 0,01 \\
\hline Distrito Federal & 0,00 & 0,01 & 0,00 & 0,00 & 0,00 & 0,00 \\
\hline Espírito Santo & 0,19 & 0,00 & 0,18 & 0,00 & 0,00 & 43,29 \\
\hline Goiás & 0,00 & 1,73 & 0,01 & 0,47 & 0,00 & 3,37 \\
\hline Maranhão & 0,00 & 0,00 & 0,00 & 0,00 & 0,39 & 0,00 \\
\hline Mato Grosso & 0,00 & 0,61 & 0,00 & 0,00 & 0,00 & 0,00 \\
\hline Mato Grosso do Sul & 0,00 & 5,25 & 0,00 & 0,00 & 0,00 & 2,74 \\
\hline Minas Gerais & 0,30 & 7,72 & 0,00 & 0,99 & 0,00 & 46,17 \\
\hline Pará & 0,00 & 0,04 & 0,00 & 0,01 & 0,23 & 0,00 \\
\hline Paraíba & 0,09 & 0,03 & 0,00 & 0,00 & 19,28 & 0,00 \\
\hline Paraná & 0,00 & 1,55 & 0,05 & 26,64 & 0,00 & 0,02 \\
\hline Pernambuco & 0,00 & 0,00 & 0,00 & 0,00 & 47,63 & 0,00 \\
\hline Piauí & 0,09 & 0,00 & 0,00 & 0,00 & 0,00 & 0,00 \\
\hline Rio de Janeiro & 0,03 & 0,00 & 98,97 & 0,08 & 0,29 & 0,25 \\
\hline Rio Grande do Norte & 0,02 & 0,00 & 0,00 & 0,00 & 21,29 & 0,00 \\
\hline Rio Grande do Sul & 0,05 & 0,77 & 0,03 & 0,00 & 0,04 & 0,00 \\
\hline Rondônia & 0,00 & 0,05 & 0,00 & 0,13 & 0,00 & 0,02 \\
\hline Roraima & 0,00 & 0,00 & 0,00 & 0,00 & 0,00 & 0,00 \\
\hline Santa Catarina & 0,00 & 0,12 & 0,00 & 71,64 & 0,00 & 0,00 \\
\hline São Paulo & 0,50 & 81,84 & 0,76 & 0,00 & 1,13 & 0,37 \\
\hline Sergipe & 1,01 & 0,01 & 0,00 & 0,00 & 0,25 & 0,00 \\
\hline Tocantins & 0,00 & 0,01 & 0,00 & 0,00 & 0,00 & 0,00 \\
\hline Total & 100,00 & 100,00 & 100,00 & 100,00 & 100,00 & 100,00 \\
\hline
\end{tabular}

Fonte: MDIC, Aliceweb. 


\section{APÊNDICE A.2}

Quadro A.2 - Linhas de Desejo/UF

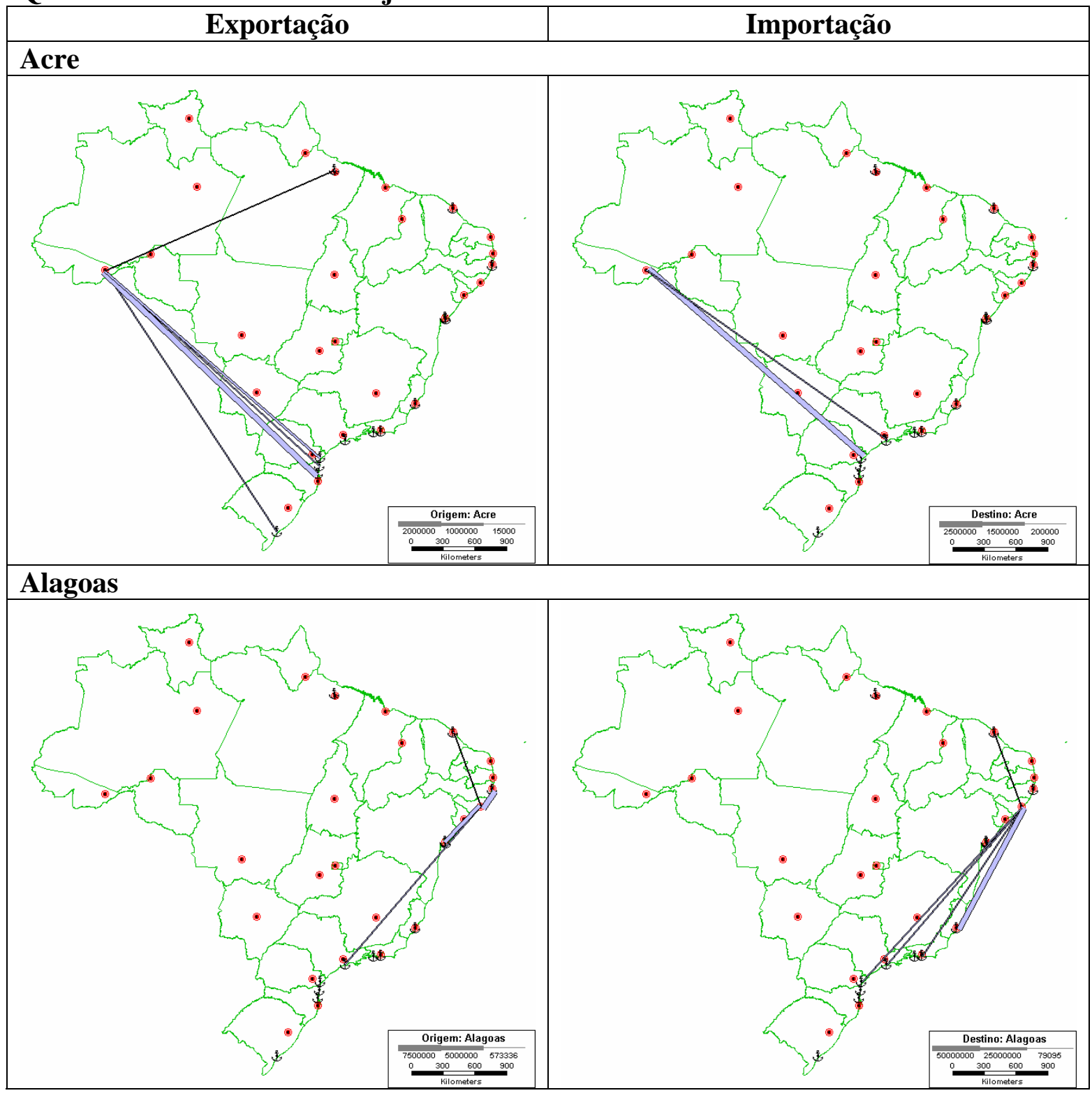

Fonte: MDIC, Aliceweb. 
Quadro A.2 - Linhas de Desejo/UF
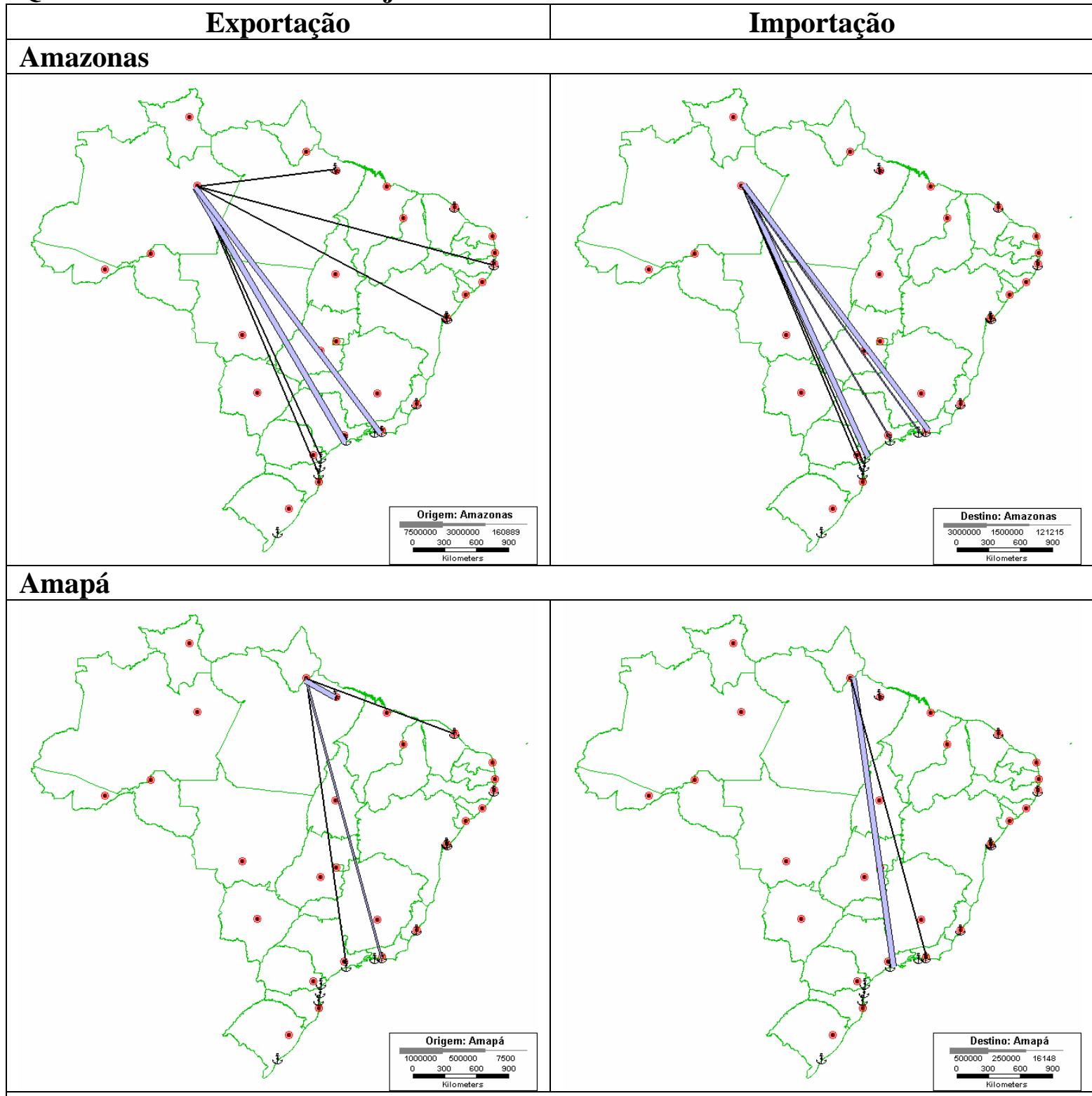

\section{Bahia}
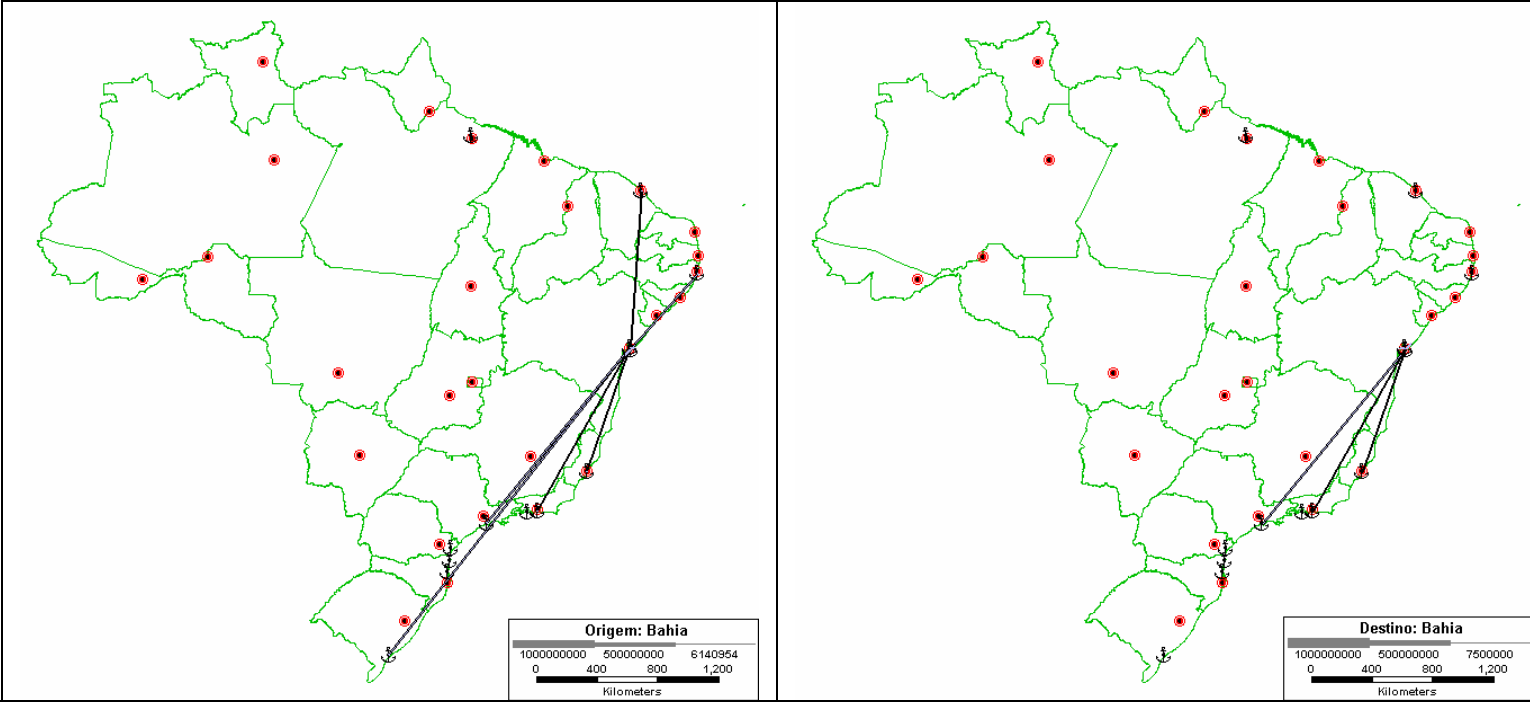

Fonte: MDIC, Aliceweb. 
Quadro A.2 - Linhas de Desejo/UF

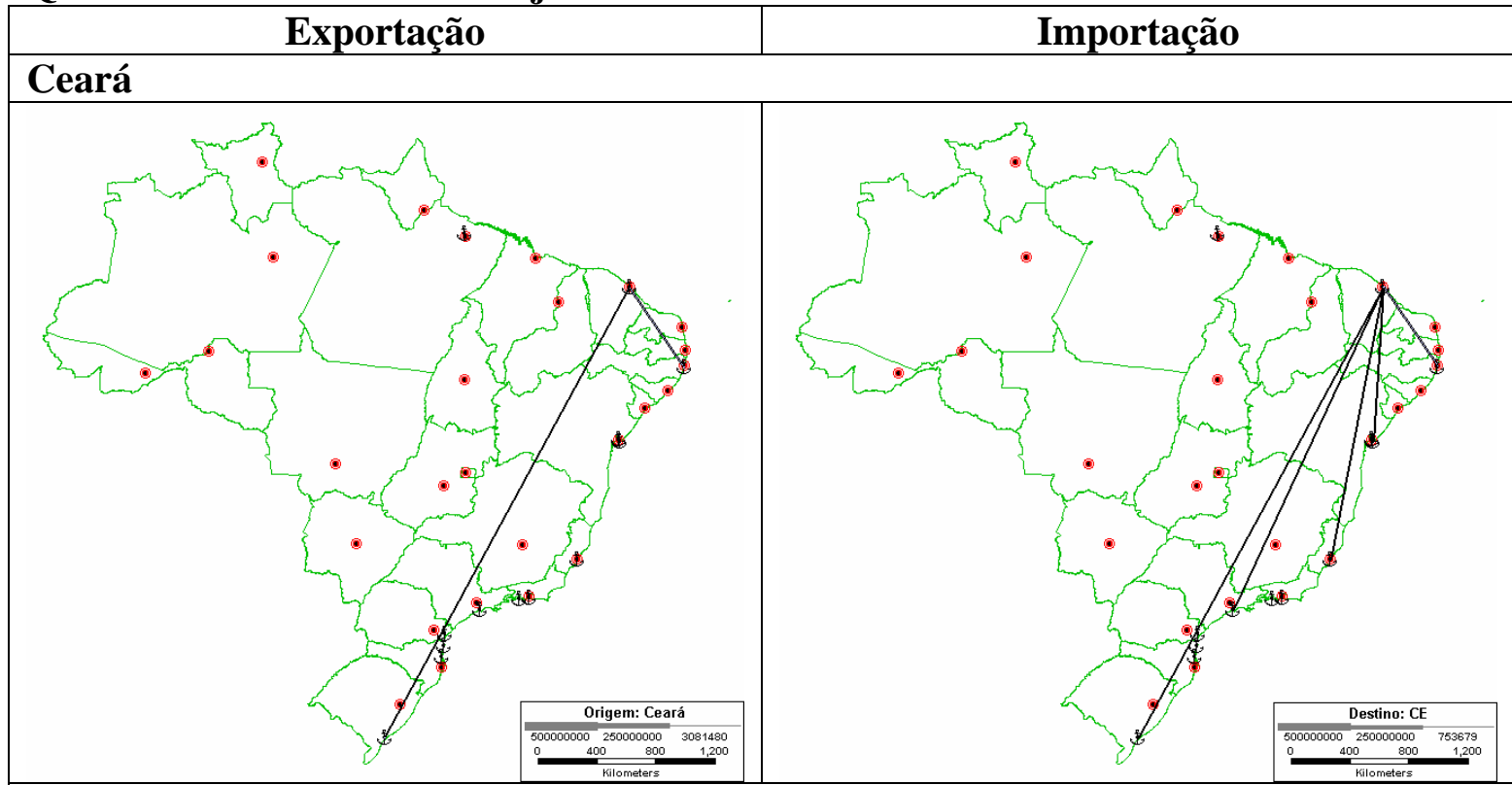

\section{Espírito Santo}

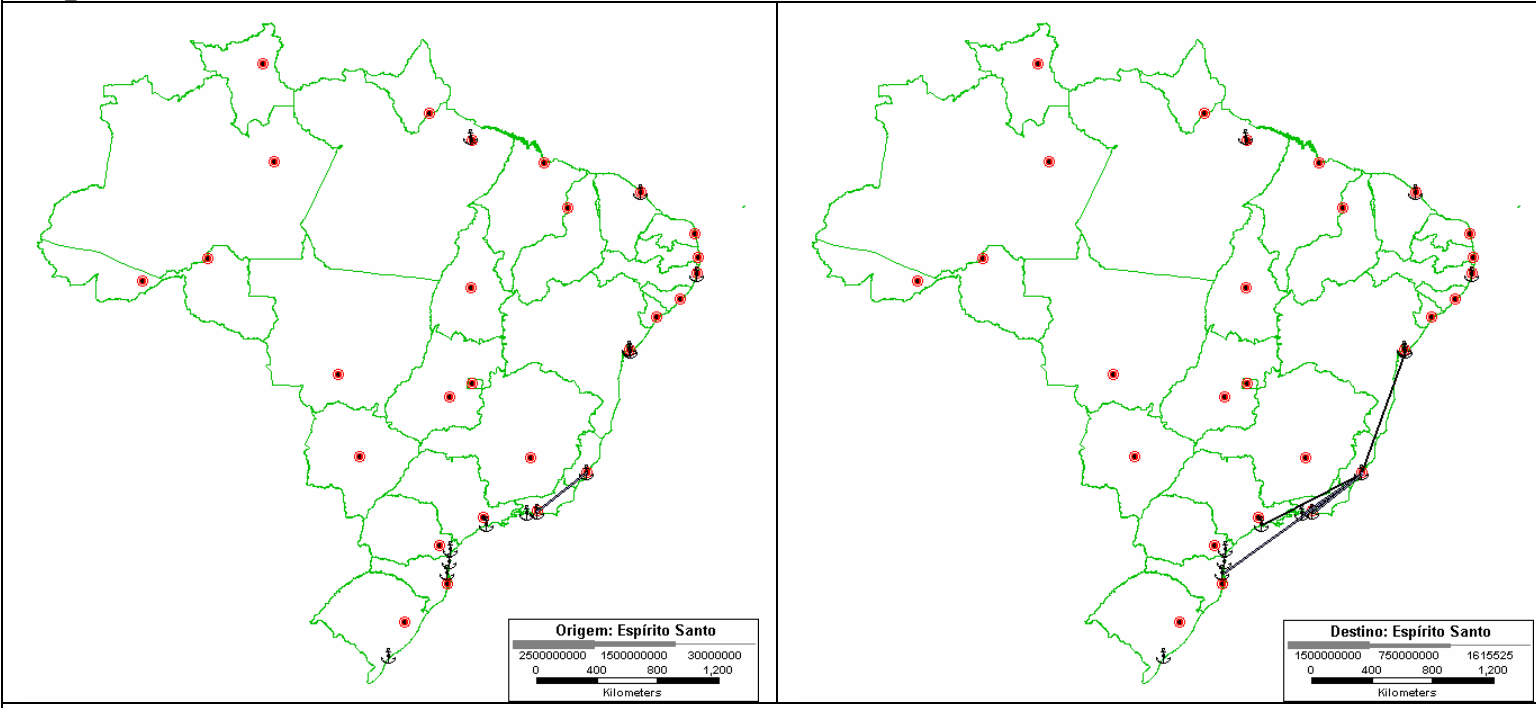

\section{Goiás}
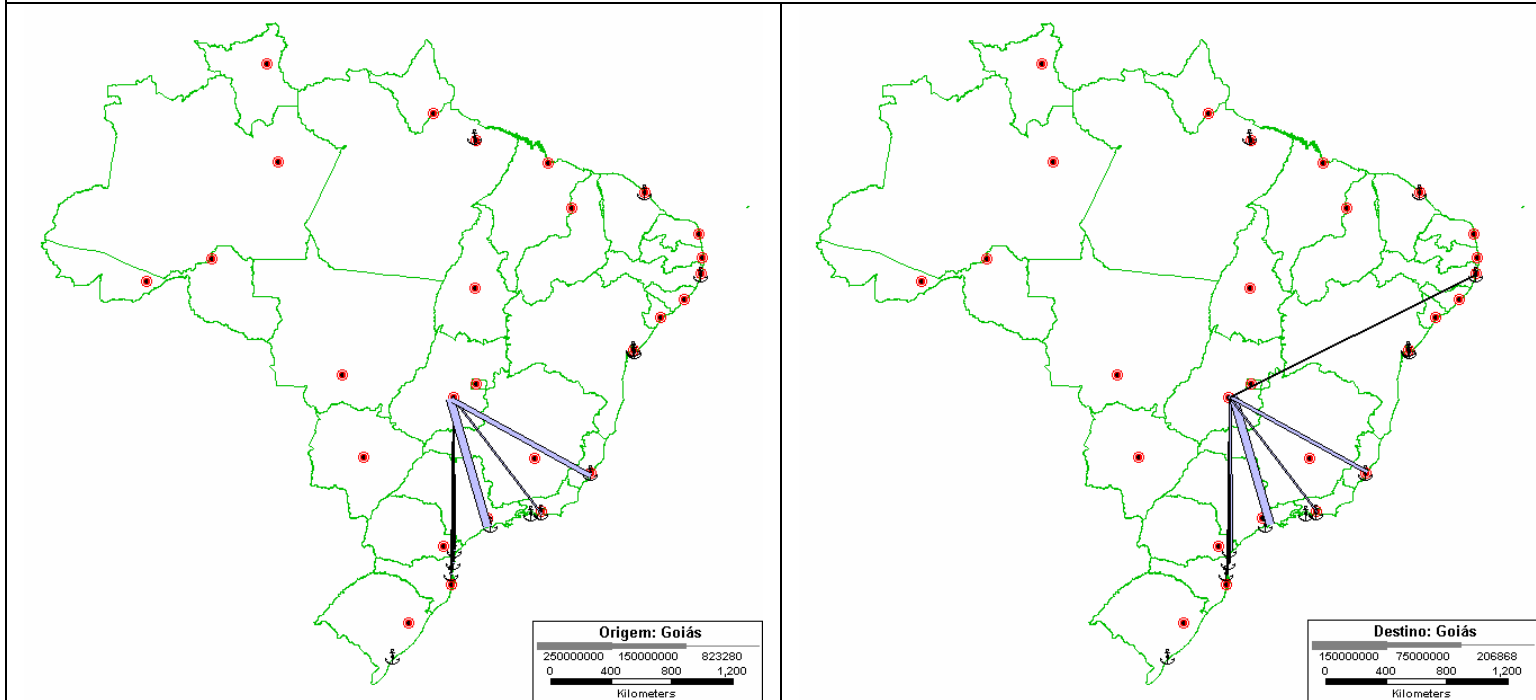

Fonte: MDIC, Aliceweb. 
Quadro A.2 - Linhas de Desejo/UF

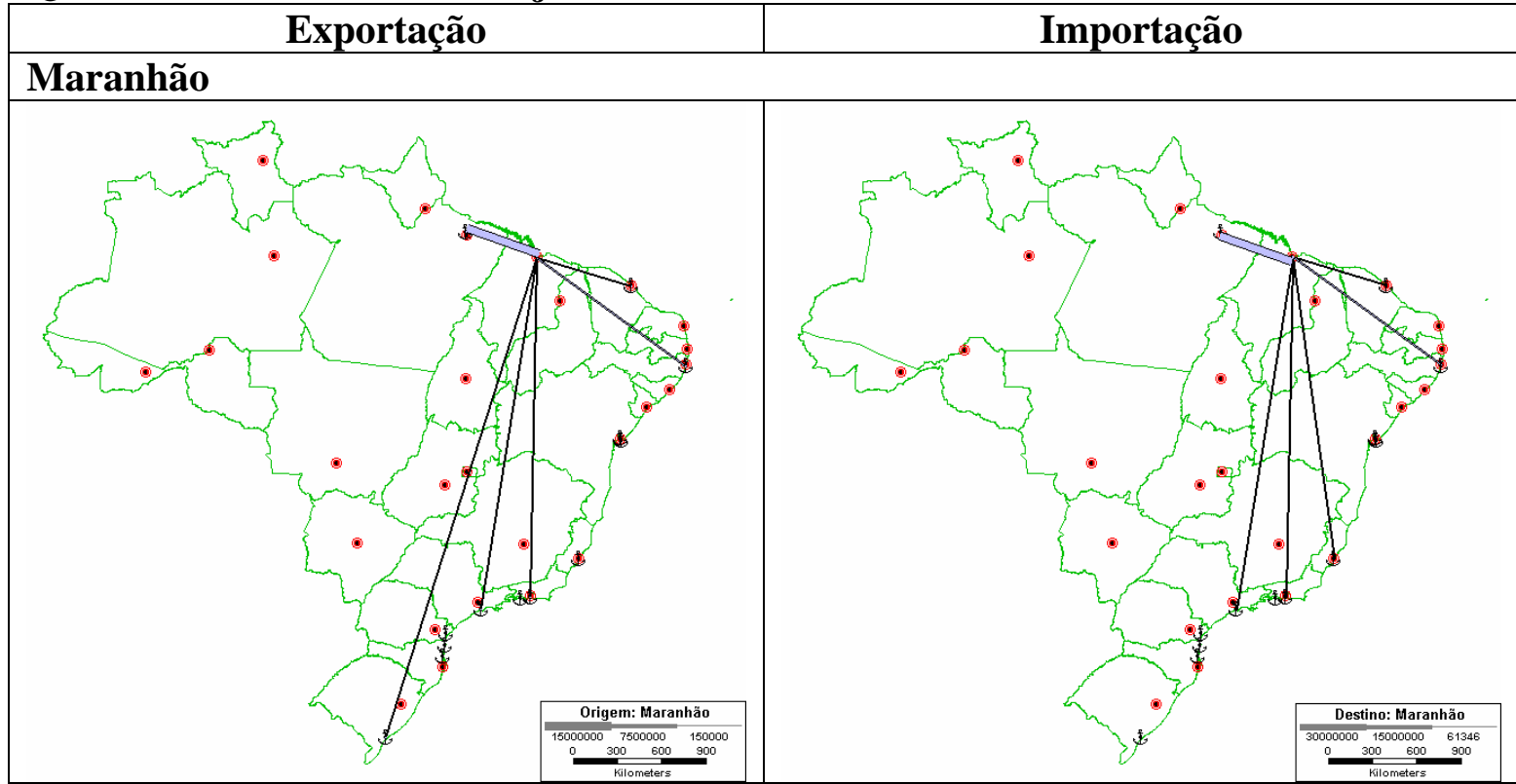

\section{Minas Gerais}

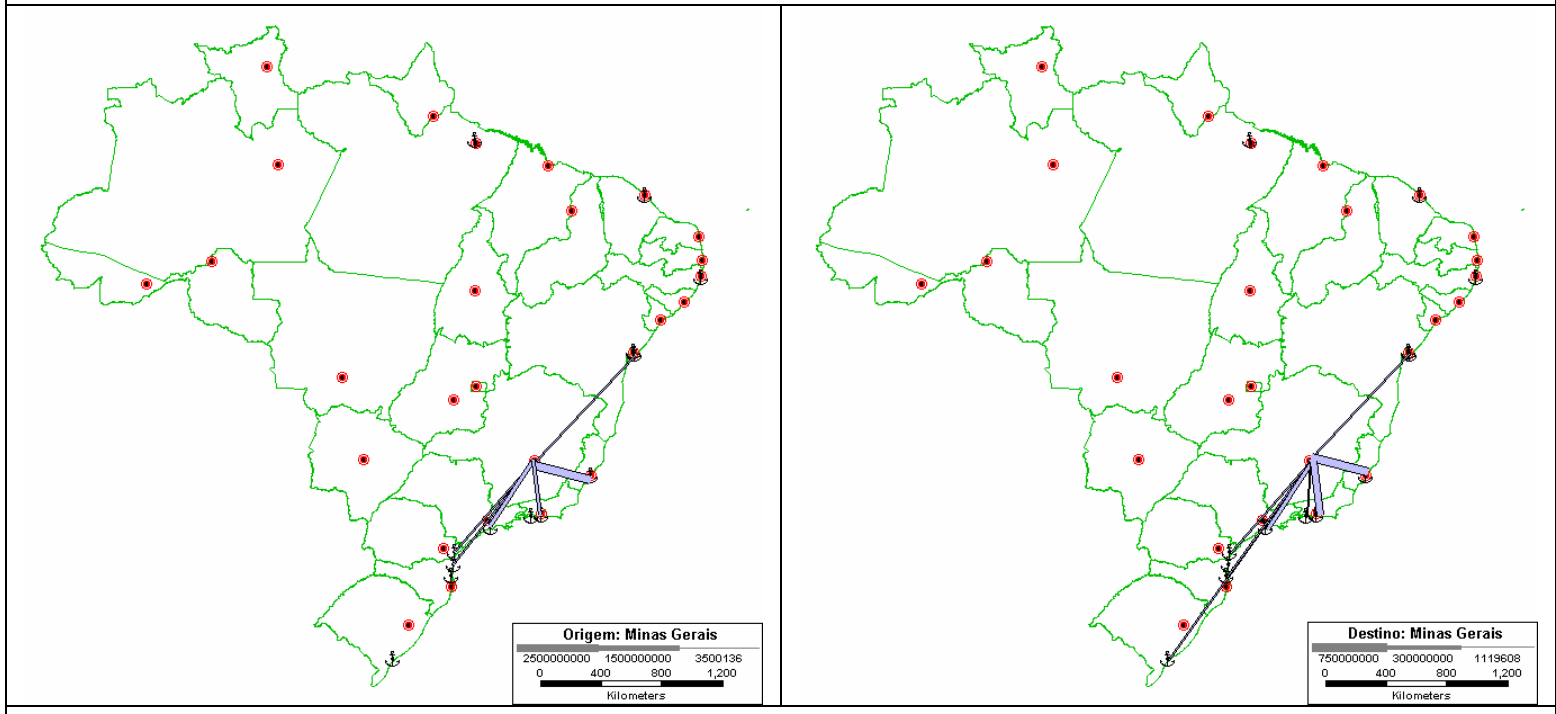

\section{Mato Grosso do Sul}
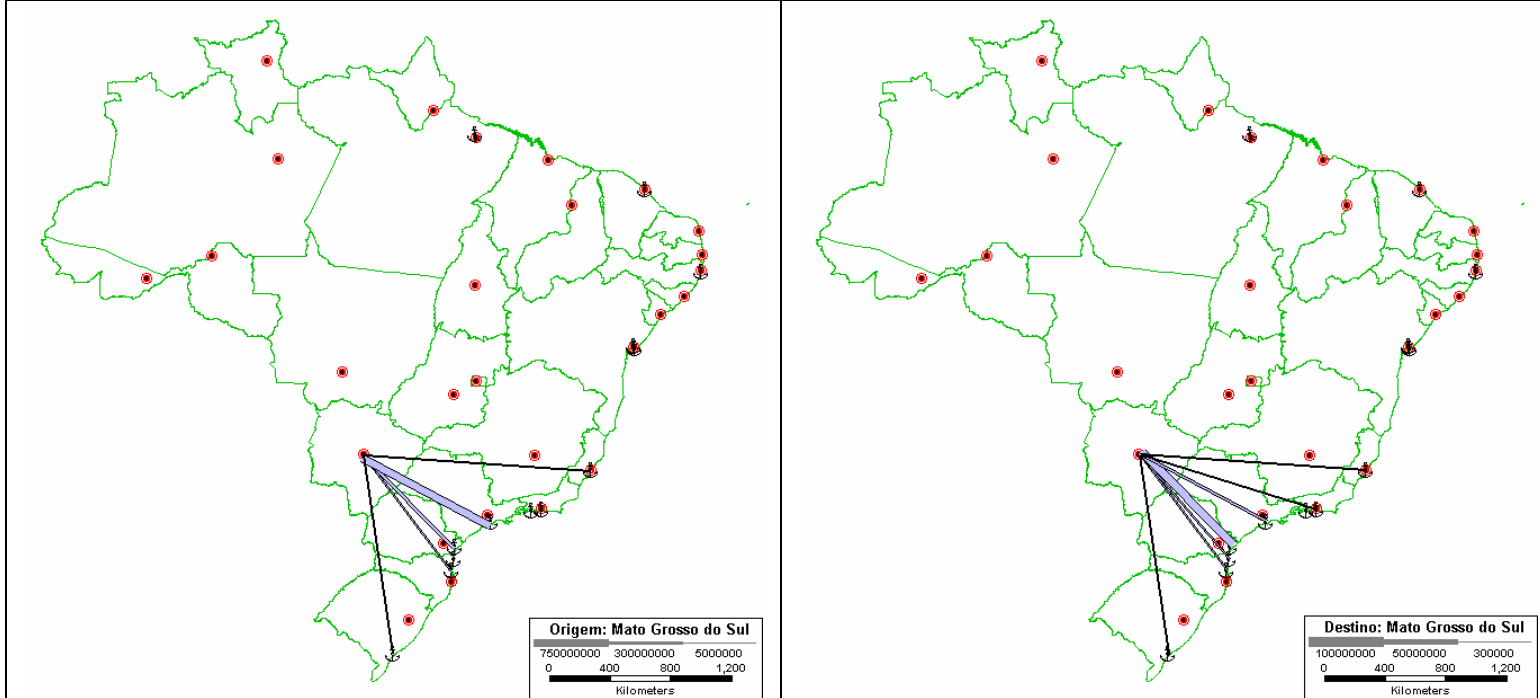

Fonte: MDIC, Aliceweb. 
Quadro A.2 - Linhas de Desejo/UF
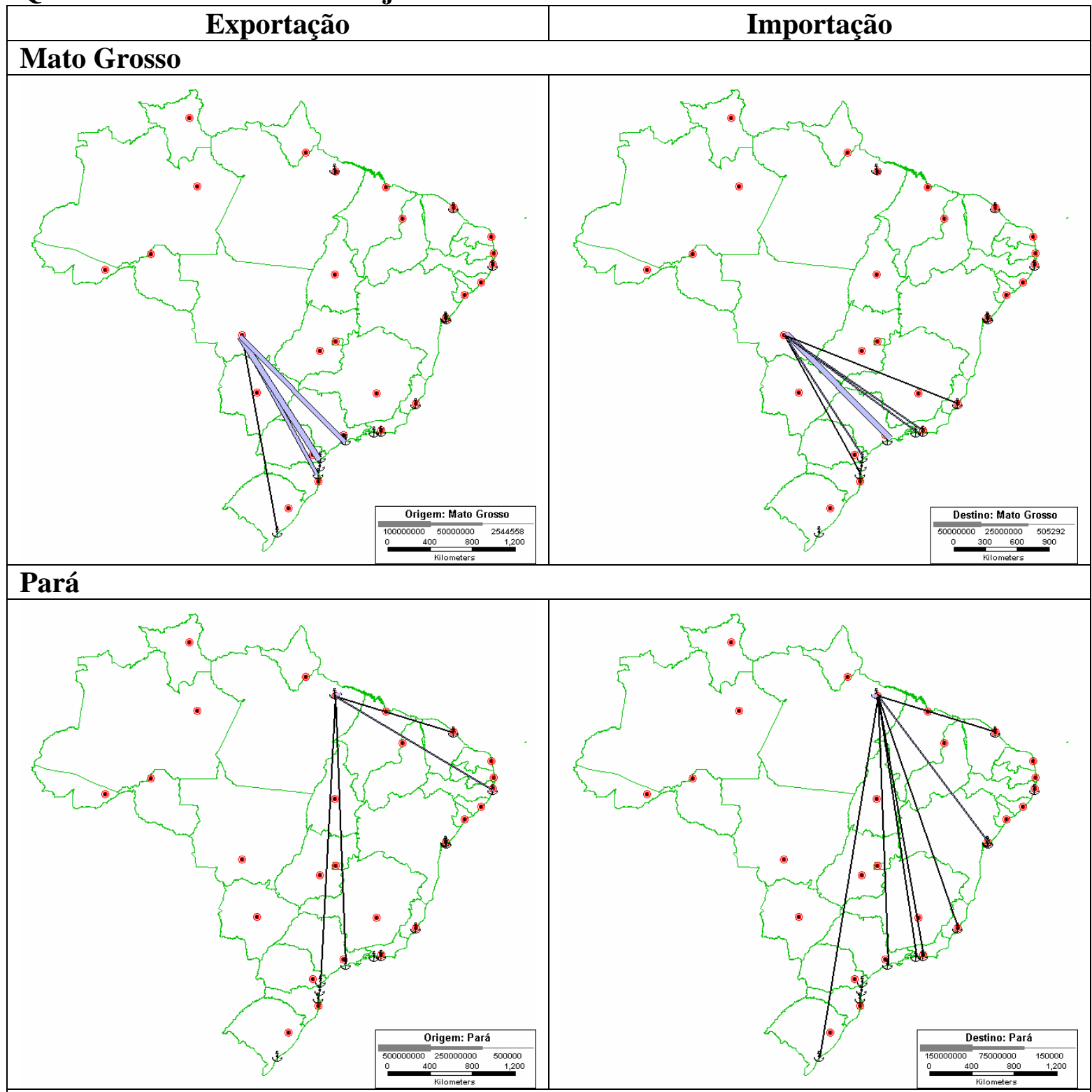

\section{Paraíba}
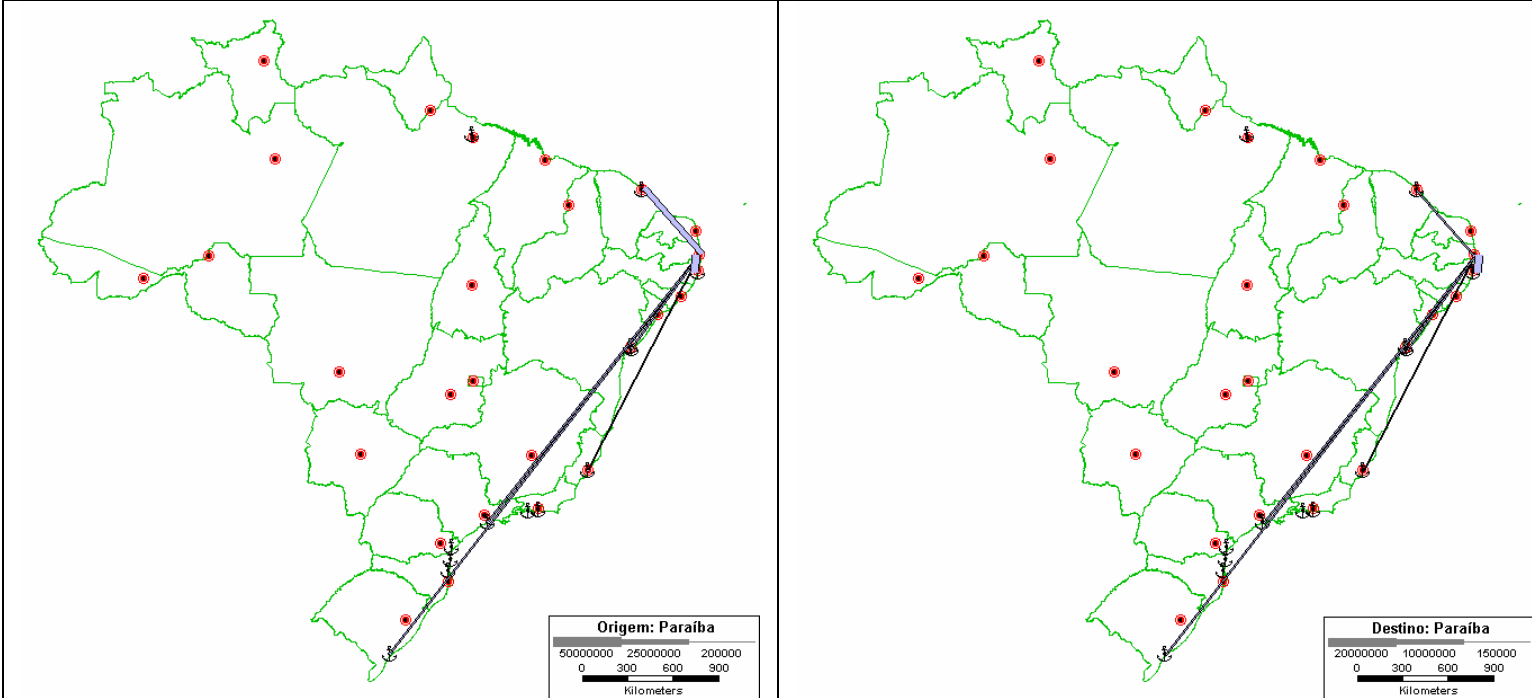

Fonte: MDIC, Aliceweb. 
Quadro A.2 - Linhas de Desejo/UF
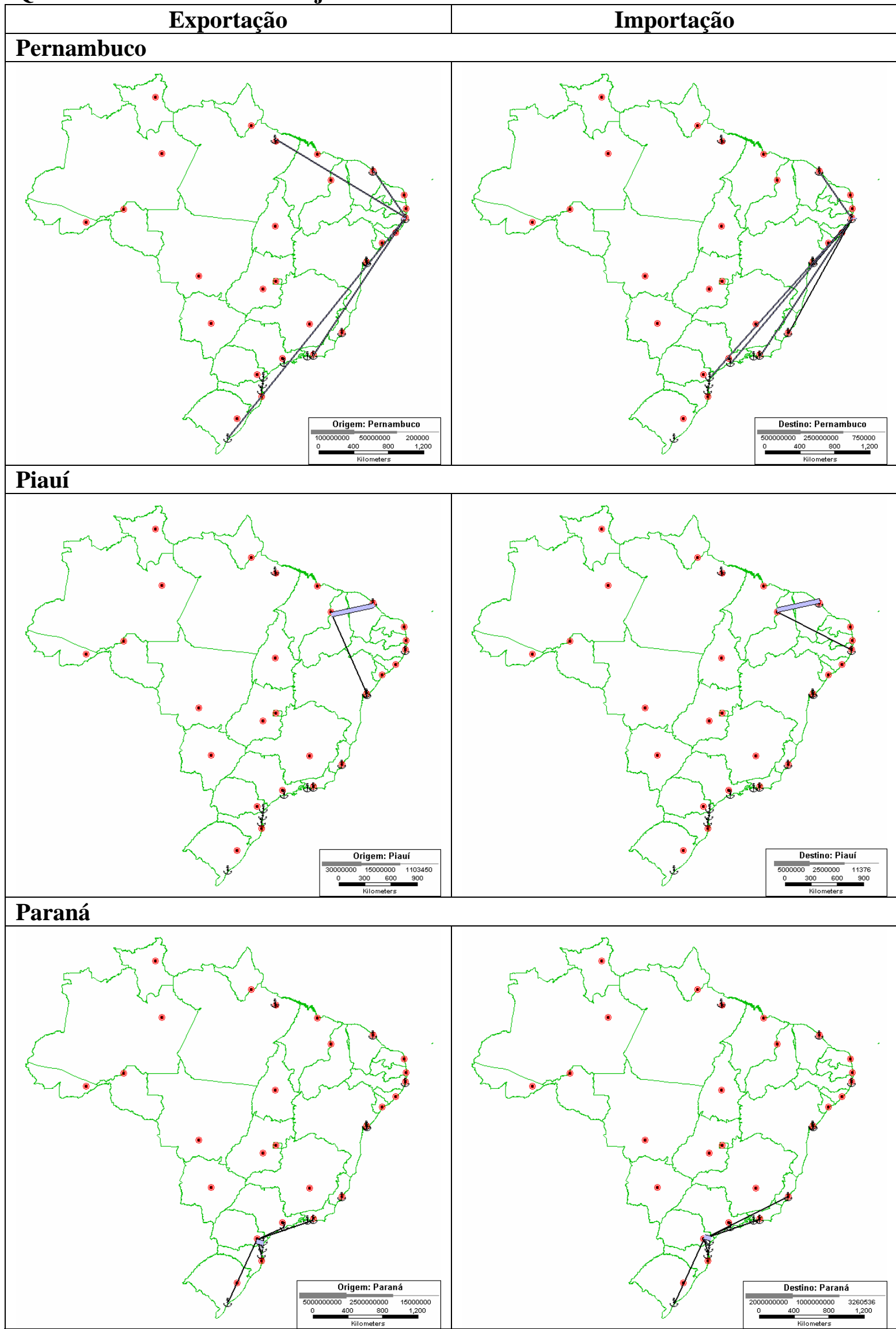

Fonte: MDIC, Aliceweb. 
Quadro A.2 - Linhas de Desejo/UF
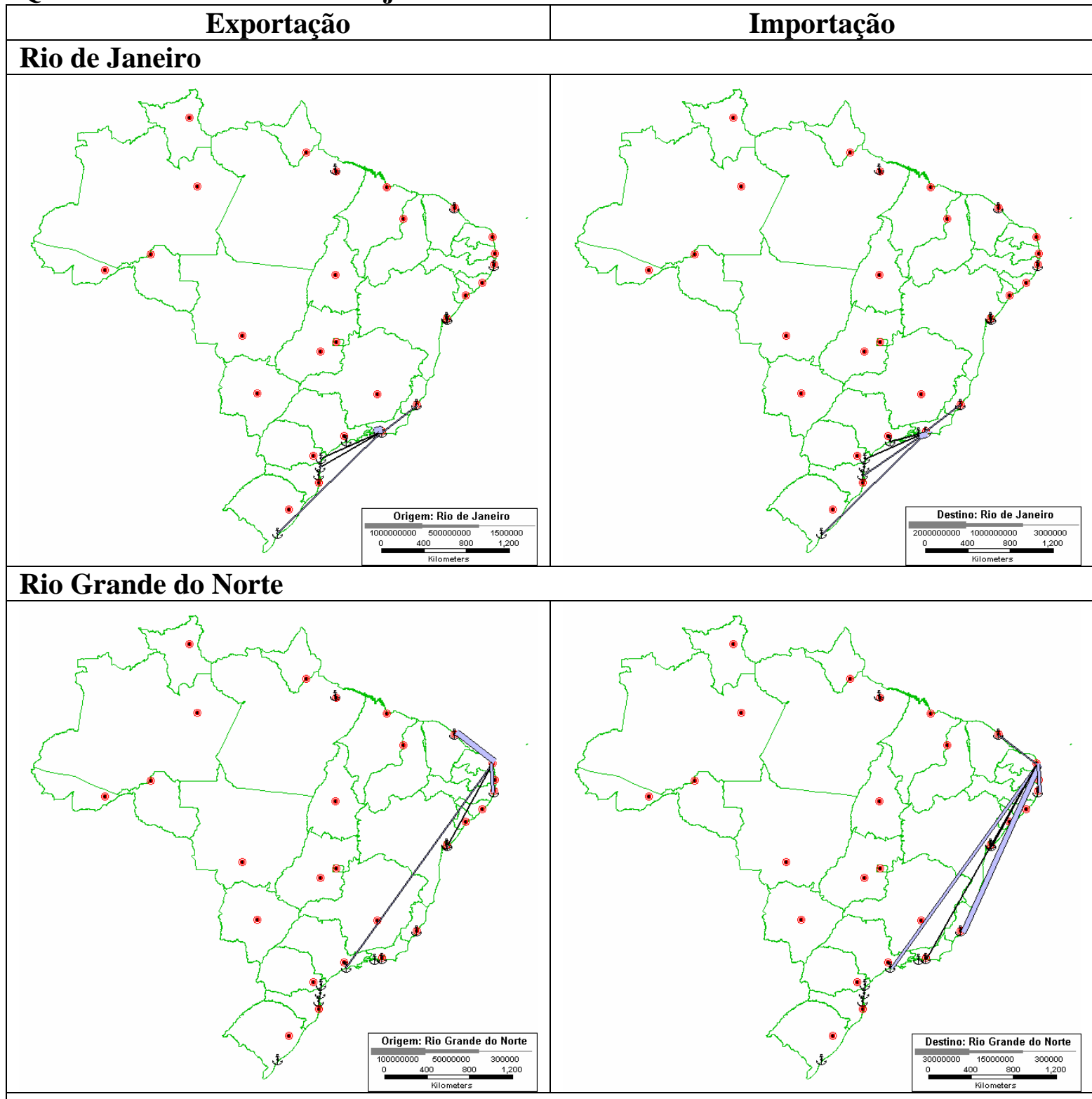

\section{Rondônia}
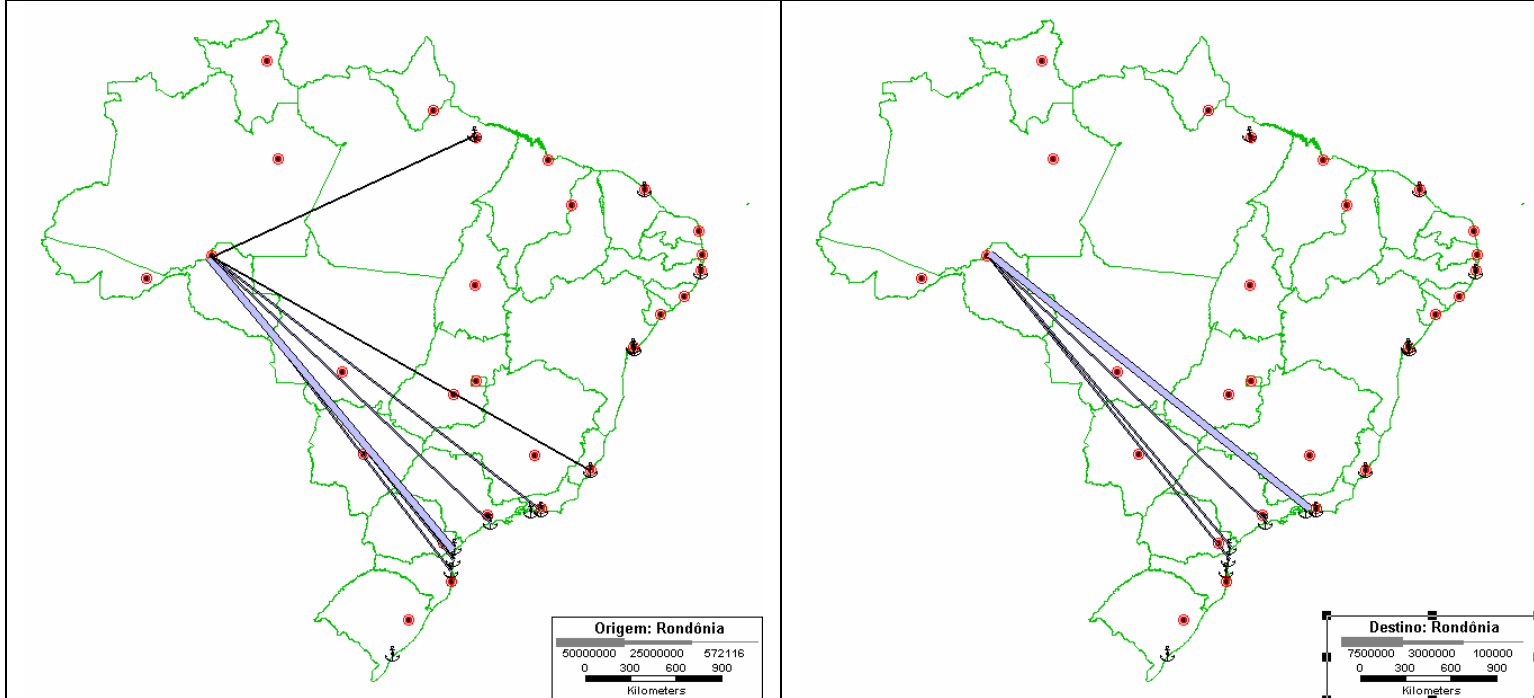

Fonte: MDIC, Aliceweb. 
Quadro A.2 - Linhas de Desejo/UF
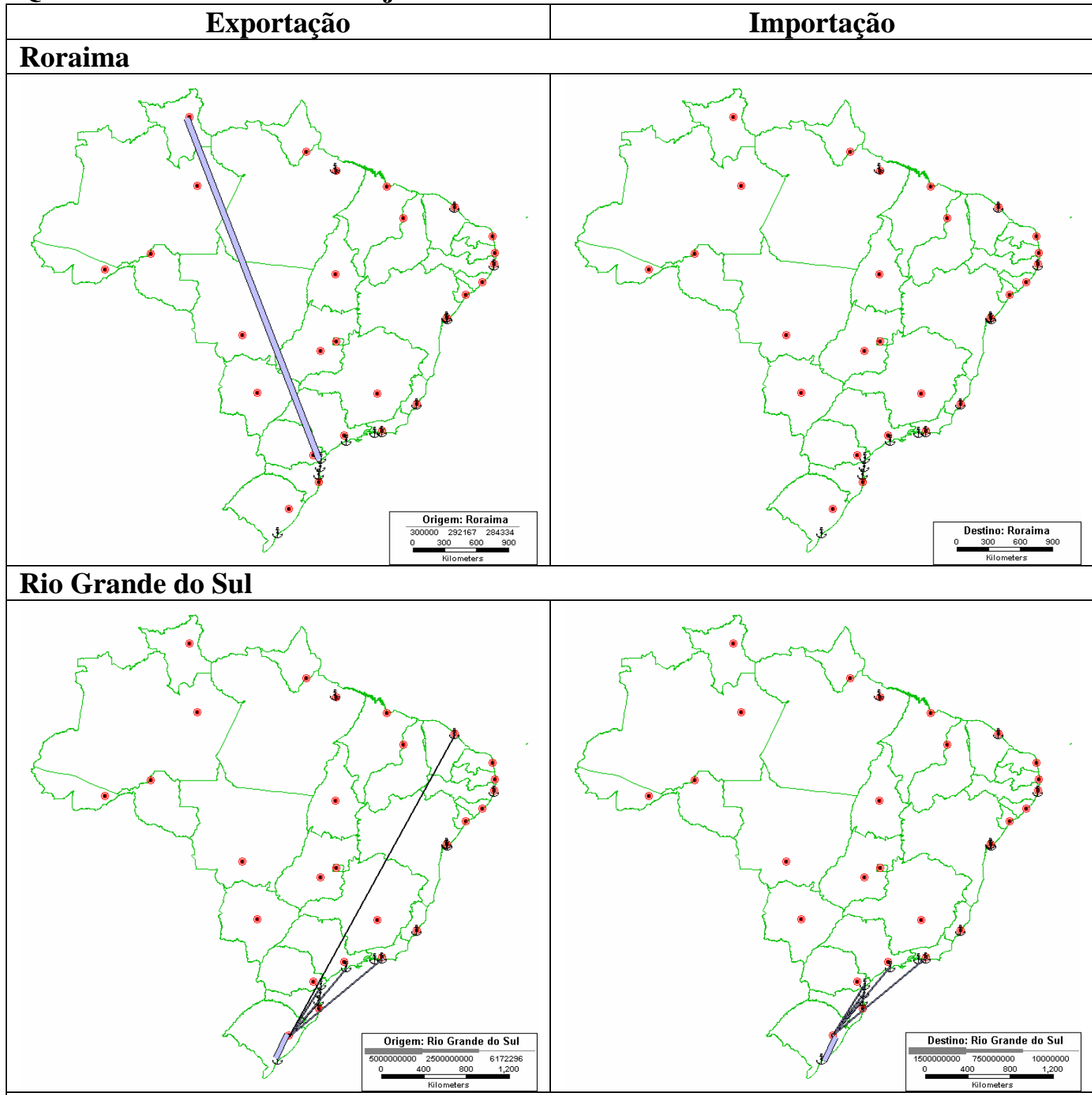

\section{Santa Catarina}
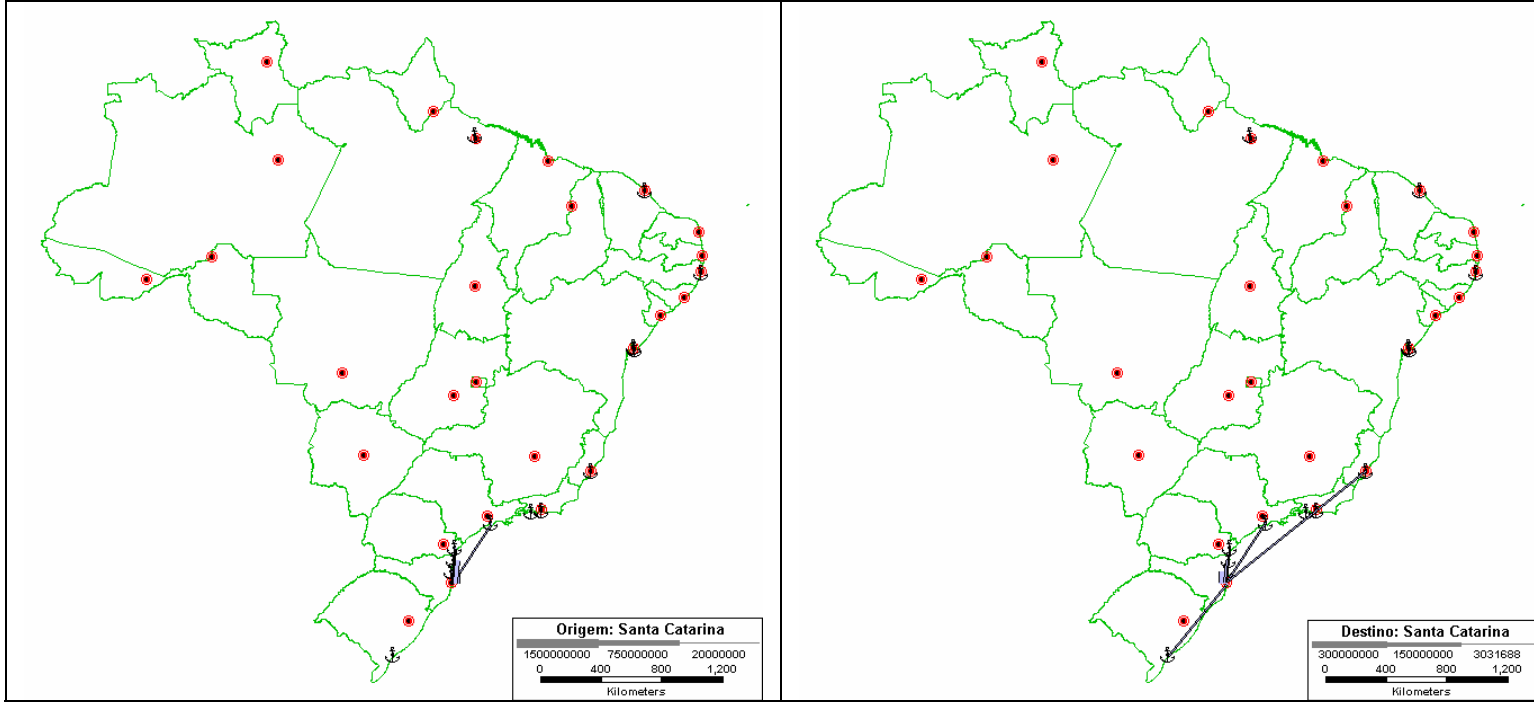

Fonte: MDIC, Aliceweb. 
Quadro A.2 - Linhas de Desejo/UF

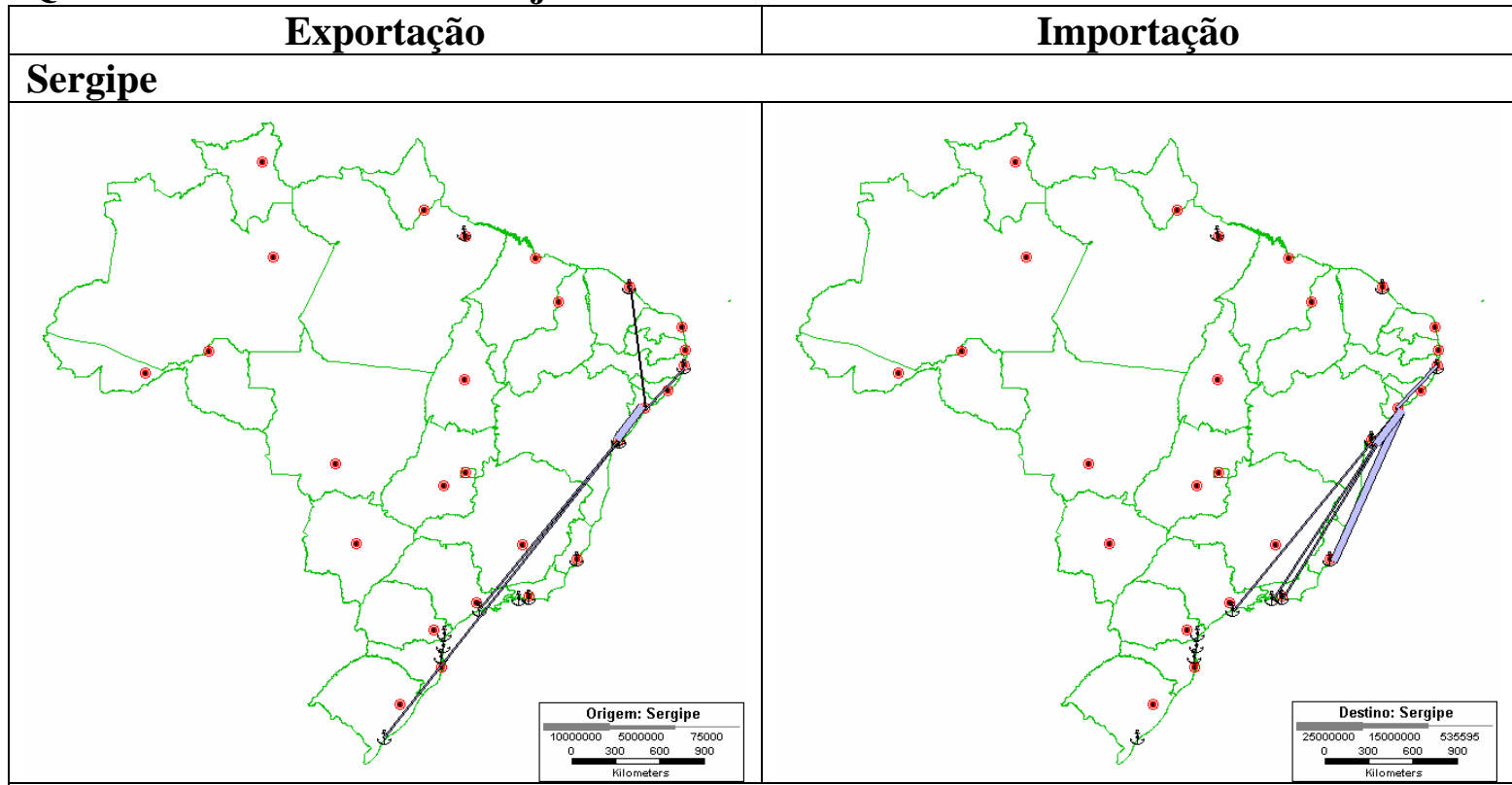

\section{São Paulo}

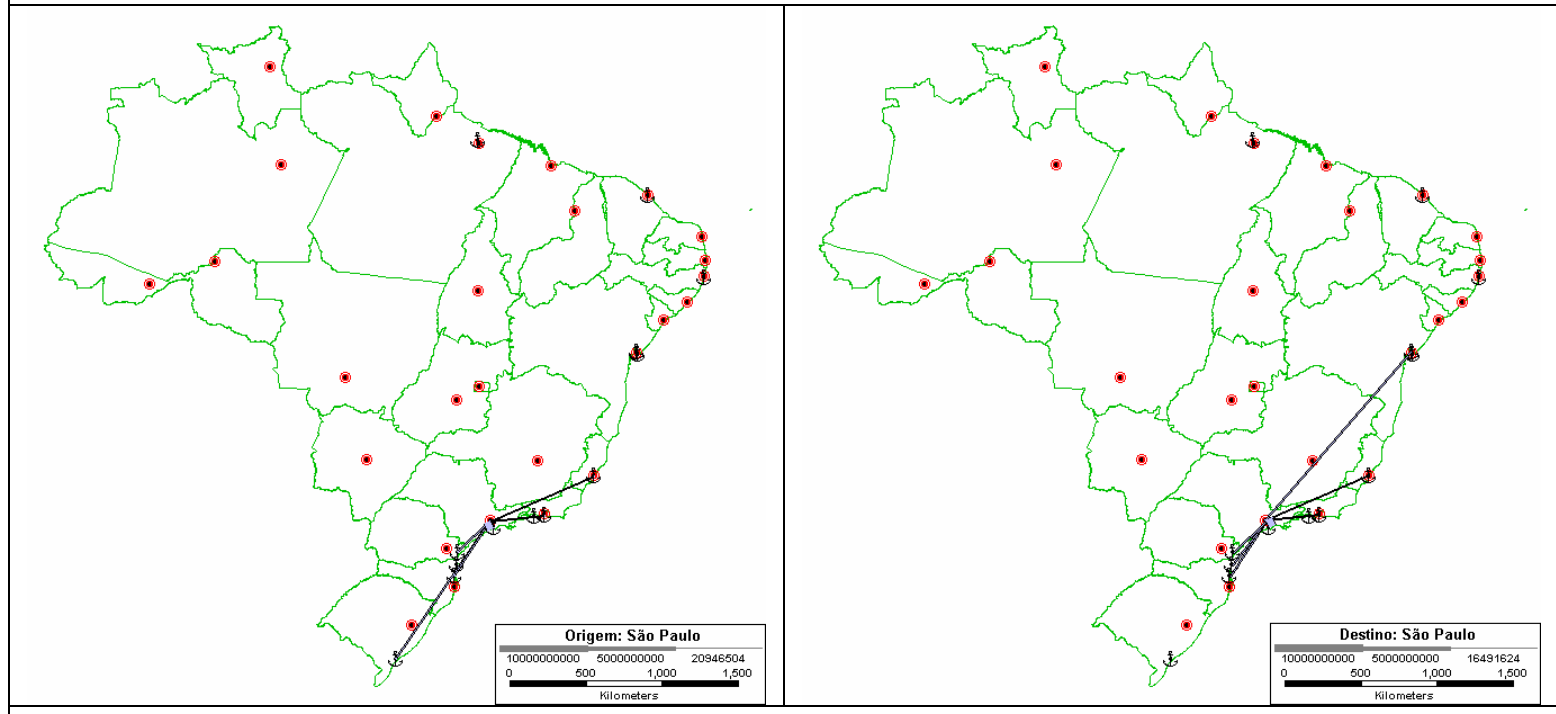

\section{Tocantins}
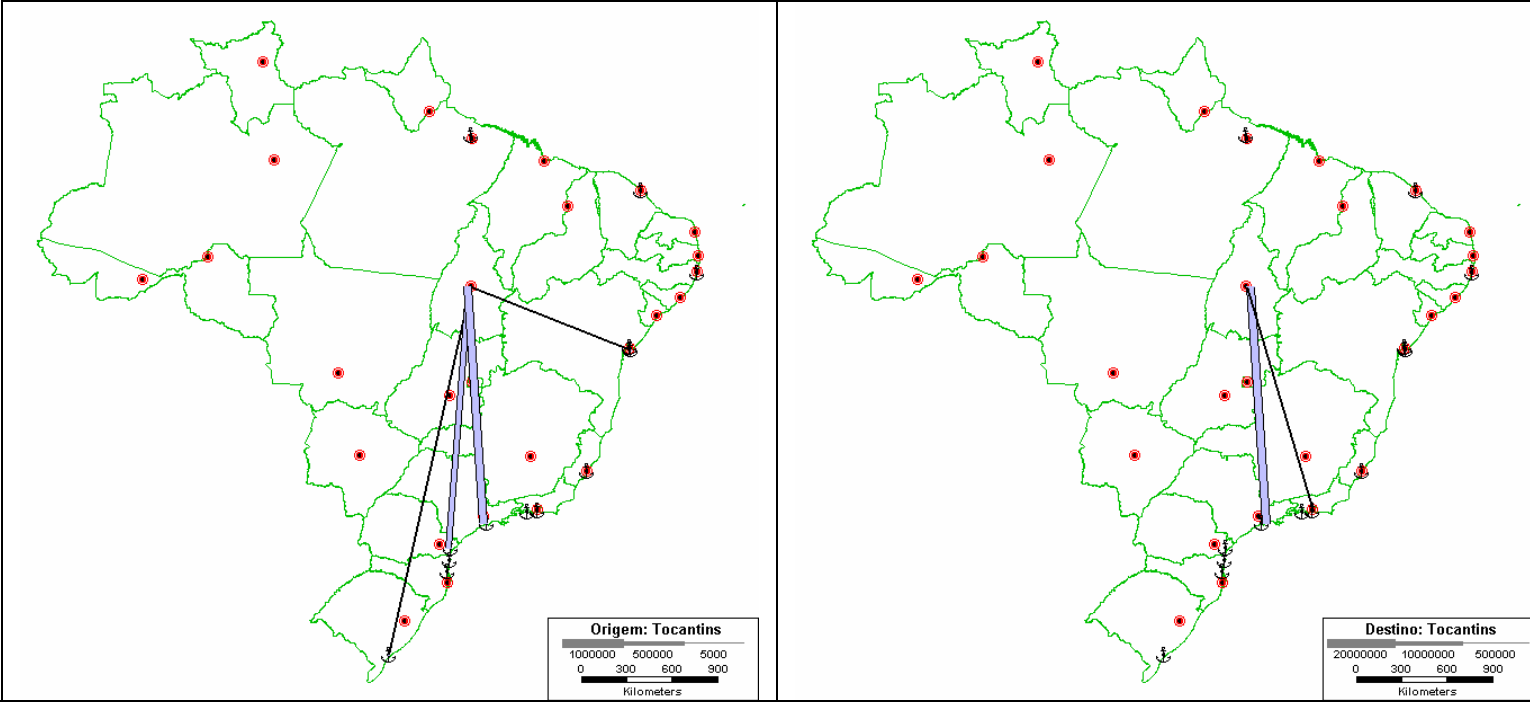

Fonte: MDIC, Aliceweb. 
Tabela A.2.1 - Utilização dos portos pelos estados do Brasil, importações, 2002 (\%)

\begin{tabular}{|c|c|c|c|c|c|c|c|c|c|c|c|c|c|c|}
\hline UF & Aratu & Belém & Fortaleza & Itajaí & Paranaguá & $\begin{array}{l}\text { Rio de } \\
\text { Janeiro }\end{array}$ & Rio Grande & Salvador & Santos & $\begin{array}{c}\text { São } \\
\text { Francisco } \\
\text { do Sul }\end{array}$ & Sepetiba & Suape & Vitória & Total \\
\hline$\overline{\mathrm{ACRE}}$ & 0,00 & 0,00 & 0,00 & 0,00 & 69,91 & 0,00 & 0,00 & 0,00 & 4,96 & 0,00 & 0,00 & $\frac{0,00}{0,00}$ & 0,00 & 74,87 \\
\hline ALAGOAS & 0,00 & 0,00 & 0,06 & 0,00 & 0,18 & 0,45 & 0,00 & 1,68 & 5,35 & 0,00 & 0,00 & 1,03 & 42,92 & 51,67 \\
\hline AMAPA & 0,00 & 8,24 & 0,00 & 0,00 & 0,00 & 0,20 & 0,00 & 0,00 & 6,09 & 0,00 & 0,00 & 0,00 & 0,00 & 14,53 \\
\hline AMAZONAS & 0,00 & 0,00 & 0,00 & 0,00 & 0,12 & 0,12 & 0,00 & 0,00 & 0,03 & 0,02 & 0,03 & 0,00 & 0,00 & 0,32 \\
\hline BAHIA & 36,94 & 0,00 & 0,00 & 0,01 & 0,02 & 0,36 & 0,04 & 44,68 & 1,79 & 0,01 & 0,02 & 0,03 & 1,20 & 85,09 \\
\hline CEARA & 0,00 & 0,00 & 88,98 & 0,01 & 0,00 & 0,02 & 0,12 & 0,01 & 0,52 & 0,00 & 0,00 & 1,05 & 3,88 & 94,58 \\
\hline DISTRITO FEDERAL & 0,00 & 0,25 & 0,01 & 0,13 & 1,68 & 5,16 & 0,25 & 0,14 & 17,20 & 1,40 & 0,91 & 0,03 & 0,63 & 27,78 \\
\hline ESPIRITO SANTO & 0,01 & 0,00 & 0,00 & 0,21 & 0,07 & 3,91 & 0,00 & 0,16 & 1,58 & 0,05 & 0,08 & 0,00 & 76,89 & 82,95 \\
\hline GOIAS & 0,00 & 0,00 & 0,00 & 0,49 & 13,84 & $\begin{array}{l}1,99 \\
1,99\end{array}$ & 0,03 & 0,03 & $\begin{array}{r}1,00 \\
42,81\end{array}$ & 0,64 & 0,02 & 0,01 & 20,42 & 80,29 \\
\hline MARANHAO & 0,00 & 4,13 & 0,85 & 0,00 & 0,00 & 0,05 & 0,00 & 0,00 & 0,01 & 0,00 & 0,00 & 0,11 & 0,07 & 5,21 \\
\hline MATO GROSSO & 0,00 & 0 & $\begin{array}{l}0,03 \\
0,00\end{array}$ & 0,14 & 41,26 & 0,30 & 7,60 & 0,00 & 9,51 & 5,15 & 0,00 & 0,00 & 0,84 & $\begin{array}{r}5,21 \\
64,80\end{array}$ \\
\hline MATO GROSSO DO SUL & 0,00 & 0,00 & 0,00 & 0,38 & 2,57 & 0,57 & 0,00 & 0,00 & 13,33 & 0,00 & 0,37 & 0,00 & 0,12 & 17,34 \\
\hline MINAS GERAIS & 0,00 & 0,00 & 0,02 & 0,58 & 0,50 & 27,81 & 0,04 & 0,21 & 18,95 & 0,01 & 4,01 & 0,00 & 28,54 & 80,67 \\
\hline $\begin{array}{l}\text { PARA } \\
\text { PATAIO }\end{array}$ & 0,00 & 52,71 & 0,13 & 0,00 & 0,00 & $\left.\begin{array}{c}2,01 \\
0,81\end{array}\right)$ & 0,13 & 0,19 & 0,79 & 0,01 & $\begin{array}{l}4,01 \\
0,09\end{array}$ & 0,01 & $\begin{array}{l}20,04 \\
0,05\end{array}$ & 54,93 \\
\hline PARAIBA & 0,00 & 0,00 & 0,21 & 0,00 & 0,00 & 0,00 & 0,59 & 0,30 & 1,14 & 0,00 & 0,00 & 24,15 & 2,38 & 28,77 \\
\hline PARANA & 0,00 & 0,00 & 0,00 & 1,08 & 59,10 & 0,20 & 0,50 & 0,00 & 5,10 & 9,70 & 0,02 & 0,00 & 0,10 & 75,80 \\
\hline PERNAMBUCO & 3,37 & 0,00 & 0,08 & 0,01 & 0,24 & 0,25 & 0,01 & 0,22 & 1,87 & 0,00 & 0,00 & 68,78 & 0,14 & 74,99 \\
\hline PIAUI & 0,00 & 0,00 & 41,69 & 0,00 & 0,00 & 0,39 & 0,00 & 29,99 & 0,00 & 0,00 & 0,00 & 0,31 & 0,00 & 72,38 \\
\hline RIO DE JANEIRO & 0,00 & 0,00 & $\begin{array}{l}4,00 \\
0,00\end{array}$ & 0,07 & 0,26 & 32,59 & 0,05 & 0,00 & 2,68 & 0,00 & 32,84 & 0,01 & 0,45 & 68,95 \\
\hline RIO GRANDE DO NORTE & 0,00 & 0,00 & 5,66 & 0,00 & 0,00 & 0,24 & 0,00 & 2,99 & 15,92 & 0,00 & 0,02 & 17,09 & 26,15 & 68,07 \\
\hline $\begin{array}{l}\text { RIO GRANDE DO SUL } \\
\text { RRA }\end{array}$ & 0,00 & 0,00 & 0,00 & 0,48 & 0,28 & 0,39 & 37,09 & $\begin{array}{l}2,99 \\
0,00\end{array}$ & 4,49 & 0,24 & 0,00 & 0,00 & $\begin{array}{l}20,10 \\
0,01\end{array}$ & $\begin{array}{l}00,01 \\
42,99\end{array}$ \\
\hline RONDONIA & 0,00 & 0,00 & 0,00 & 0,00 & 0,32 & 0,00 & 0,00 & 0,00 & 0,22 & 0,11 & 7,13 & 0,00 & 0,00 & 7,78 \\
\hline RORAIMA & 0,00 & 0,00 & 0,00 & 0,00 & 0,00 & 0,00 & 0,00 & 0,00 & 0,00 & 0,00 & 0,00 & 0,00 & 0,00 & 0,00 \\
\hline SANTA CATARINA & 0,00 & 0,00 & 0,00 & 41,44 & 3,58 & 0,55 & 1,03 & 0,04 & 1,28 & 19,42 & 0,00 & 0,00 & 0,33 & 67,67 \\
\hline SAO PAULO & 0,08 & 0,01 & 0,00 & 0,26 & 0,50 & 0,85 & 0,05 & 0,02 & 51,76 & 0,12 & 0,11 & 0,01 & 0,22 & 54,01 \\
\hline SERGIPE & 0,00 & 0,00 & 0,00 & 0,00 & 0,00 & 2,44 & 0,00 & 22,86 & 5,10 & 0,00 & 0,53 & 10,70 & 22,68 & 64,32 \\
\hline TOCANTINS & 0,00 & 0,00 & 0,00 & 0,00 & 0,00 & 1,94 & 0,00 & 0,00 & 81,12 & 0,00 & 0,00 & 0,00 & 0,00 & 83,07 \\
\hline
\end{tabular}

Fonte: Aliceweb. MDIC. 
Tabela A.2.2 - Utilização dos portos pelos estados do Brasil, exportações, 2002 (\%)

\begin{tabular}{|c|c|c|c|c|c|c|c|c|c|c|c|c|c|c|}
\hline UF & Aratu & Belém & Fortaleza & Itajaí & Paranaguá & $\begin{array}{l}\text { Rio de } \\
\text { Janeiro }\end{array}$ & Rio Grande & Salvador & Santos & $\begin{array}{c}\text { São } \\
\text { Francisco } \\
\text { do Sul }\end{array}$ & Sepetiba & Suape & Vitória & Total \\
\hline$\overline{\mathrm{ACRE}}$ & 0,00 & 0,39 & 0,00 & 57,36 & 24,31 & 0,00 & 6,35 & 0,00 & 0,00 & 1,99 & 0,00 & 0,00 & 0,00 & 90,39 \\
\hline ALAGOAS & 0,00 & 0,00 & 0,30 & 0,00 & 0,00 & 0,00 & 0,00 & 1,71 & 0,19 & 0,00 & 0,00 & 2,29 & 0,01 & 4,50 \\
\hline AMAPA & 0,00 & 5,58 & 0,42 & 0,00 & 0,00 & 1,55 & 0,00 & 0,00 & 0,04 & 0,00 & 0,00 & 0,00 & 0,00 & 7,59 \\
\hline AMAZONAS & 0,00 & 0,09 & 0,00 & 0,04 & 0,05 & 0,60 & 0,00 & 0,12 & 0,65 & 0,00 & 0,00 & 0,02 & 0,00 & 1,56 \\
\hline BAHIA & 28,39 & 0,01 & 0,27 & 0,01 & 0,02 & 0,73 & 0,25 & 47,49 & 1,41 & 0,02 & 0,00 & 0,43 & 8,85 & 87,88 \\
\hline CEARA & 0,00 & 0,04 & 82,02 & 0,00 & 0,00 & 0,04 & 0,68 & 0,02 & 3,76 & 0,00 & 0,00 & 0,57 & 0,08 & 87,19 \\
\hline DISTRITO FEDERAL & 0,00 & 0,00 & 0,00 & 0,20 & 0,00 & 0,15 & 0,00 & 0,00 & 3,58 & 0,00 & 0,00 & 0,00 & 77,09 & 81,01 \\
\hline $\begin{array}{l}\text { ESPIRITO SANTO } \\
\text { SELO }\end{array}$ & 0,00 & 0,00 & 0,00 & 0,00 & 0,01 & 1,07 & 0,00 & 0,09 & 0,15 & 0,00 & 0,08 & 0,00 & 94,66 & 96,07 \\
\hline GOIAS & 0,00 & 0,00 & 0,00 & 5,33 & 7,06 & 0,13 & 0,04 & 0,00 & 40,43 & 1,15 & 0,02 & 0,00 & 29,46 & 83,63 \\
\hline MARANHAO & 0,00 & 2,22 & 0,20 & 0,00 & 0,00 & 0,02 & 0,29 & 0,00 & 0,08 & 0,00 & 0,00 & 0,13 & 0,00 & 2,94 \\
\hline MATO GROSSO & 0,00 & 0,01 & 0,00 & 1,30 & 19,73 & 0,01 & 0,23 & 0,00 & 44,29 & 12,16 & 0,00 & 0,00 & 8,66 & 86,39 \\
\hline MATO GROSSO DO SUL & 0,00 & 0,00 & 0,00 & 18,11 & 24,74 & 0,00 & 0,66 & 0,00 & 24,11 & 15,54 & 0,00 & 0,00 & 0,00 & 83,16 \\
\hline MINAS GERAIS & 0,00 & 0,00 & 0,00 & 0,54 & 0,73 & 20,33 & 0,02 & 0,06 & 18,42 & 0,25 & 10,07 & 0,00 & 41,29 & 91,71 \\
\hline PARA & 0,00 & 18,21 & 0,12 & 0,01 & 0,16 & 0,01 & 0,01 & 0,00 & 0,26 & 0,01 & 0,00 & 0,02 & 0,06 & 18,88 \\
\hline PARAIBA & 0,00 & 0,00 & 26,09 & 0,00 & 0,00 & 0,01 & 0,34 & 0,93 & 3,52 & 0,01 & 0,00 & 35,30 & 0,16 & 66,38 \\
\hline PARANA & 0,00 & 0,00 & 0,00 & 8,93 & 70,26 & 0,25 & 0,50 & 0,00 & 4,11 & 7,44 & 0,01 & 0,00 & 0,02 & 91,52 \\
\hline PERNAMBUCO & 0,00 & 0,06 & 5,46 & 0,00 & 0,00 & 0,10 & 0,38 & 10,96 & 1,69 & 0,00 & 0,00 & 32,08 & 0,01 & 50,75 \\
\hline PIAUI & 0,00 & 0,00 & 71,72 & 0,00 & 0,00 & 0,04 & 0,00 & 2,30 & 0,03 & 0,00 & 0,00 & 0,01 & 0,00 & 74,10 \\
\hline RIO DE JANEIRO & 0,00 & 0,04 & 0,01 & 0,03 & 0,13 & 27,16 & 0,26 & 0,01 & 0,85 & 0,04 & 33,07 & 0,02 & 0,39 & 62,01 \\
\hline RIO GRANDE DO NORTE & 0,00 & 0,00 & 37,76 & 0,00 & 0,00 & 0,01 & 0,00 & 0,13 & 0,19 & 0,00 & 0,00 & 20,51 & 0,03 & 58,63 \\
\hline $\begin{array}{l}\text { RIO GRANDE DO SUL } \\
\text { R }\end{array}$ & 0,00 & 0,01 & 0,25 & 5,05 & 1,04 & 0,10 & 71,28 & 0,01 & 1,82 & 1,58 & 0,01 & 0,00 & 0,00 & 81,14 \\
\hline RONDONIA & 0,00 & 0,78 & 0,00 & 9,16 & 65,75 & 1,82 & 0,04 & 0,00 & 9,96 & 2,81 & 0,00 & 0,00 & 1,46 & 91,79 \\
\hline RORAIMA & 0,00 & 0,00 & 0,00 & 0,00 & 4,72 & 0,00 & 0,00 & 0,00 & 0,00 & 0,00 & 0,00 & 0,00 & 0,45 & 5,17 \\
\hline SANTA CATARINA & 0,00 & 0,00 & 0,00 & 43,72 & 7,40 & 0,02 & 0,30 & 0,00 & 0,58 & 36,14 & 0,00 & 0,00 & 0,01 & 88,17 \\
\hline SAO PAULO & 0,00 & 0,02 & 0,01 & 0,63 & 2,23 & 1,60 & 0,18 & 0,03 & 61,69 & 0,48 & 0,05 & 0,01 & 0,10 & 67,03 \\
\hline SERGIPE & 0,00 & 0,00 & 0,17 & 0,00 & 0,00 & 0,00 & 0,43 & 31,74 & 5,47 & 0,00 & 0,00 & 1,43 & 0,00 & 39,24 \\
\hline TOCANTINS & 0,00 & 0,00 & 0,00 & 0,00 & 4,50 & 0,00 & 0,03 & 0,04 & 6,04 & 0,00 & 0,00 & 0,00 & 0,00 & 10,61 \\
\hline
\end{tabular}

Fonte: Aliceweb. MDIC. 